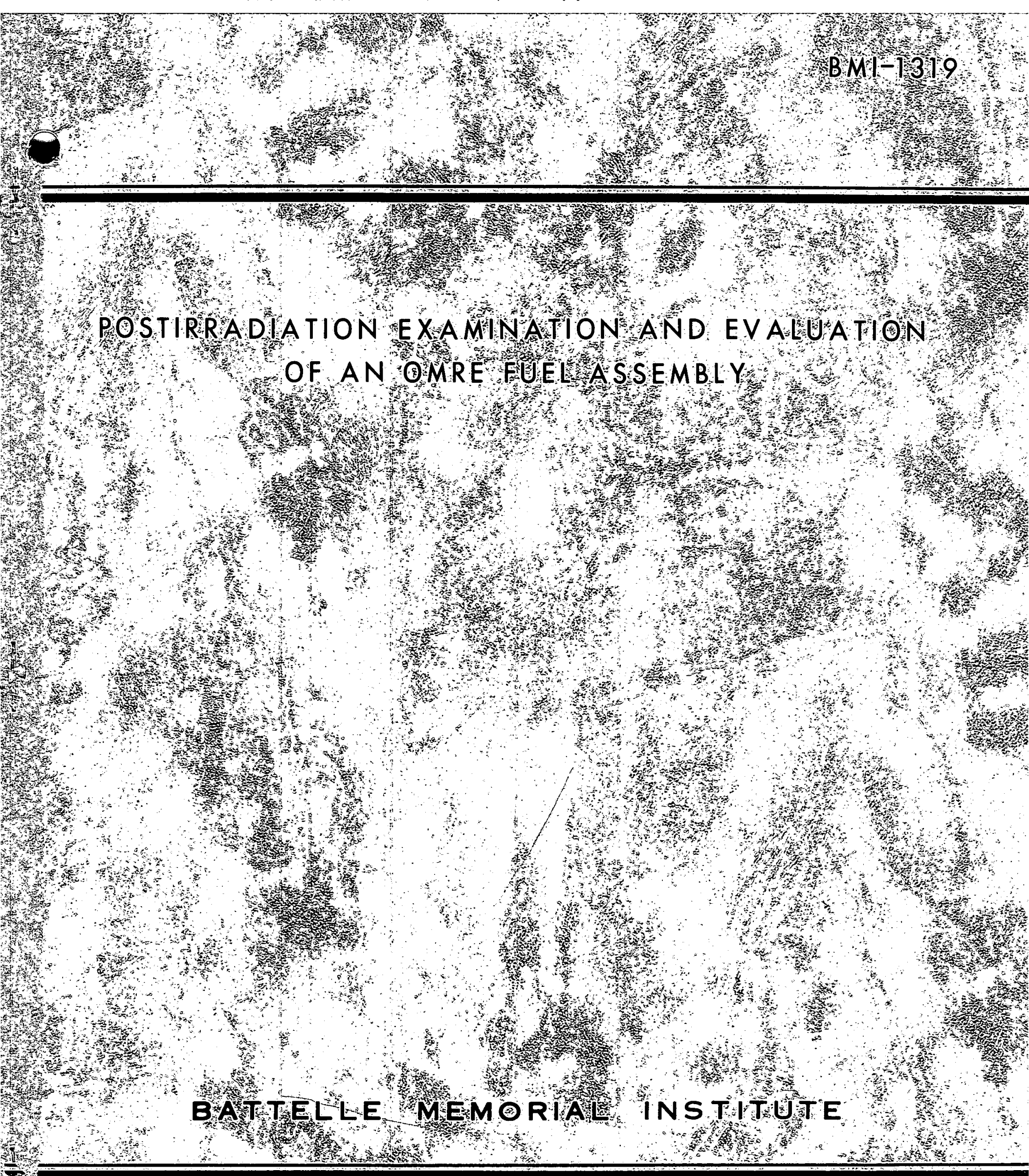




\section{LEGAL NOTICE}

This report was prepared as an account of Government sponsored work. Neither the United States, nor the Commission, nor any person acting on behalf of the Commission:

A. Mokes any warranty or representation, express or implied, with respect to the occuracy, completeness, or usefulness of the information contained in this report, or that the use of any information, opparatus, method, or process disclosed in this report may not infringe privately owned rights; or

B. Assumes any liabilities with respect to the use of, or for damages resulting from the use of any information, apparatus, method, or process disclosed in this report.

As used in the above, "person acting on behalf of the Commission" includes any employee or controctor of the Commission to the extent that such employee or contractor prepores, hondles or distributes, or provides access to, any information pursuant to his employment or contract with the Commission.

Printed in USA

Price $\$ 2.25$

Available from the Office of Technical Services

U. S. Department of Commerce

Washington 25, D. C. 


\section{DISCLAIMER}

This report was prepared as an account of work sponsored by an agency of the United States Government. Neither the United States Government nor any agency Thereof, nor any of their employees, makes any warranty, express or implied, or assumes any legal liability or responsibility for the accuracy, completeness, or usefulness of any information, apparatus, product, or process disclosed, or represents that its use would not infringe privately owned rights. Reference herein to any specific commercial product, process, or service by trade name, trademark, manufacturer, or otherwise does not necessarily constitute or imply its endorsement, recommendation, or favoring by the United States Government or any agency thereof. The views and opinions of authors expressed herein do not necessarily state or reflect those of the United States Government or any agency thereof. 


\section{DISCLAIMER}

Portions of this document may be illegible in electronic image products. Images are produced from the best available original document. 
Report No. BMI-1319

UC-25 Metallurgy and Ceramics (TID-4500, 14th Ed.)

Contract No. W-7405-eng-92

\section{POSTIRRADIATION EXAMINATION AND EVALUATION \\ OF AN OMRE FUEL ASSEMBLY}

by

Richard J. Burian

John E. Gates

February 11, 1959

BATTELLE MEMORIAL INSTITUTE

$505 \mathrm{King}$ Avenue

Columbus 1, Ohio 
ABSTRACT . • . . . . . . . . . . . . . . . . . . . . . 1

INTRODUCTION

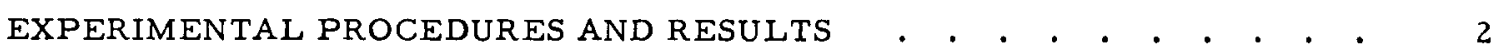

Examination of Fuel-Element Assembly . . . . . . . . . . . . . . . 2

Unloading of the Element From the Shipping Cask . . . . . . 2

Inspection of the Fuel-Element Exterior . . . . . . . . . . 3

Fuel-Element-Box Distortion . . . . . . . . . . . . . . 7

End-Section Removal . . . . . . . . . . . . . . . . 10

Plate-Spacing Measurements . . . . . . . . . . . . . 10

Measurements of the Gamma Radiation Emitted From the Fuel

Element . . . . . . . . . . . . . . . . . . . 15

Examination of Fuel Plates and Interior of the Fuel-Element Box . . $\quad 15$

Inspection of the Fuel Plates . . . . . . . . . . . . . 23

Inspection of the Fuel-Element-Box Interior . . . . . . . : 25

Fuel-Plate Temperature Measurements . . • . . . . . . 25

Gamma-Activity Scans of Fuel Plates . . . . . . . . . . 25

Radiochemical Burnup Analyses and Correlation With Gamma-Scan

Data . . . . . . . . . . . . . . . . . . . . . 42

Measurements of Fuel-Plate and Organic-Residue Thicknesses . . 44

Collection of the Organic Residue . . . . . . . . . . . . 46

Metallographic Examination . . . . . . . . . . . . . 47

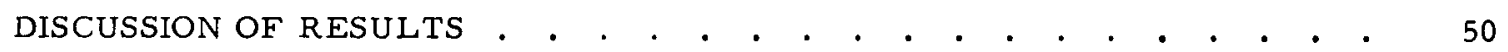

EVALUATION

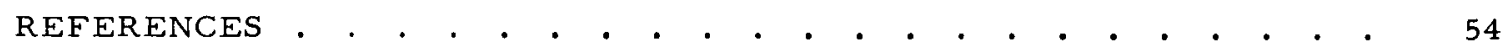

APPENDIX A

CASK-HANDLING METHODS . . . . . . . . . . . . . . . . . A-l

APPENDIX B

TEMPERATURE MEASUREMENTS OF THE FUEL-ELEMENT-BOX ASSEMBLY

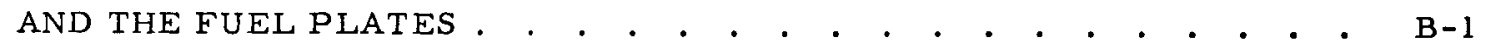

APPENDIX C

REMOVAL OF CARBONACEOUS RESIDUE FROM THE FUEL-ELEMENT-BOX ASSEMBLY AND FUEL PLATES

APPENDIX D

URANIUM BURNUP ANALYSIS.

\section{APPENDIX E}

METHOD OF EVALUATING AVERAGE FUEL-PLATE BURNUP . . . . . E-I 


\title{
POSTIRRADIATION EXAMINATION AND EVALUATION OF AN OMRE FUEL ASSEMBLY
}

\author{
Richard J. Burian and John E. Gares
}

\begin{abstract}
A fuel-element assembly from the first loading of the OMRE was examined in detail after experiencing an average uranium burnup of between 1 and $2 a / o$. The rate of decay heat generation was evaluated by temperature monitoring of the shippingcask coolant. Temperatures of the fuel-element-box assembly and the fuel plates were measured with thermocouples and Tempilstils. Structurally, the fuel-element assembly was affected very little by either radiation or the organic coolant-moderator. Although there was some distortion in the side and end plates of the assembly, the coolant channels between the fuel plates were free from major fouling and obstructions. The channel cross sections were reduced at specific points less than 5 per cent.

Common machine-shop tools, adapted for remote operation, were used to disassemble the element. A layer of residue from the degradation of the organic coolant was deposited over the fuel plates. This was tenacious and could be removed only by buffing with a wire wheel. The only defects noticed on the surface of the fuel plates were a series of pits on one plate. These extended about two-thirds of the way through the cladding and are thought to have been formed during fabrication. A metallographic examination performed in the region of the pits revealed chemical attack had not caused the pitting.
\end{abstract}

The plates studied were subjected to complete gamma scanning. Specimens removed from selected areas of the scanned plates were radiochemically analyzed for burnup and the results correlated with the gamma-scan data. Burnup profiles were constructed for each of the scanned plates. The gamma-scan data were also utilized to determine the average plate burnup.

\section{INTRODUCTION}

Atomics International, a Division of North American Aviation, Inc., has been investigating the feasibility of a power-reactor concept involving the use of a hydrocarbon as a moderator and coolant. This program, called the Organic Moderated Reactor Experiment, was specifically designed to show by actual operation of a reactor experiment, that certain hydrocarbons are sufficiently stable under exposure to high radiation fluxes and high temperatures for use in a power reactor.

The fuel used in the first loading of the OMRE is nominally $25 \mathrm{w} / \mathrm{o}$ of fully enriched $\mathrm{UO}_{2}$ uniformly dispersed in a matrix of Type 304 stainless steel. The fuel plates were fabricated by Atomics International to give over-all dimensions of 0.03 by 2.8 by $38 \mathrm{in.}$ The fueled core was nominally $0.020 \mathrm{in.} \mathrm{thick} \mathrm{and} \mathrm{had} \mathrm{a} \mathrm{0.005-in.} \mathrm{cladding.}$ Sixteen of these plates were arranged in a box-type fuel-element assembly. A complete description of the fabrication and assembly techniques is given in a report $(1)$ by Atomics International. The coolant and moderator is a mixture mainly of or tho- and metaterphenyl, commonly known by its trade name of Santowax OM. This material is fully described in another report by Atomics International. (2)

The OMRE was brought to criticality on September 17, 1957. A description of the

$E$ design and initial operation is given in NAA-SR-2400.'(2) Sufficient operating

(1) References at end of text. 
time had been accumulated by early 1958 to warrant the removal of one fuel element for examination. Consequently, Element OMRE-3 was removed during a shutdown in June, 1958 , and Battelle was requested to perform the postirradiation examination of this fuel element.

The selected fuel element was shipped to Battelle in a special shipping cask provided by AI. It arrived at the Battelle Hot-Cell Facility during July, 1958. The examination of the element was begun shortly after its receipt. This report describes the results of this examination and the remote handling techniques which were used in order to obtain the data.

\section{EXPERIMENTAL PROCEDURES AND RESULTS}

The examination of Element OMRE-3 was divided into two phases covering (1) the examination of the fuel-element as sembly, and (2) the examination of the fuel plates. Each of these phases is described separately below.

\section{Examination of the Fuel-Element Assembly}

The examination of the fuel-element assembly included taking photographs, making visual inspections for fouling and other defects, measurements of twist and warpage in the fuel-element box, a scan of the gamma activity as a function of box length, measurements of the exterior dimensions of the box, temperature measurements, and platespacing measurements. Since similar fuel elements will no doubt be examined in the future by other laboratories, remote handling techniques used in the examinations are described in more than usual detail in the Appendixes.

Unloading of the Fuel Element From the Shipping Cask

The fuel element was trucked to Battelle in a special cask designed by AI. During shipment, the radioactive decay heat from the fuel element was removed by immersion of the element in diphenyl. The heat was removed from the diphenyl by a circulating water system powered by a pump mounted on the truck. Once the element was removed from the cask, however, it was considered possible that the heat from radioactive decay might become a problem since such heat would then have to be dissipated by air convection. It was desired that the fuel-plate temperatures not be allowed to exceed about $300 \mathrm{~F}$ during handling in order to a void complicating the evaluation of the results of the examination. Measurements of the cask coolant temperatures indicated that there should not be any particular problems with high temperatures in the fuel plates during in-cell handling. The temperature measurements and the cask unloading are described in Appendix A.

The fuel element was remotely unloaded from the shipping cask approximately $24 \mathrm{hr}$ after the diphenyl coolant was drained from the cask. The delay in unloading was due to a malfunction in the lid-actuating system incorporated in the cask, as described in Appendix A. 
The fuel element is shown in Figure 1 as it was removed from the shipping cask. Part of the organic residue adhering to the outside of the element appeared to have been partly removed, especially over areas adjacent to the fueled portion of the plates and around the tabs. The residue appeared to be more brittle and less adherent in these areas. The coolant evaporated rapidly from the center portions of the fuel box while wisps of vapor were observed emanating from the elevated end of the fuel element. This caused some concern about overheating of the fuel plates and temperature measurements were begun immediately.

Temperature measurements were performed at various times during the first few days of in-cell handling and storage. These are outlined in detail in Appendix B. The measurements indicated that the temperature of the side plate of the fuel-element box was greater than $150 \mathrm{~F}$ but less than $200 \mathrm{~F}$ in regions near the center. The exterior temperature of the remainder of the fuel element was below $150 \mathrm{~F}$. The measurements indicated that free-air convection was sufficient to keep the fuel-plate temperatures below $300 \mathrm{~F}$. However, the fuel element had to be stored in essentially stagnant air in a brass can while in the cell.

In order to avoid any possibility of overheating the plates during storage, the storage can was filled with water, since adequate quantities of diphenyl were not immediately available. Figure 2 shows the fuel element 3 days after storage in the water. The white material around the fuel-element box at the top of the picture was the result of water evaporation.

\section{Inspection of the Fuel-Element Exterior}

The fuel element was inspected visually for obvious failures or defects at the time it was removed from the cask. The general structural appearance was good and the element was observed to be quite rigid. All of the tabs protruding through the side plates of the fuel-element-box assembly were in place. The spring-actuated locking mechanism appeared to be undamaged. There were no signs of major deposits of organic residues or other crud which could have affected the flow of coolant through the element. As can be seen in Figure 3, the small passage through the upper-end section was open.

The intensity of the radiation emitted from the element 3 days after receipt was $10,000 \mathrm{r}$ per $\mathrm{hr}$ at a distance of $5 \mathrm{ft}$. The measurement was made with a Jordan Model AGB-10K-SR survey meter. Attempts to remove the organic residue deposited on the element met with varying degrees of success. The residue could be dissolved and wiped from areas near the center of the fuel element, as shown in Figure 4. Only one surface of the fuel element is visible in this photograph because the element is resting in the trough used to collect the solvents employed in the cleaning operation. It appeared that the major portion of the residue in these areas had come off prior to removal of the element from the cask, leaving only a thin, "sooty" type of deposit. The heavier deposits were almost impossible to remove by ordinary techniques, as described in Appendix C. As is mentioned, steel wire brushing produced the best results. After the attempts to remove the organic residue were discontinued, the element was examined macroscopically.

The fuel element was examined at magnifications to $32 \mathrm{X}$ with the aid of a stereomacroscope. Macrophotographs were made of representative areas of the exterior 


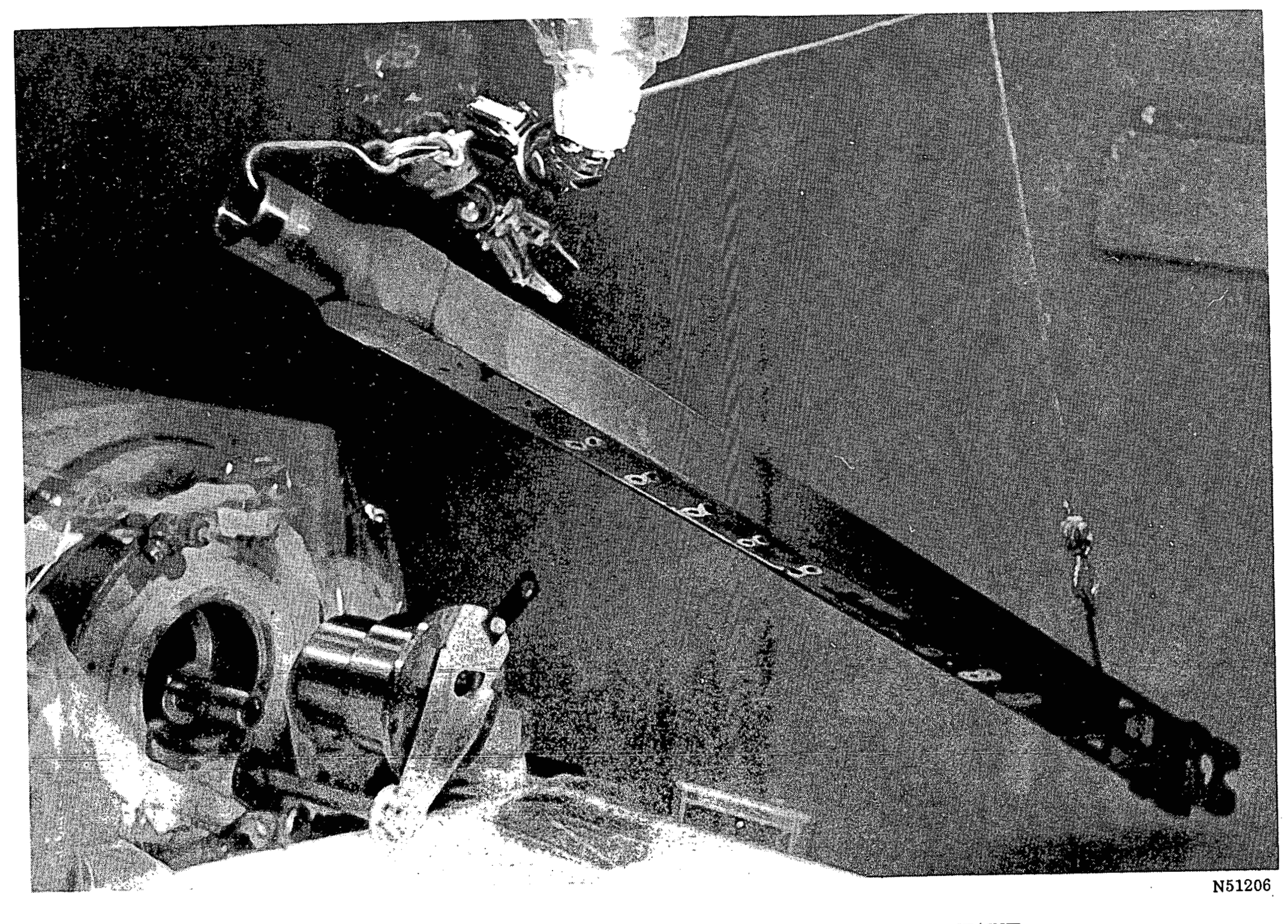

FIGURE 1. ELEMENT OMRE-3 AS IT WAS UNLOADED FROM THE SHIPPING CONTAINER

Note the areas around the tabs where the residue apparently was removed. 


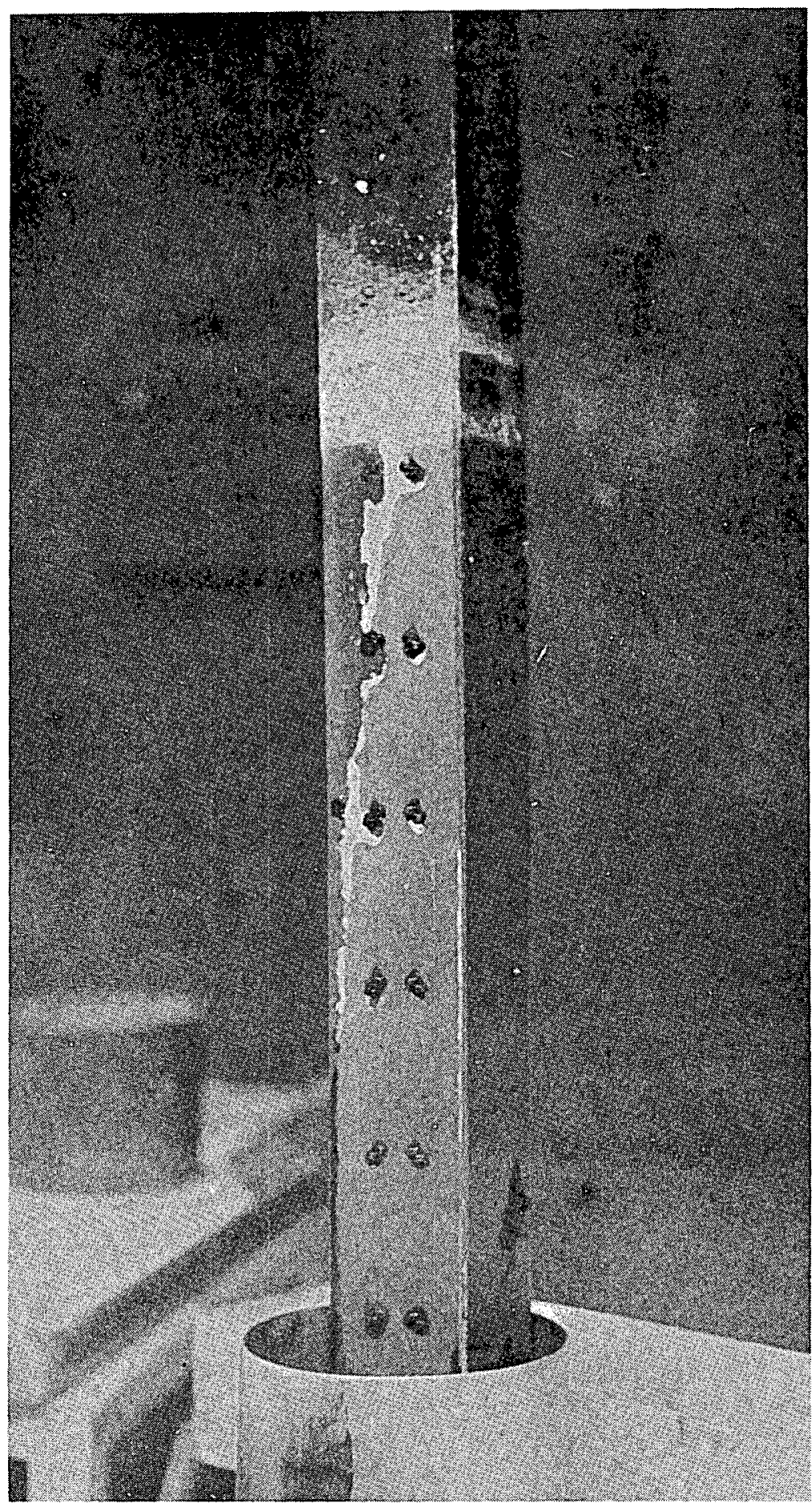

N51447

FIGURE 2. A PORTION OF THE FUEL-ELEMENT-BOX ASSEMBLY AS IT WAS REMOVED FROM THE STORAGE CAN

Note the areas from which the organic residue had disappeared. 


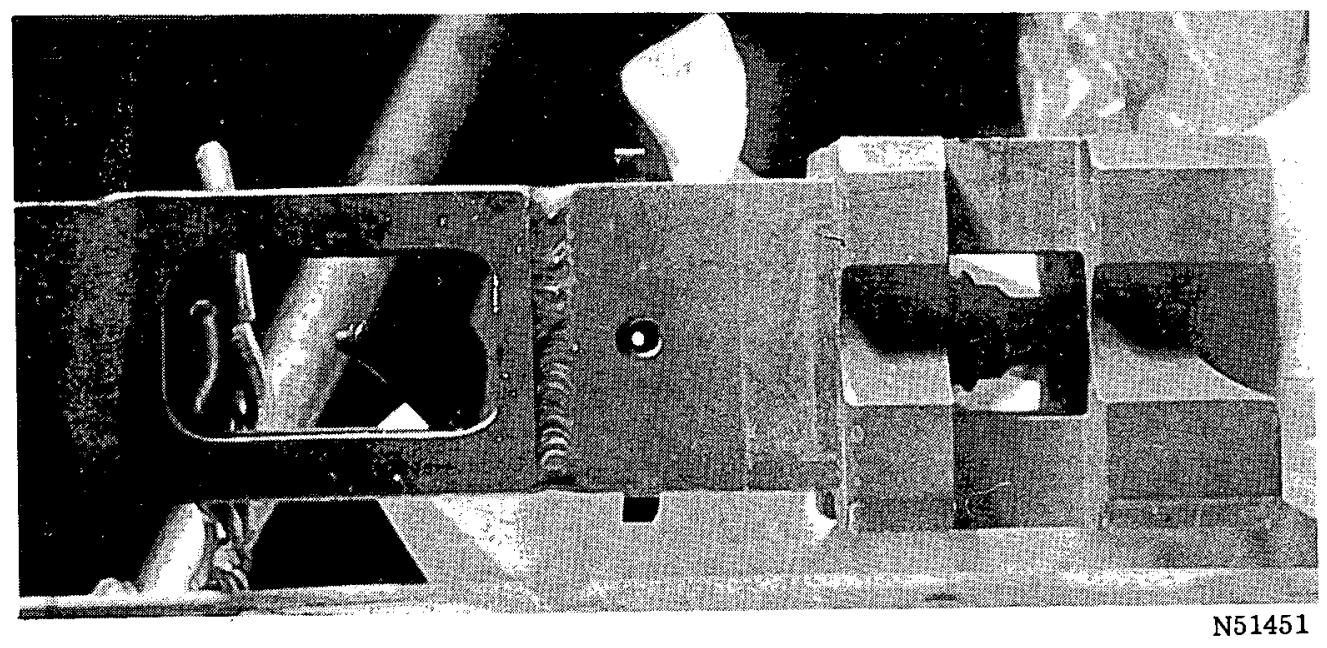

FIGURE 3. THE TOP END SECTION AND DIVERTER OF THE FUEL ELEMENT

Note the protruding latches and the open coolant passage.

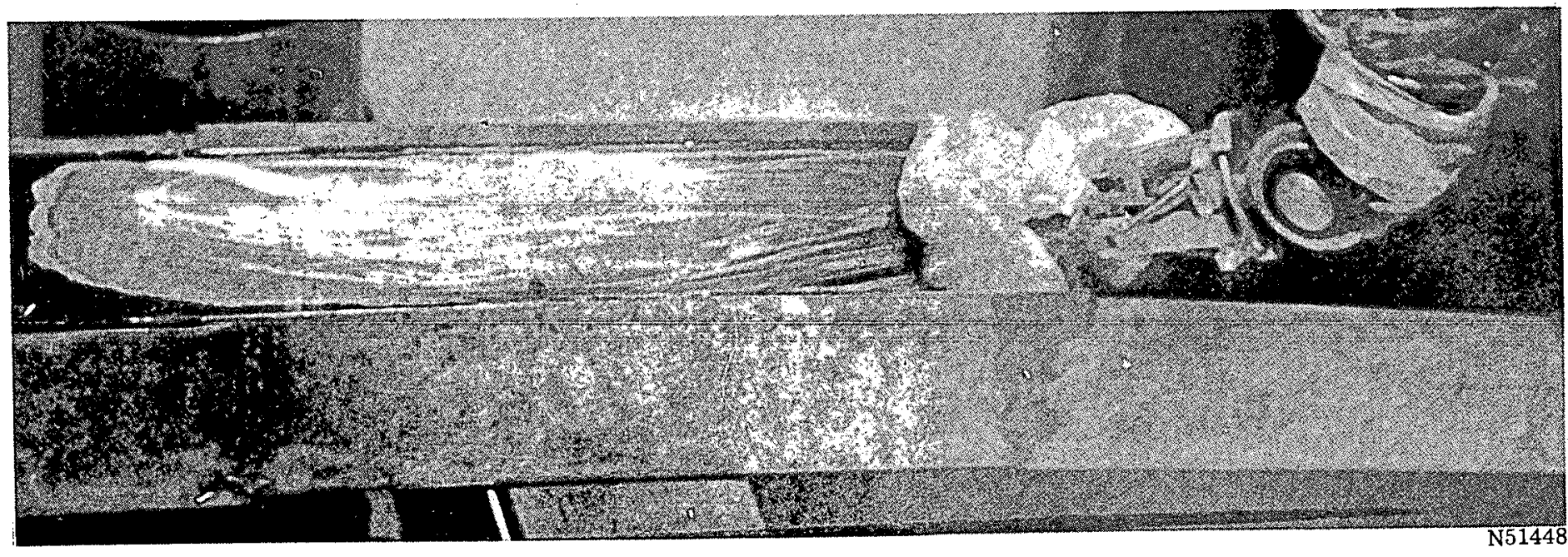

FIGURE 4. AN AREA ON ONE SURFACE OF THE ELEMENT DURING CLEANING IN A TROUGH

The residue was easily wiped from this area, probably because most of the residue had come off prior to removal from the cask. 
surface of the fuel-element box. Figure 5 shows a scratch made in the organic residue. The chipped edge of the scratch mark indicates the brittleness and adherence qualities of the residue. Some areas of the residue were also apparently blistered. When these areas were scraped, the blisters were removed, leaving the surface appearance shown in Figure 6. Examination of the welds at each corner and end of the fuel-element box indicated no evidence of corrosion. Figure 7 shows a representative area of the corner welds at a magnification of $12 X$. The light spots are areas where small chips of the orginic residue were knocked off, revealing bare metal. The only apparent defect in any of the welds was a fine, hairline crack. This crack extended about one-third the width of the weld bead, but did not penetrate deep enough to be reason for concern. Due to the nature of the surface, a satisfactory photograph of this area could not be obtained.

Fuel-Element-Box Distortion

Distortion of the fuel-element box was measured by the use of specially designed equipment. This equipment consisted of a linear variable differential transformer (LVDT) mounted on a lathe bed.

A 9-in. lathe with a bed $60 \mathrm{in.}$ long was used as the base of the machine. The original head and tail stocks were removed and new support blocks were installed to hold the fuel element parallel with the lathe bed. The LVDT was mounted in a milling attachment which replaced the tool-post holder on the lathe cross-compound. This enabled the LVDT to be moved in three dimensions. The axis of the LVDT was horizontal and in operation the spring-loaded plunger followed the profile of the vertical side of the fuel-element-box assembly. By scanning the vertical plane rather than the horizontal, deflection in the element due to beam effects was not recorded by the LVDT. The carriage of the lathe was driven by the lead screw which was powered by a reversible ratiomotor. A cam on the lead screw triggered a microswitch upon each revolution. The signal from the microswitch was fed into the timing channel of a two-channel Sanborn-150 recorder. The LVDT signal was also recorded on this instrument. Since the lead screw had 8-pitch threads, the distance between consecutive timing marks on the strip chart signified $1 / 8$ in. of carriage travel. The accuracy of the LVDT and recorder system was estimated to be within 0.0002 in.

Three longitudinal profile scans were made on each end plate, one along the center line and one approximately $3 / 4 \mathrm{in}$. to either side of the center line. One longitudinal profile scan was made on each side plate along the center line. Transverse scans were also made on each side of the element in the region of the first and twelfth tabs from the bottom of the element. Before these profile scans could be assembled to represent the profile of the element, it was necessary to measure the width of the fuel-element box.

The measurements of the width of the fuel-element-box assembly were made with a flat-anvil micrometer caliper. Three width measurements were made on lines through two sets of tabs and adjacent to the welds at each end of the fuel-element box. The tabs were numbered from the bottom of the element. Table 1 lists the results of these measurements. A diagram of the element is shown in Figure 8 that will assist in orienting the measurement locations. With the completion of the element-box width measurements, it was possible to assemble the individual profile scans into one complete profile picture. 

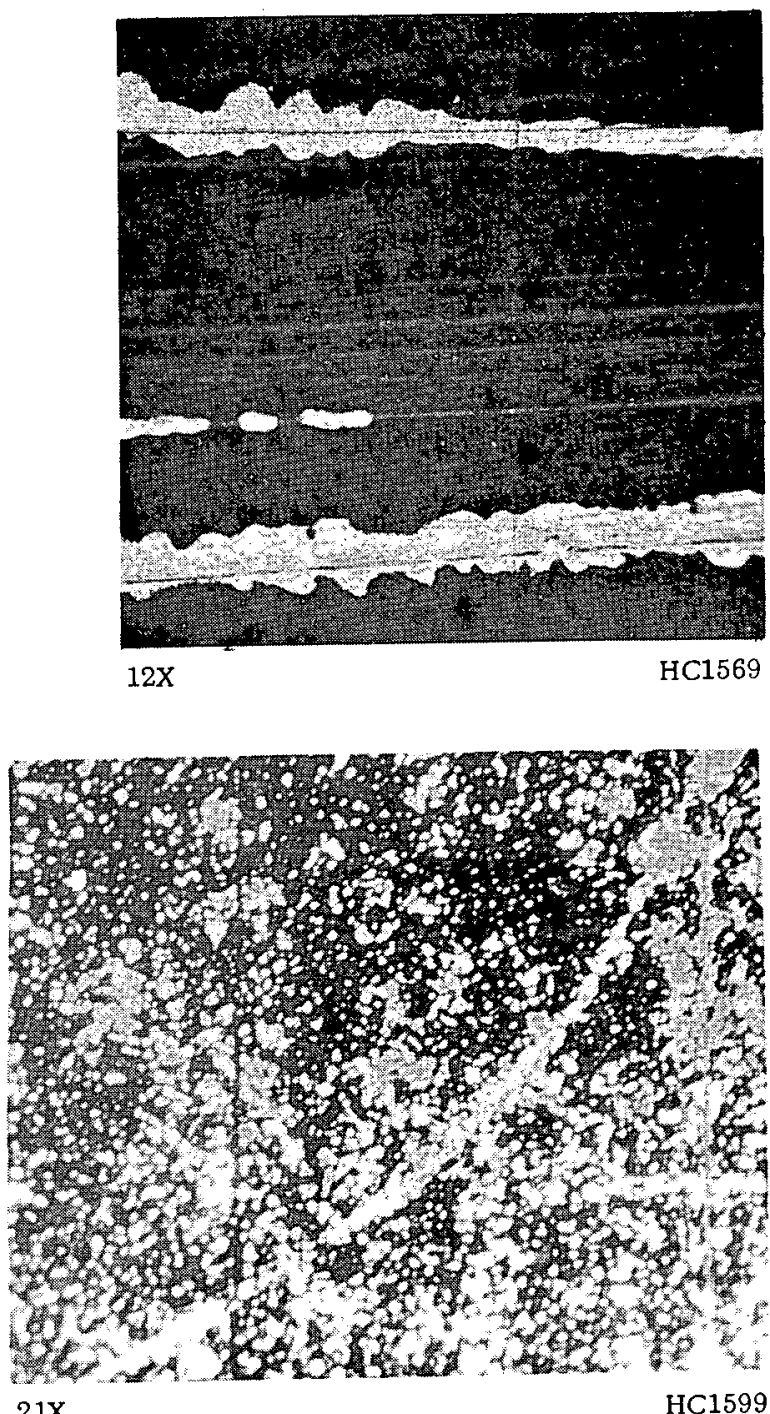

$21 \mathrm{X}$

HC1599

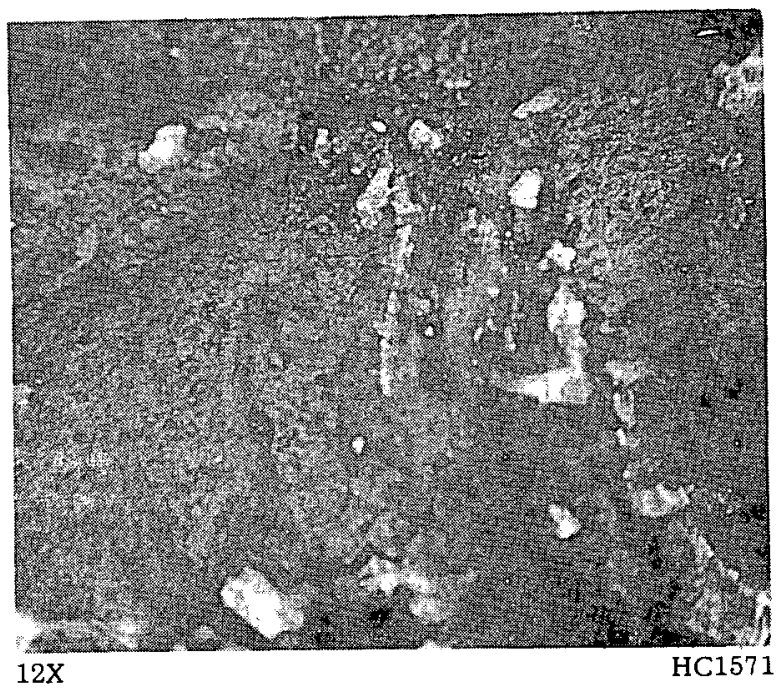

FIGURE 5. SCRA TCHES ACROSS AN AREA OF A SIDE PLATE OF THE FUEL-ELEMENT BOX

Note that the black deposit is dislodged only in the immediate area of the scratches.
FIGURE 6. SURFACE OF A SIDE PLATE OF THE FUELELEMENT BOX WHICH HAD BEEN LIGHTLY SCRAPED

Small blisters in the organic residue were knocked off, exposing bare metal.
FIGURE 7. A REPRESENTA TIVE AREA OF A CORNER WELD Small chips of the organic residue have been knocked off. 


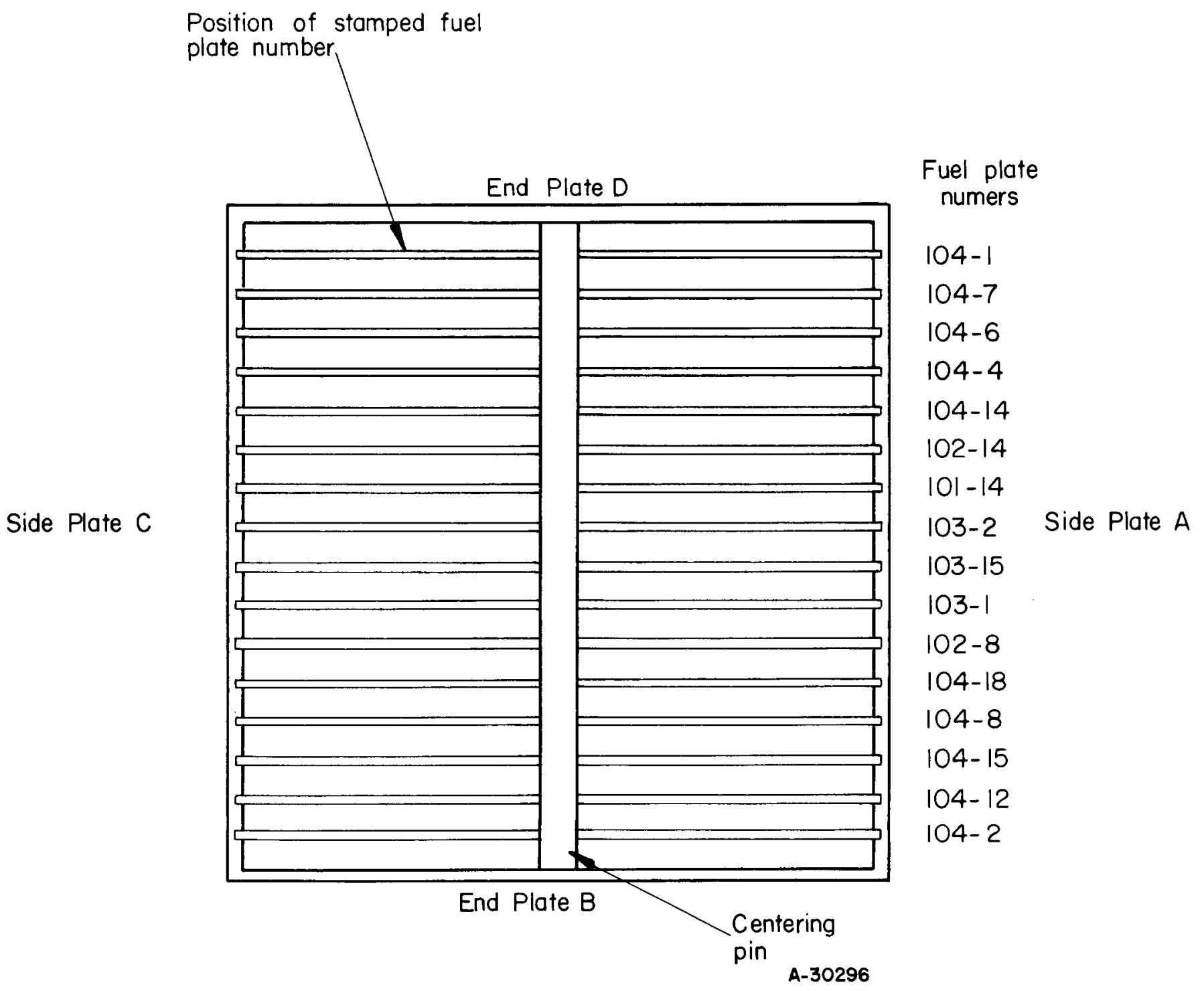

FIGURE 8. BOTTOM END OF ELEMENT OMRE - 3

This diagram illustrates the orientation notation employed for measurements. 
TABLE 1. WIDTH MEASUREMENTS OF OMRE-3 FUEL-ELEMENTBOX ASSEMBLY

\begin{tabular}{ccccccc}
\hline \multirow{2}{*}{$\begin{array}{c}\text { Location of } \\
\text { Measurement (a) }\end{array}$} & \multicolumn{3}{c}{ Width at Indicated Position Along Length of Box Assembly (b), in. } \\
\cline { 2 - 7 } & Bottom Weld & Tab l & Tab 2 & Tab 11 & Tab 12 & Top Weld \\
\hline B-D, A & 2.864 & 2.823 & 2.812 & 2.814 & 2.809 & 2.842 \\
B-D, M & 2.862 & 2.801 & 2.793 & 2.786 & 2.792 & 2.857 \\
B-D, C & 2.868 & 2.811 & 2.791 & 2.810 & 2.826 & 2.859 \\
A-C, B & 2.809 & 2.803 & 2.799 & 2.812 & 2.817 & 2.822 \\
A-C, M & 2.826 & 2.805 & 2.810 & 2.812 & 2.808 & 2.819 \\
A-C, D & 2.809 & 2.805 & 2.805 & 2.804 & 2.800 & 2.812 \\
& & & & & &
\end{tabular}

(a) Except for $M$, the letters identify fuel-element-box plates and indicate the location of the box-width measurement. Thus, $B-D, A$ indicates a width measurement across plates $B$ and $D$, about $3 / 4$ in. from the plate center line toward Plate A. The letter $M$ indicates a measurement on the plate center line.

(b) The tabs are numbered from the bottom weld.

The profile pictures are shown in Figures 9, 10, and 11 . Figures 9 and 10 show the longitudinal profiles of Side Plates A and C and End Plates B and D, respectively. The longitudinal scans were made between the first and twelf th tabs because of the limitation of the carriage travel. Figure 11 shows the transverse profiles made at either end of the element.

The code used for each individual scan consists of two letters. The first letter indicates the plate being scanned. The second letter indicates the position of the scan on the plate. Hence, Scan BC was the scan on End Plate B, 3/4 in. from the plate center line toward Side Plate $C$. Scan AM was the scan along the longitudinal center line of Side Plate A. Upon completion of the profile scanning, it was necessary to remove the end section to allow plate-spacing measurements and gamma-ray-activity scans to be made.

\section{End-Section Removal}

The end sections were removed by cutting through the fuel-box assembly about $1 / 2$ in. from the weld which joined the box assembly to the end sections. A remotely operated power hacksaw was used for the operation. To avoid tearing the element side plates, a hand hacksaw blade having 32 teeth per in. was used. This blade was too light for the power machine and tended to bend. Consequently, the cuts were not perpendicular to the axis of the element. The angular cuts resulted in a piece of the end sections being left in the end of the fuel-box assembly (Figure 12). These pieces were easily removed, allowing the plate-spacing measurements to be taken.

$\underline{\text { Plate-Spacing Measurements }}$

The plate-spacing measurements were made with oval-shaped go-no-go gages. The major diameter of the gages was machined to a given nominal size with tolerances 


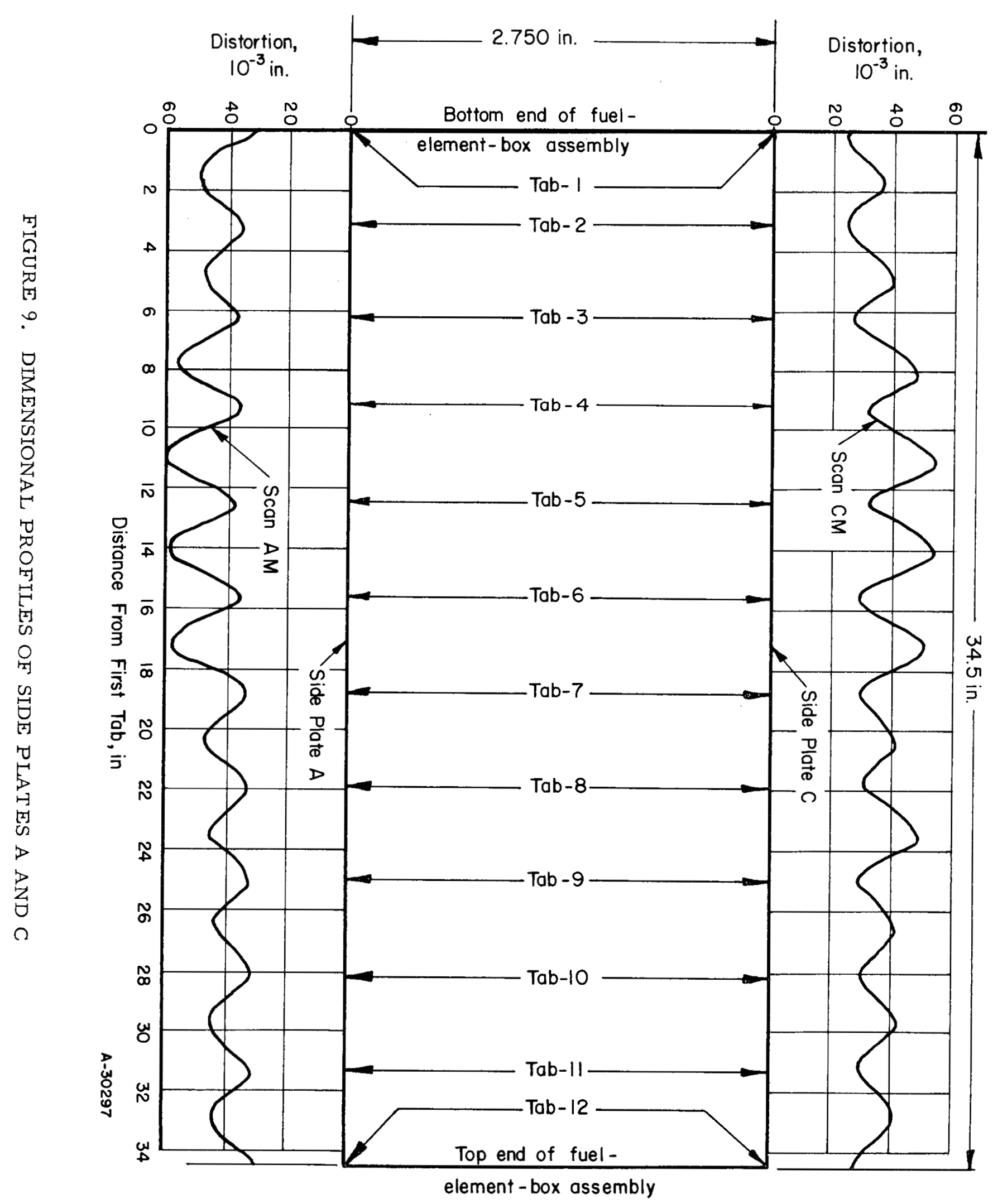




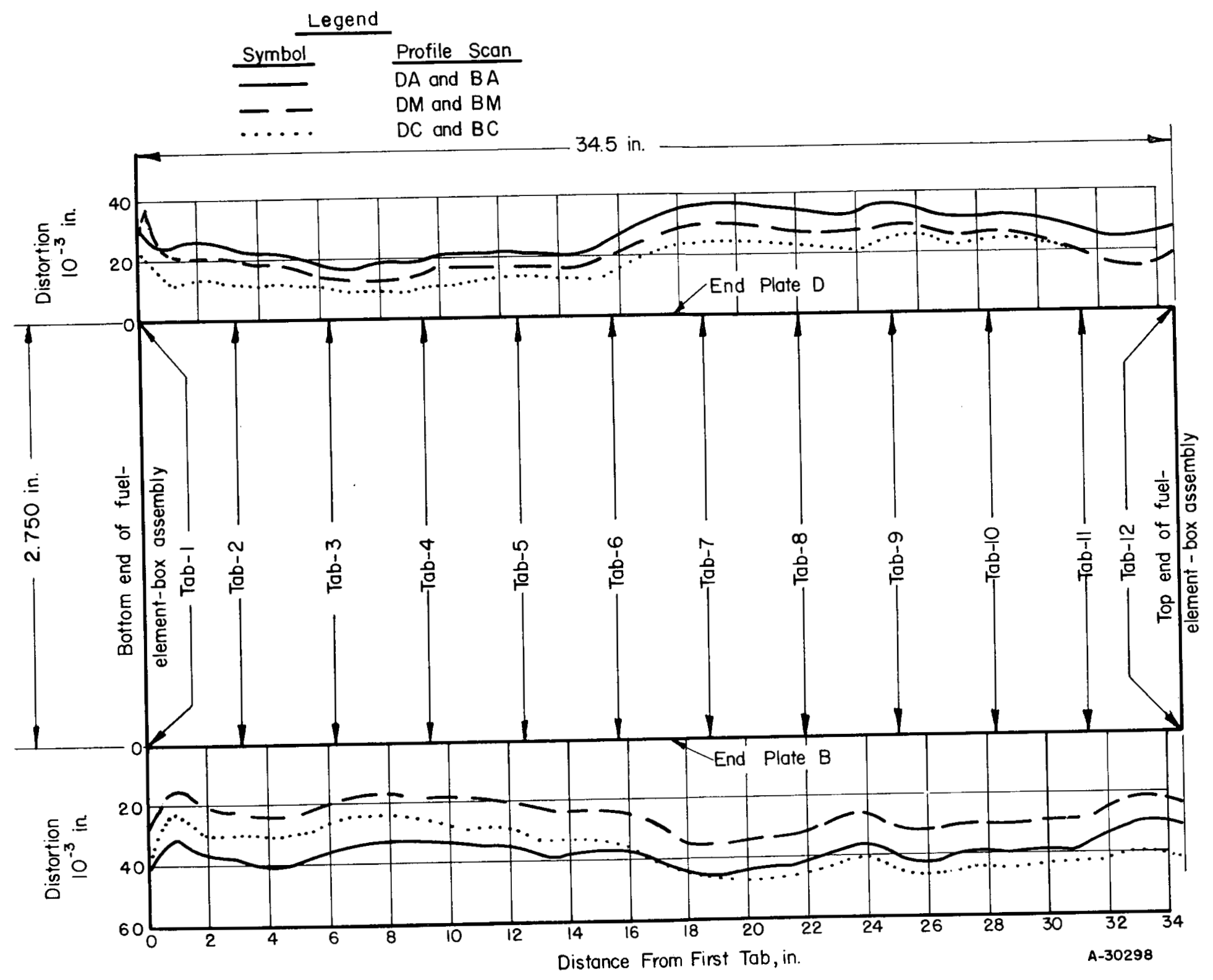

FIGURE 10. DIMENSIONAL PROFILES OF END PLATES B AND D 


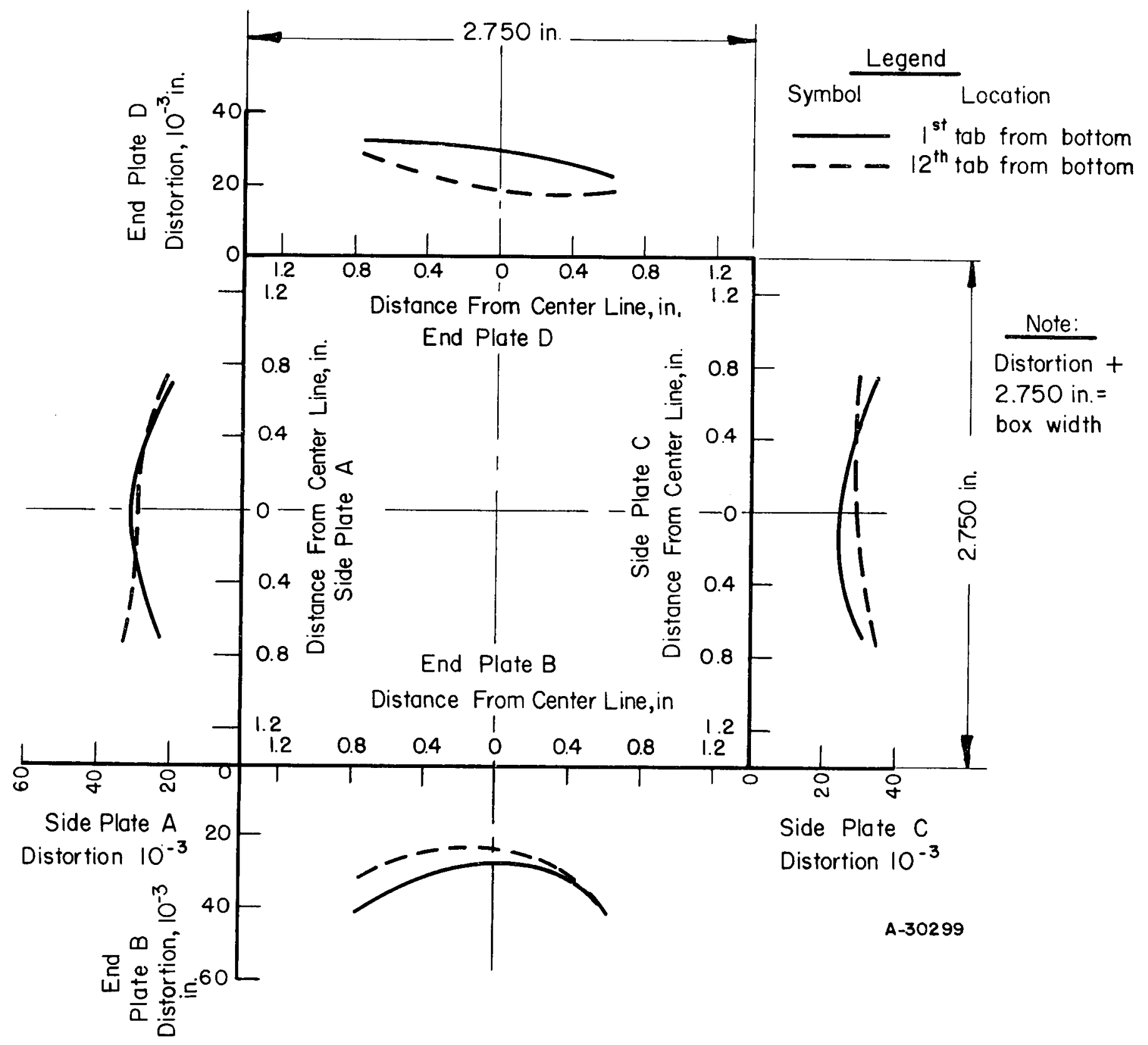

FIGURE 11. TRANSVERSE DIMENSIONAL-PROFILE SCANS 


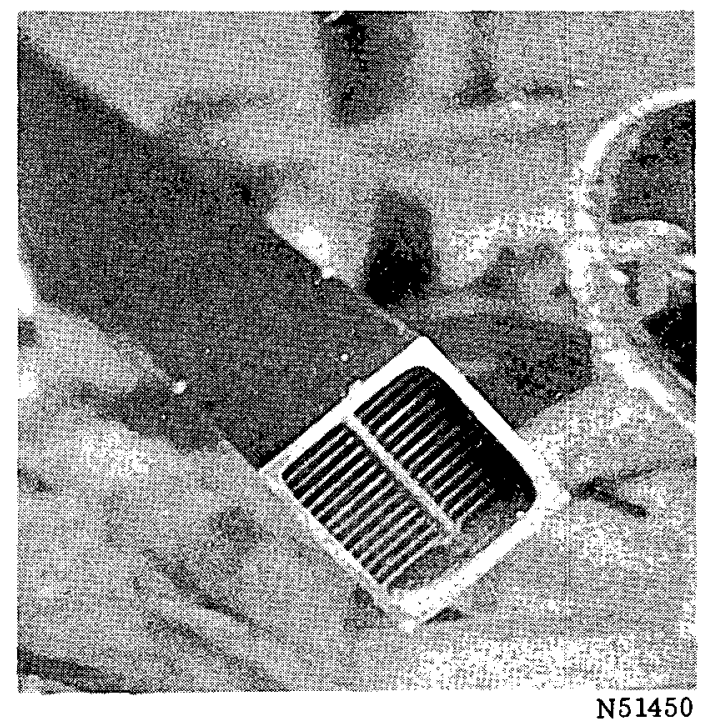

FIGURE 12. FUEL-ELEMENT BOX AFTER AN END SECTION WAS REMOVED

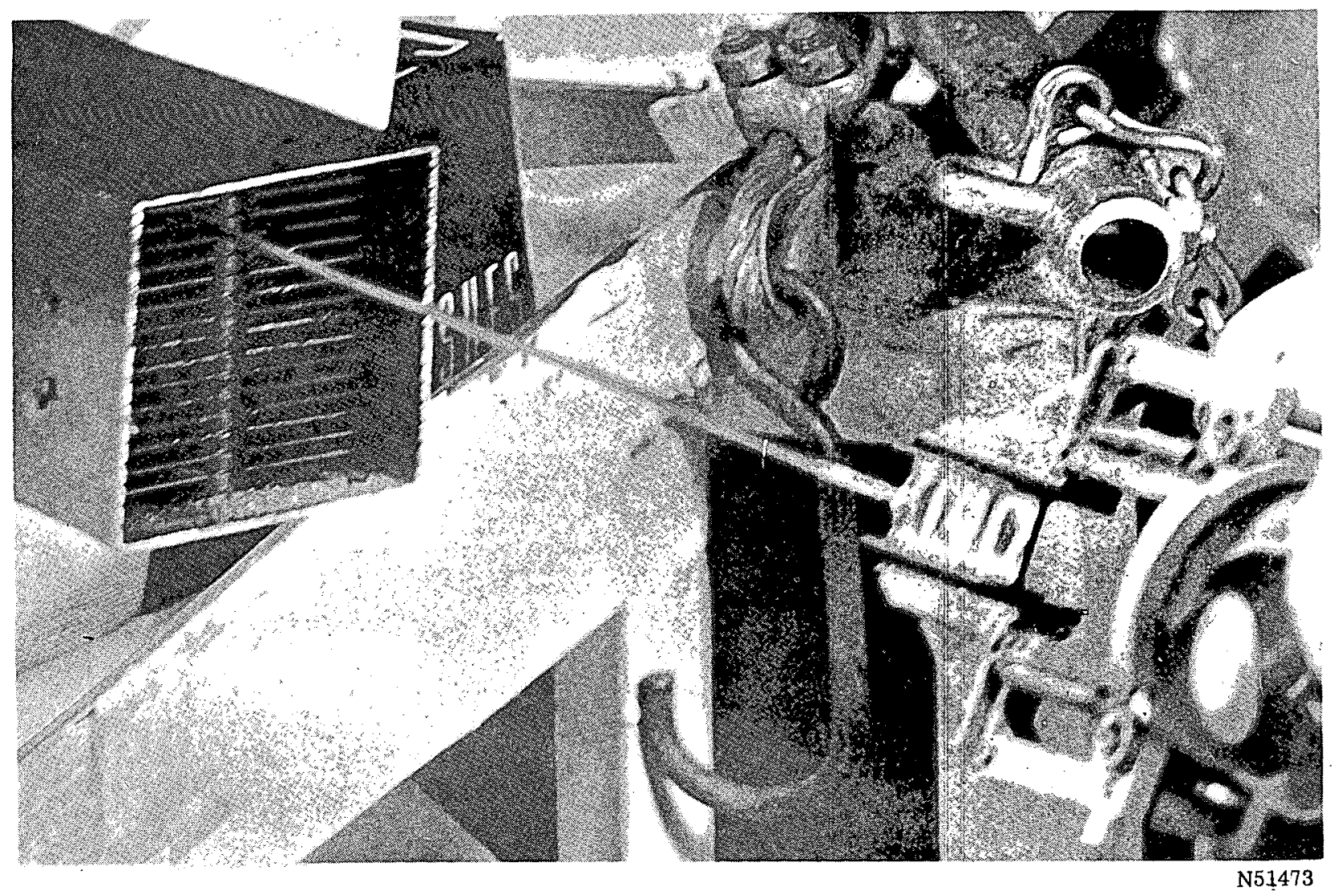

FIGURE 13. FUEL-ELEMENT BOX DURING CHANNEL-SPACING MEASUREMENTS 
of $\pm 0.0001 \mathrm{in.}$ When taking a measurement, the gage, mounted on a $0.100-\mathrm{in} .-$ diameter rod, was inserted between two plates with the major diameter of the gage parallel with the plates. Upon reaching the desired depth, the gage was turned $90 \mathrm{deg}$, if possible, to obtain a go or no-go reading. The gages used for the examination of the fuel-box assembly were in nominally 0.002-in. increments. Figure 13 shows the manner in which the measurements were made.

The results of the spacing measurements are tabulated in Tables 2 and 3 and the changes in plate spacing are tabulated in Tables 4 and 5.

Inspection of the spaces between the fuel plates indicated that they were free of obstructions. The plate surfaces appeared to be smooth and undistorted.

Measurements of the Gamma Radiation Emitted From the Fuel Element

The fuel-element assembly was scanned and the relative intensity of the gamma radiation was measured. These data can be interpreted to give the relative distribution of burnup over the length of the element and from this a picture can be obtained of the vertical distribution of neutron flux along the subassembly length.

For this measurement, the fuel element was positioned in an apparatus mounted inside the cell that could move the element either vertically or horizontally past a 0.125-in. hole through the cell wall. The radiation emitted through the hole was measured with a sodium iodide (T1) scintillation crystal. The pulses from the crystal were recorded with a pulse-height analyzer. A sketch of the apparatus is shown in Figure 14.

Two scans of the fuel-box assembly were made, one along each end plate. Figures 15 and 16 show the results of these scans. Only those gamma energies between 150 and $200 \mathrm{kev}$ were recorded. The scanning speed was slightly different for each scan. This did not affect the general shape of the curve, except for its width, since the response time of the scintillation detector was more than adequate even for the fastest scanning speed. The gamma scans completed the examination of the fuel-element box prior to its disassembly.

Examination of the Fuel Plates and Interior of the Fuel-Element Box

It was necessary to disassemble the fuel-element box in order to closely examine the fuel-element plates. The milling operation is shown in Figure 17. All of the tabs and the plug welds holding the centering pin in place were removed, and then the corner welds around one side plate were milled loose. After the plates were removed from the box assembly, they were identified and visually inspected for obvious defects. Three plates, including the two outside plates and one from the middle of the assembly, were selected for intensive examination. These plates were closely inspected with the stereomacroscope, gamma scanned, and selected areas were analyzed for burnup by radiochemical techniques. The gamma-scan and burnup-analysis data were used to prepare a burnup profile of the plates. In addition, the thickness of several plates was measured, a sample of the organic residue was collected, two metallographic analyses were performed, and the thickness of the organic residue was measured. Photographs were prepared of representative and unique areas. 
TABLE 2. POSTIRRADIATION FUEL-PLATE-SPACING MEASUREMENTS A.T $5 / 8$ IN. FROM SIDE PLATE A(a)

\begin{tabular}{|c|c|c|c|c|c|c|}
\hline \multirow[b]{3}{*}{ Space } & \multicolumn{6}{|c|}{ Measured Plate Spacing, in. } \\
\hline & \multicolumn{3}{|c|}{$\begin{array}{c}\text { At Indicated Distance From } \\
\text { Top End }\end{array}$} & \multicolumn{3}{|c|}{$\begin{array}{c}\text { At Indicated Distance From } \\
\text { Bottom End }\end{array}$} \\
\hline & 3 In. & 11 In. & $18 \mathrm{In}$. & $18 \mathrm{In}$ & $11 \mathrm{In}$. & $3 \mathrm{In}$. \\
\hline End Plate D & -- & -- & -- & -- & -- & -- \\
\hline 1 & 0.124 & 0.124 & 0.124 & 0.120 & (b) & $0.122(\mathrm{c})$ \\
\hline 2 & 0.134 & 0.132 & 0.134 & 0.136 & 0.138 & 0.136 \\
\hline 3 & 0.134 & 0.134 & 0.134 & 0.136 & 0.136 & $0.140(\mathrm{c})$ \\
\hline 4 & 0.134 & 0.134 & 0.134 & 0.136 & $0.140(c)$ & $0.142^{(c)}$ \\
\hline 5 & 0.134 & 0.134 & 0.132 & 0.136 & $0.140^{(c)}$ & $0.140^{(c)}$ \\
\hline 6 & 0.132 & 0.130 & 0.132 & $0.138^{(c)}$ & 0.136 & 0.138 \\
\hline 7 & 0.130 & 0.132 & 0.132 & 0.136 & 0.138 & 0.138 \\
\hline 8 & 0.134 & 0.132 & 0.134 & 0.136 & 0.138 & 0.138 \\
\hline 9 & 0.134 & 0.134 & 0.134 & 0.138 & 0.138 & $0.138^{(c)}$ \\
\hline 10 & 0.128 & 0.128 & 0.132 & 0.138 & 0.138 & 0.138 \\
\hline 11 & 0.130 & 0.130 & 0.132 & 0.136 & $0.140^{(\mathrm{c})}$ & $0.138^{(c)}$ \\
\hline 12 & 0.132 & 0.132 & 0.132 & 0.136 & $0.140(\mathrm{c})$ & $0.140(\mathrm{c})$ \\
\hline 13 & 0.128 & 0.132 & 0.134 & 0.136 & $0.138^{(c)}$ & 0.138 \\
\hline 14 & 0.134 & 0.130 & 0.130 & $0.138^{(c)}$ & $0.140^{(c)}$ & $0.140^{(\mathrm{c})}$ \\
\hline 15 & 0,130 & 0.134 & 0.132 & 0.136 & 0.136 & 0.138 \\
\hline 16 & 0.134 & 0.134 & 0.132 & 0.134 & 0.136 & 0.136 \\
\hline 17 & 0.122 & 0.122 & 0.120 & 0.118 & 0.118 & 0.120 \\
\hline End Plate B & -- & -- & - & -- & -- & -- \\
\hline
\end{tabular}

(a) The size of the largest go gage is given. The next larger gage (0.002 in. larger) would not "go".

(b) Smaller than 0.116 in., the size of the smallest available gage.

(c) Gage would "go" but as a snug fit. 
TABLE 3. POSTIRRADIATION FUEL-PLATE-SPACING MEASUREMENTS AT 5/8 IN. FROM SIDE PLATE C(a)

\begin{tabular}{|c|c|c|c|c|c|c|}
\hline \multirow[b]{3}{*}{ Space } & \multicolumn{6}{|c|}{ Measured Plate Spacing, in: } \\
\hline & \multicolumn{3}{|c|}{$\begin{array}{c}\text { At Indicated Distance From } \\
\text { Top End }\end{array}$} & \multicolumn{3}{|c|}{$\begin{array}{c}\text { At Indicated Distance From } \\
\text { Bottom End }\end{array}$} \\
\hline & 3 In. & $11 \mathrm{In}$. & $18 \mathrm{In}$. & 18 In. & $11 \mathrm{In}$. & $3 \mathrm{In}$. \\
\hline End Plate D & -- & -- & -- & -- & -- & -- \\
\hline 1 & 0.118 & 0.122 & 0.122 & 0.120 & (b) & 0.120 \\
\hline 2 & 0.138 & 0.132 & 0.136 & 0.130 & 0.134 & 0.130 \\
\hline 3 & $0.138^{(c)}$ & $0.138^{(c)}$ & $0.138^{(c)}$ & 0.136 & 0.132 & 0.134 \\
\hline 4 & 0.138 & 0.138 & 0.136 & 0.134 & 0.136 & 0.134 \\
\hline 5 & $0.138^{(c)}$ & $0.138(\mathrm{c})$ & $0.138^{(c)}$ & 0.130 & 0.134 & 0.134 \\
\hline 6 & 0.140 & 0.138 & 0.138 & 0.134 & 0.132 & 0.134 \\
\hline 7 & 0.132 & 0.136 & 0.132 & 0.136 & 0.138 & $0.138(\mathrm{c})$ \\
\hline 8 & 0.132 & 0.136 & 0.132 & $0.134(c)$ & 0.134 & 0.134 \\
\hline 9 & 0.140 & 0.140 & 0.140 & 0.132 & 0.132 & 0.134 \\
\hline 10 & 0,136 & $0.132(\mathrm{c})$ & $0.132^{(c)}$ & 0.130 & 0.132 & 0.130 \\
\hline 11 & $0.136^{(c)}$ & 0.136 & 0.136 & 0.132 & 0.132 & 0.132 \\
\hline 12 & 0.140 & 0.138 & $0.136(c)$ & 0.134 & 0.134 & 0.134 \\
\hline 13 & 0.132 & $0.132^{(c)}$ & 0.130 & 0.134 & 0.130 & 0.134 \\
\hline 14 & 0.138 & 0.136 & 0.132 & 0.132 & $0.132^{(c)}$ & 0.130 \\
\hline 15 & 0.136 & 0.138 & 0.140 & 0.132 & $0.132(\mathrm{c})$ & 0.134 \\
\hline 16 & 0.136 & 0.136 & $0.132^{(\mathrm{c})}$ & 0.132 & 0.134 & 0.130 \\
\hline 17 & 0.124 & 0.122 & 0.122 & 0.118 & (b) & $0.122^{(c)}$ \\
\hline End Plate B & -- & -- & -- & -- & -- & -- \\
\hline
\end{tabular}

(a) The size of the largest go gage is given. The next larger gage $(0.002$ in. larger) would not "go".

(b) Smaller than 0.116 in.. the size of the smallest available gage.

(c) Gage would "go" but was a snug fit. 
TABLE 4. CHANGE IN FUEL-PLATE SPACING AT 5/8 IN. FROM SIDE PLATE A

\begin{tabular}{|c|c|c|c|c|c|c|}
\hline \multirow[b]{3}{*}{ Space } & \multicolumn{6}{|c|}{ Measured Change in Plate Spacing, mils } \\
\hline & \multicolumn{3}{|c|}{$\begin{array}{l}\text { At Indicated Distance } \\
\text { From Top End }\end{array}$} & \multicolumn{3}{|c|}{$\begin{array}{l}\text { At Indicated Distance } \\
\text { From Botiom End }\end{array}$} \\
\hline & $3 \operatorname{In}$. & $11 \mathrm{In}$. & $18 \operatorname{In}$. & $\overline{18 \mathrm{In} .}$ & $11 \mathrm{In}$. & $3 \mathrm{In}$. \\
\hline End Plate D & - & -- & -- & -- & -- & -- \\
\hline 1 & -6 & -8 & 4 & 0 & -- & 2 \\
\hline 2 & 1 & -2 & -6 & 1 & 7 & 0 \\
\hline 3 & -4 & -2 & -2 & -3 & 0 & 4 \\
\hline 4 & 0 & -5 & -7 & -3 & 2 & 4 \\
\hline 5 & 1 & 1 & 1 & 2 & 5 & 5 \\
\hline 6 & 0 & -4 & 2 & -1 & -5 & -1 \\
\hline 7 & -8 & -7 & -9 & 1 & 8 & -1 \\
\hline 8 & -2 & 0 & 0 & 2 & 6 & 8 \\
\hline 9 & 3 & 0 & 3 & -1 & 0 & 0 \\
\hline 10 & -10 & -10 & -7 & 1 & 2 & 4 \\
\hline 11 & -6 & -4 & -2 & 1 & 3 & 2 \\
\hline 12 & -5 & -5 & -3 & 1 & 5 & 3 \\
\hline 13 & -6 & -3 & -8 & -3 & 4 & 8 \\
\hline 14 & -3 & -11 & -11 & 3 & 0 & 2 \\
\hline 15 & -6 & -4 & -6 & -5 & 0 & 1 \\
\hline 16 & -6 & -5 & -9 & 1 & 1 & 5 \\
\hline 17 & 2 & 2 & 0 & -1 & -2 & 0 \\
\hline End Plate B & - & -- & -- & -- & -- & - \\
\hline
\end{tabular}


TABLE 5. CHANGE IN FUEL-PLATE SPACING AT

5/8 IN. FROM SIDE PLATE C

\begin{tabular}{|c|c|c|c|c|c|c|}
\hline \multirow[b]{3}{*}{ Space } & \multicolumn{6}{|c|}{ Measured Change in Plate Spacing, mils } \\
\hline & \multicolumn{3}{|c|}{$\begin{array}{c}\text { At Indicated Distance From } \\
\text { Top End }\end{array}$} & \multicolumn{3}{|c|}{$\begin{array}{c}\text { At Indicated Distance From } \\
\text { Bottom End }\end{array}$} \\
\hline & 3 In. & 11 In. & $18 \mathrm{In}$. & $18 \mathrm{In}$. & $11 \mathrm{In}$ & 3 In. \\
\hline End Plate D & -- & -- & -- & -- & -- & -- \\
\hline 1 & -13 & -12 & -5 & -6 & - & 1 \\
\hline 2 & 7 & 1 & -4 & -4 & 2 & -6 \\
\hline 3 & 2 & 2 & 2 & -2 & -4 & 0 \\
\hline 4 & 4 & -1 & -3 & -5 & 0 & -2 \\
\hline 5 & 4 & 4 & 8 & -6 & -1 & 0 \\
\hline 6 & 1 & 0 & -1 & -5 & -9 & -3 \\
\hline 7 & -3 & 3 & -3 & 2 & 6 & 2 \\
\hline 8 & 1 & 2 & -1 & 0 & 1 & 2 \\
\hline 9 & 4 & 3 & 1 & -5 & -4 & -1 \\
\hline 10 & 0 & -3 & -3 & -4 & -4 & -7 \\
\hline 11 & -1 & 1 & 1 & -2 & -6 & -6 \\
\hline 12 & 3 & 0 & 2 & -3 & -2 & -1 \\
\hline 13 & -2 & -3 & -10 & -5 & -5 & 4 \\
\hline 14 & 4 & 0 & -4 & -2 & -7 & -1 \\
\hline 15 & 1 & 2 & 0 & -8 & -7 & -3 \\
\hline 16 & -3 & -3 & -11 & -3 & -9 & -13 \\
\hline 17 & 4 & 3 & 3 & -1 & -- & -2 \\
\hline End Plate B & -- & -- & - & -- & -- & -- \\
\hline
\end{tabular}




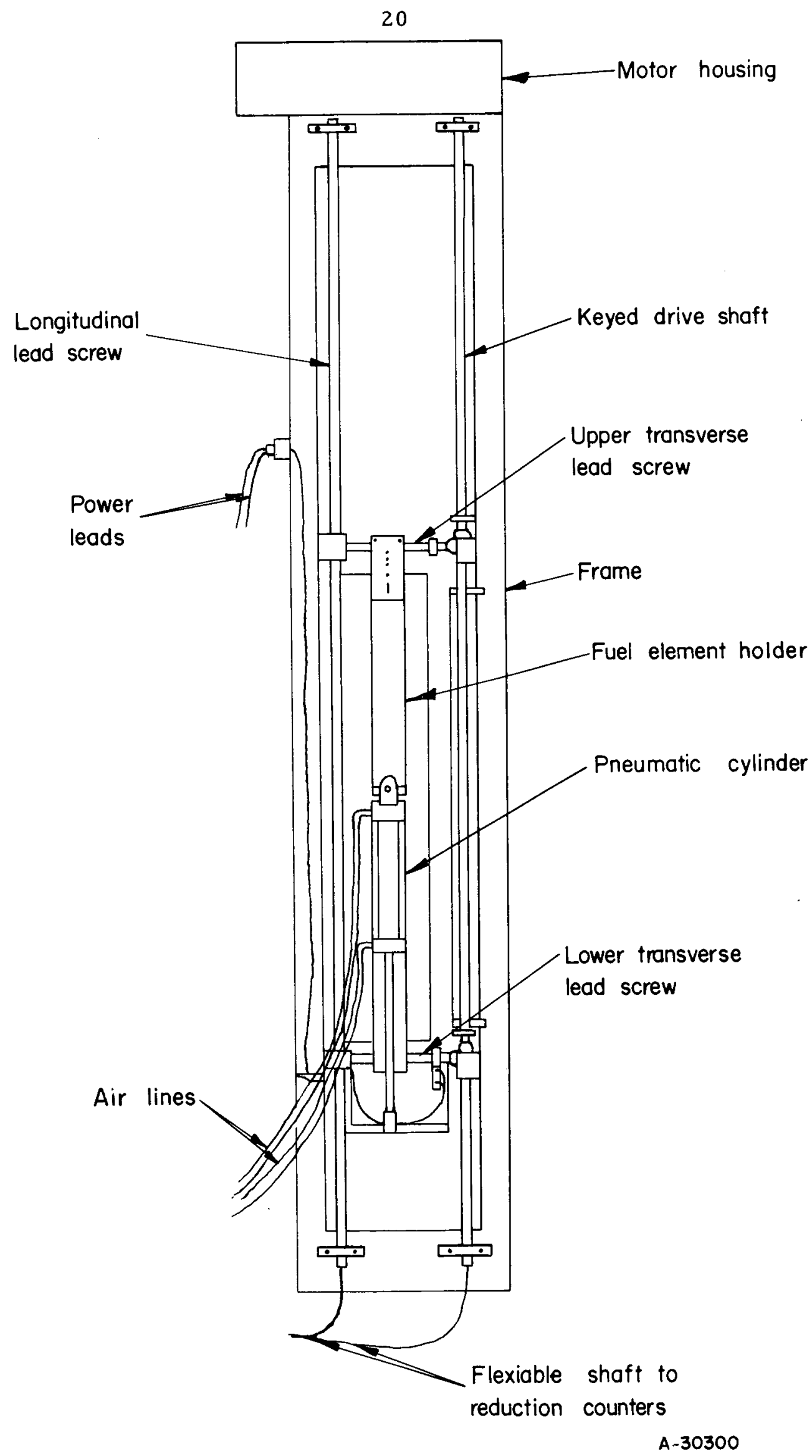

FIGURE 14. A SKETCH OF THE GAMMA-RAY SCANNER APPARATUS 


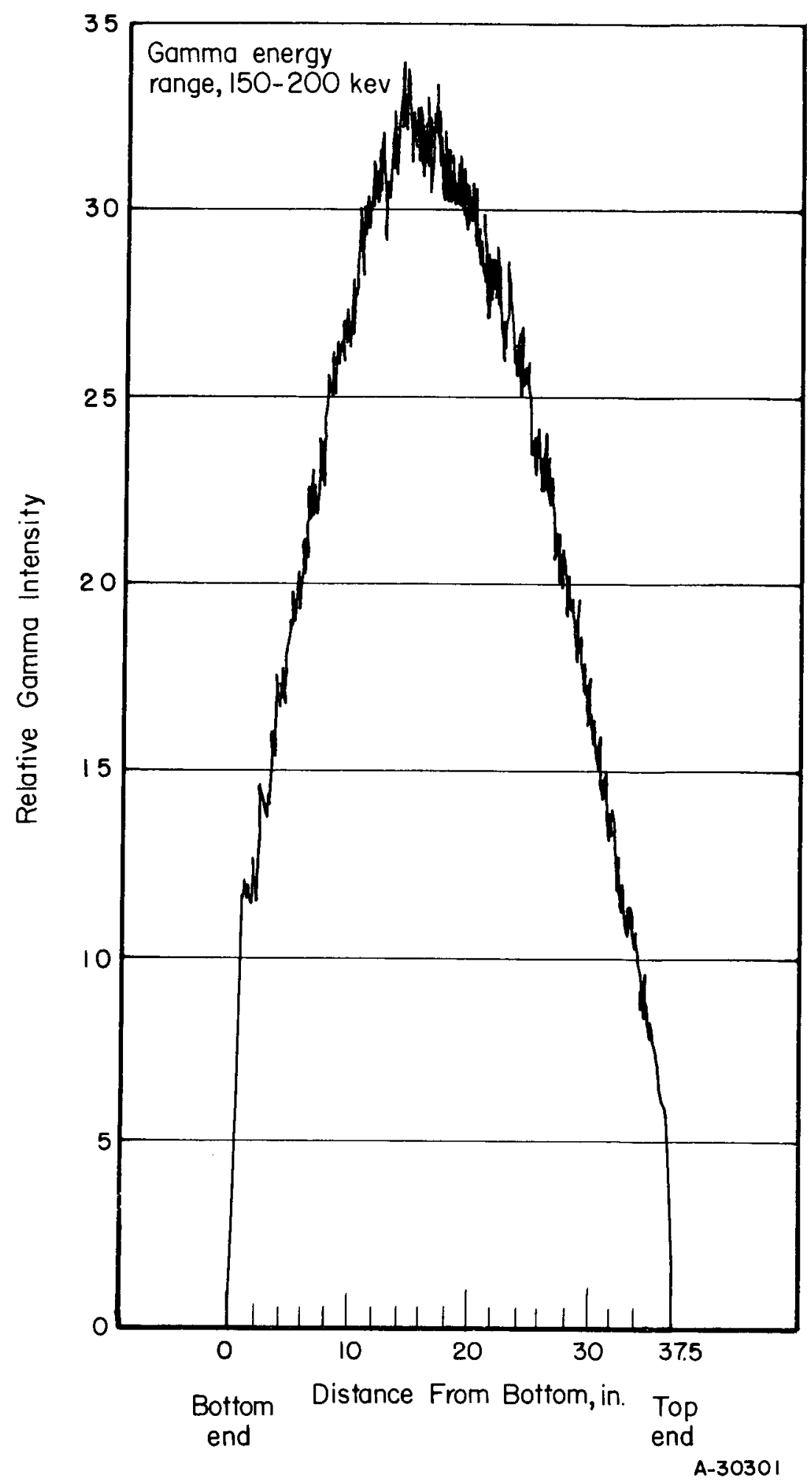

FIGURE 15. GAMMA-RAY ACTIVITY SCAN A AT CENTER LINE OF FUELELEMENT -BOX ASSEMBLY END PLATE B 
22

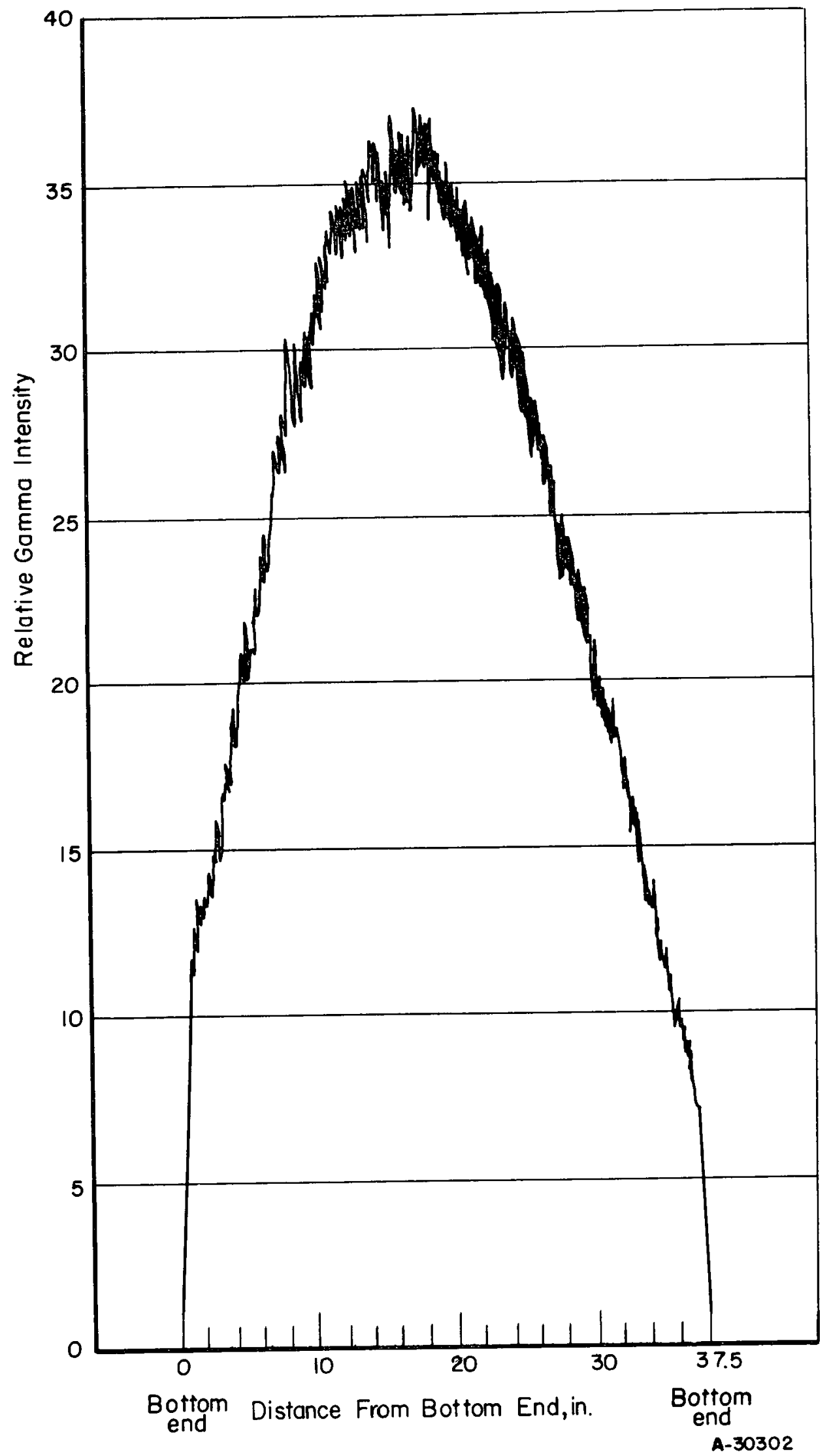

FIGURE 16. GAMMA -RAY ACTIVITY SCAN B AT CENTER LINE OF FUELELEMENT -BOX ASSEMBLY END PLATE D 


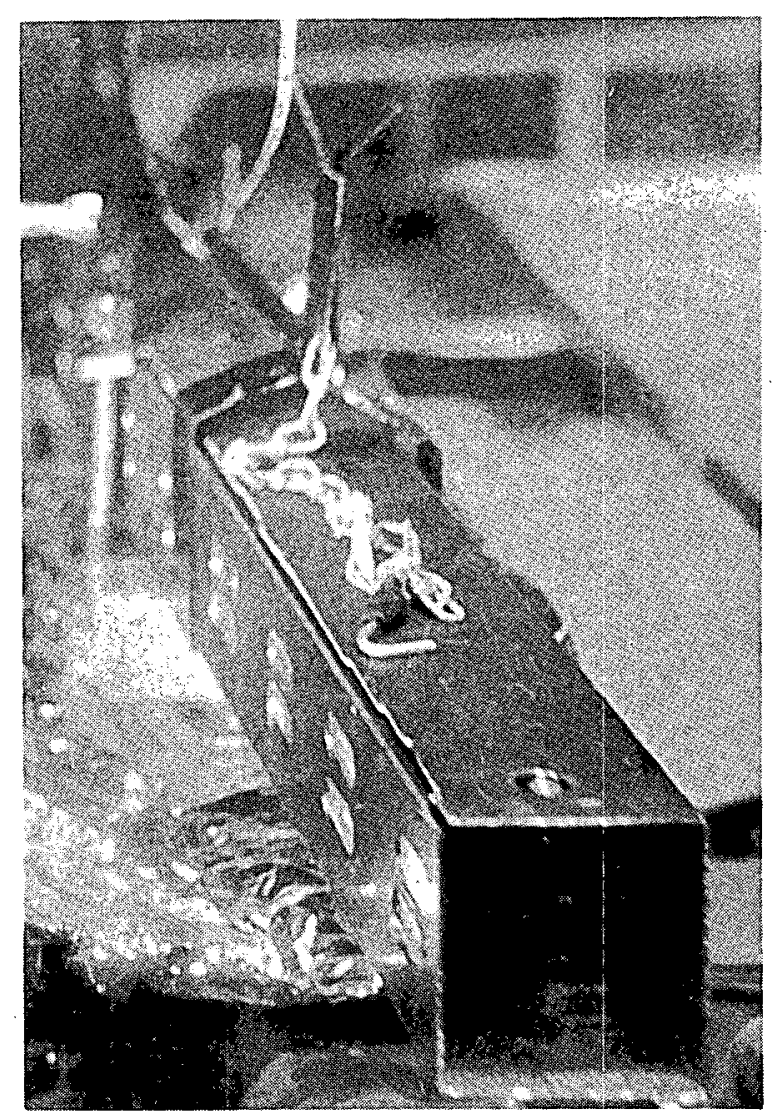

FIGURE 17. FUEL-ELEMENT BOX DURING MILLING OPERATION REQUIRED FOR OPENING

The tabs and the plug weld on the spacer have been cut away.

\section{Inspection of the Fuel Plates}

All of the plates were given a visual examination to determine their general condition. Each plate was covered with a hard black layer of organic residue. To the eye, the surface appeared smooth. There were no obvious signs of distortion, blisters, cracking, or other defects in the fuel plate. Three plates, 104-1, 103-2, and 104-2, were selected for intensive examination. Plates 104-1 and 104-2 were the outer plates in the element assembly, while 103-2 was in the center of the assembly. The outer plates experienced the highest average burnup, and the middle plate the lowest, thus giving a fairly representative sampling.

The surfaces of the three selected plates were examined at magnifications to $32 \mathrm{X}$ with the stereomacroscope. The surfaces of Plates 104-1, 103-2 and 104-2 were coated with the same tightly adhering, brittle, carbonaceous organic residue as the plates of the fuel-box shell. Small blisterlike blemishes had also formed in the residue layer on the fuel plates, as shown in Figures 18 and 19. Figure 18 also shows the typical appearance of a scratch in the organic residue. Figures 20 and 21 illustrate typical regions near the edges of the fuel plates. The blisters in the organic residue occur only over the fueled area of the plate. The depth to which the fuel plate fitted into the 


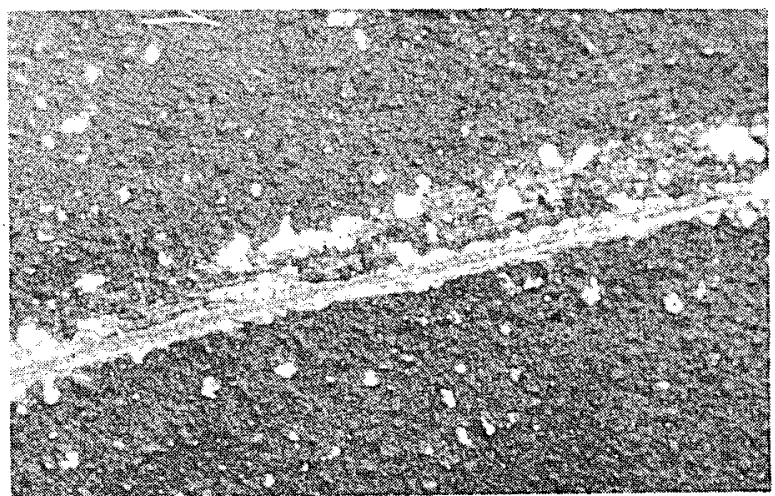

$21 \mathrm{X}$

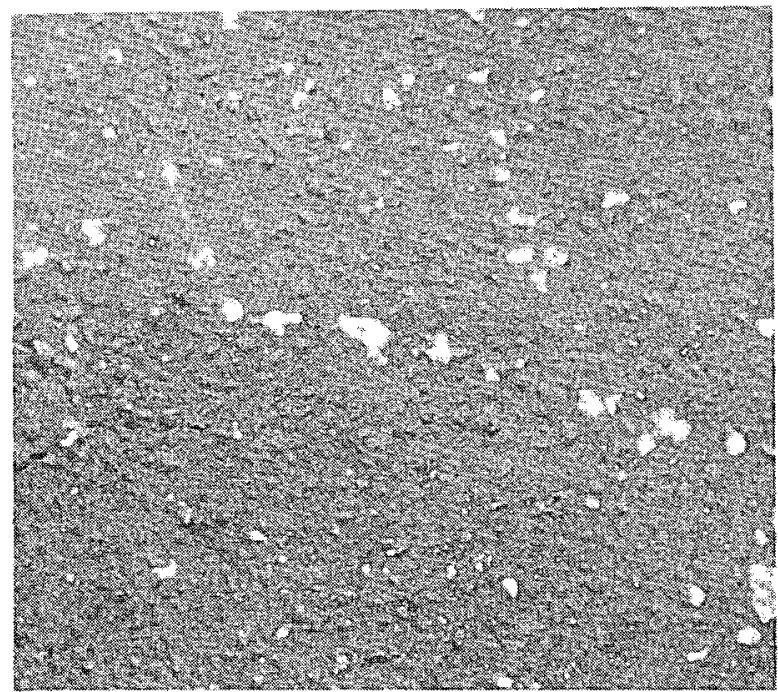

$21 X$

HC1816

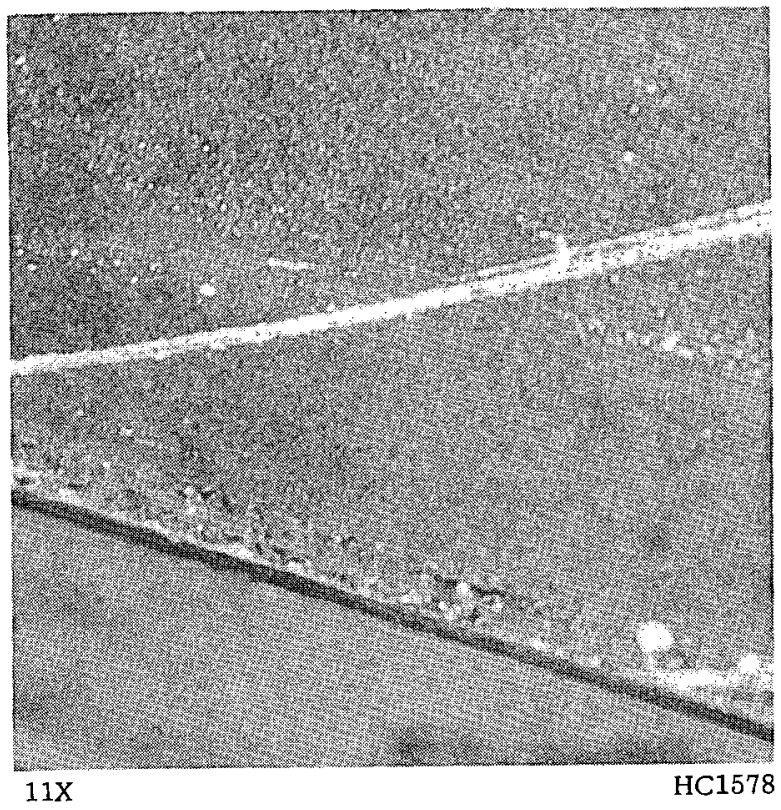

FIGURE 18. SCRATCH IN THE ORGANIC RESIDUE ON PLATE 104-1

Note the rough surface of the residue apparently caused by blisters. Residue appears to be more adherent than that on fuel-element box (Figure 5).
FIGURE 19. ANOTHER VIEW OF THE SURFA CE OF PLATE 104-1

Note blisters in the residue. Some have been scraped off, leaving bare metal.
FIGURE 20. AN AREA ADJACENT TO THE EDGE OF PLATE 104-2

Note that the blisters in the organic residue cover only the fueled area. 
side plate of the fuel-element box is also indicated by the relative cleanliness of the edge area.

Of the three fuel plates examined closely, the only observed evidence of a defect in the plate cladding was in a localized area approximately 10 in. from the bottom end of Plate 104-1. The pitted area is shown in Figures 22 and 23. The pits shown in Figure 23 are representative of the largest pits observed.

\section{Inspection of the Fuel-Element-Box Interior}

A visual examination was also performed on the interior surface of Side Plate A from the fuel-element box. Figure 24 shows the grooves in the side plate. Figures 25 and 26 show details of interesting regions of the center and lower grooves, respectively, on the photograph shown in Figure 24。

\section{Fuel-Plate-Temperature Measurements}

The temperatures of the fuel plates were measured periodically with Tempilstiks during the examination. The temperatures of the fuel plates were found to be near those measured on the surfaces of the fuel-element box. The temperature of the center third of each fuel plate was generally found to be greater than $150 \mathrm{~F}$ but less than $200 \mathrm{~F}$. The temperature of the remainder of the plates was generally greater than $113 \mathrm{~F}$ but less than $150 \mathrm{~F}$. These temperatures were measured approximately 6 weeks after unloading the element and are described in Appendix B.

During the course of the examination, it became necessary to store the fuel plates in a tight bundle in air inside a lead shipping cask. After 2 weeks of such storage, the plates were removed and temperature measurements were made. The bundle of plates was quickly removed from the cask, placed on a table, and split into approximately equal portions. Only $15 \mathrm{sec}$ elapsed between the time the bundle was opened and a temperature measurement was made with Tempilstiks. The maximum plate temperature was found to be less than $238 \mathrm{~F}$.

Gamma-Activity Scans of Fuel Plates

The relative intensity of gamma radiation emitted from Plates 104-1, 103-2, and 104-2.was measured by scanning. The equipment used was the same as that employed for the gamma scans of the fuel-element-box assembly. Each fuel plate was scanned along the longitudinal center line and at a minimum of three locations in the transverse direction. Figure 27 indicates the locations on each fuel plate at which the scans were made.

The gamma-ray-activity scans of the three selected fuel plates are shown in Figures 28 through 40, inclusive. Only gamma-ray energies between 150 and $200 \mathrm{kev}$ were measured. The length of the plates was considered as $37.5 \mathrm{in}$. rather than the nominal over-all length of $38.4 \mathrm{in}$. because the longitudinal scans passed through the slots for the spacer pins in either end of the fuel plates. 

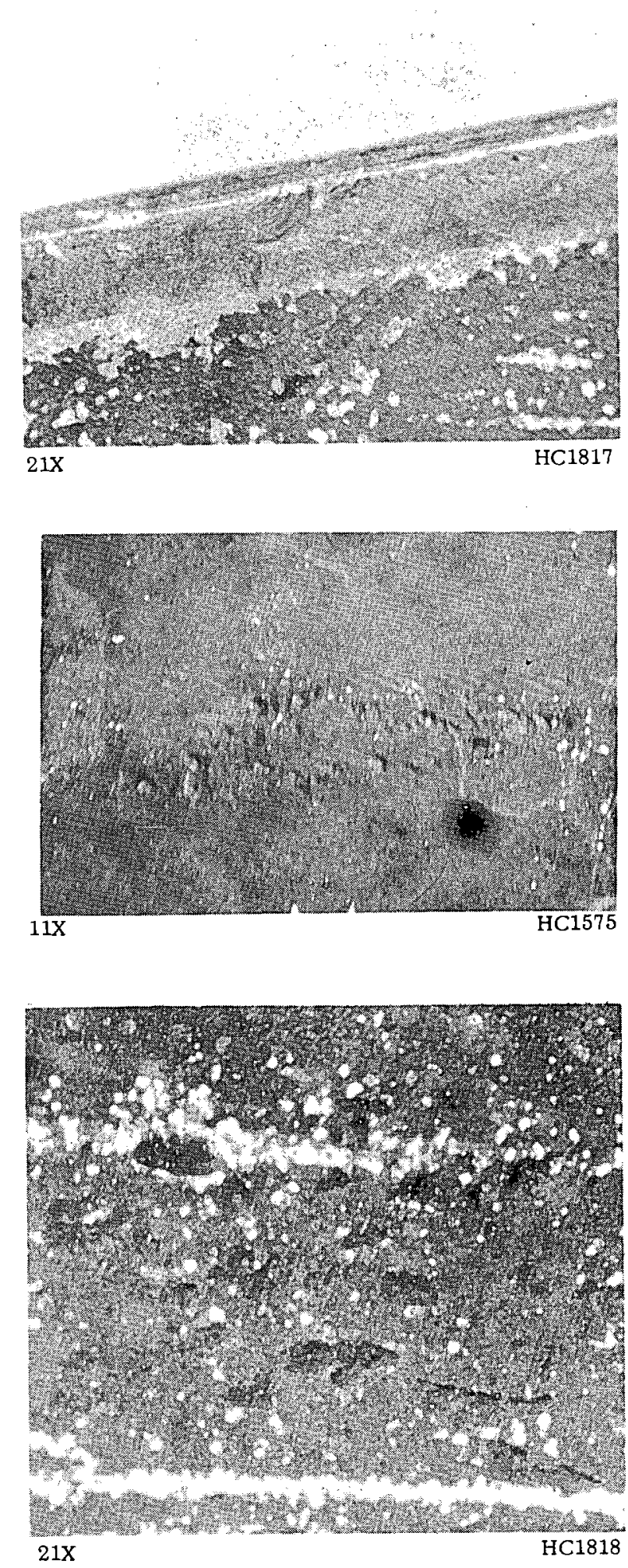

FIGURE 21. A DETAILED VIEW OF AN AREA NEAR THE EDGE OF PLATE 104-1

Note that the edge area is relatively free of tar. This edge fits the grooves in the side plates of the fuel-element box.
FIGURE 22, PITS OBSERVED IN THE SURFACE OF PLATE 104-1
FIGURE 23. A MAGNIFIED VIEW OF THE PITS IN PLATE 104-1 

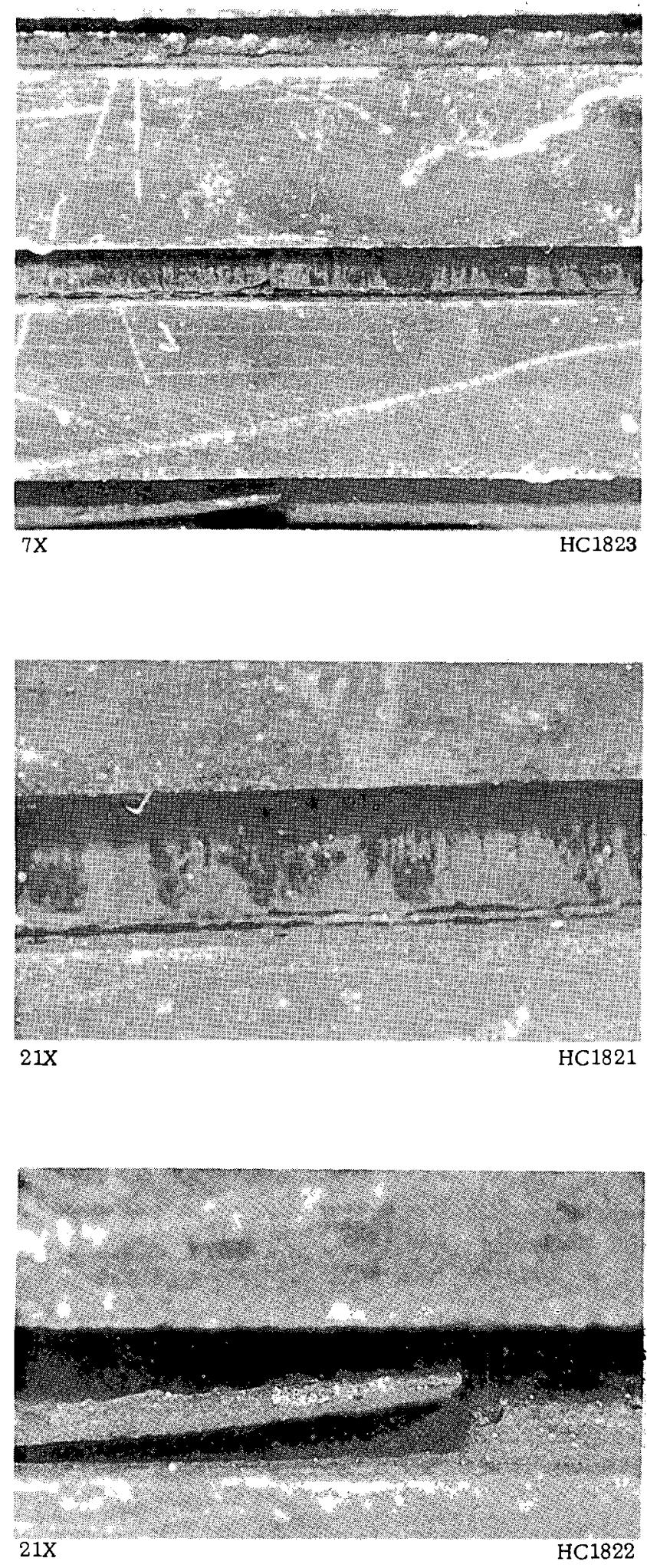

FIGURE 24. THE INTERIOR GROOVED SURFACE OF FUEL-ELEMENT-BOX SIDE PLATE A

Note the organic residue adhering to the groove sides The right end of the center groove and the center section of the bottom groove are shown at higher magnifications in Figures 25 and 26.

FIGURE 25. A MORE DETAILED VIEW OF THE CENTER GROOVE IN FIGURE 24

FIGURE 26. A MORE DETAILED VIEW OF THE BOTTOM GROOVE IN FIGURE 24

Part of the organic residue has pulled away from the edge of the groove. 

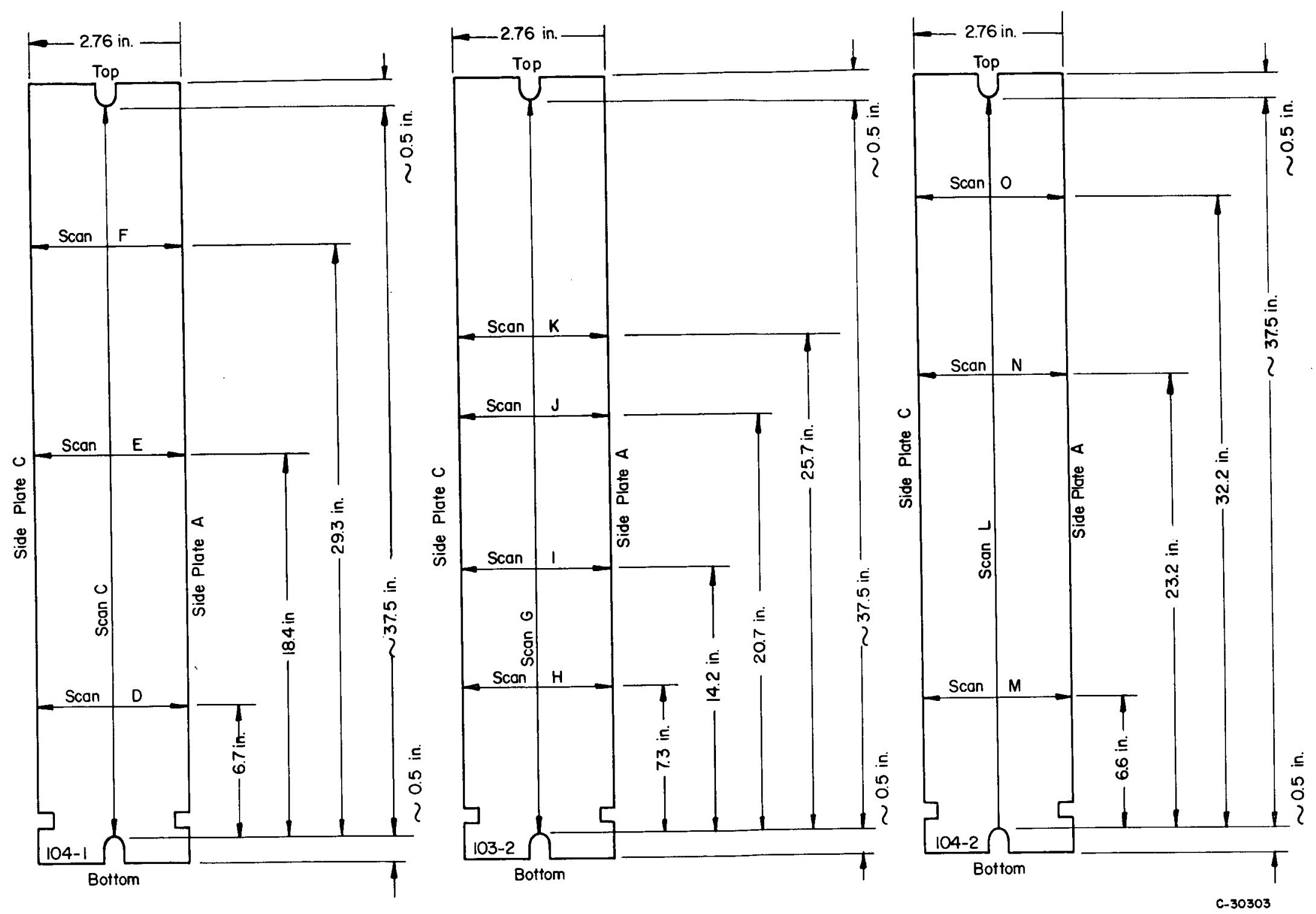

FIGURE 27. LOCATION OF GAMMA-RAY-ACTIVITY SCANS OF PLATES 104-1, 103-2, AND 104-2 


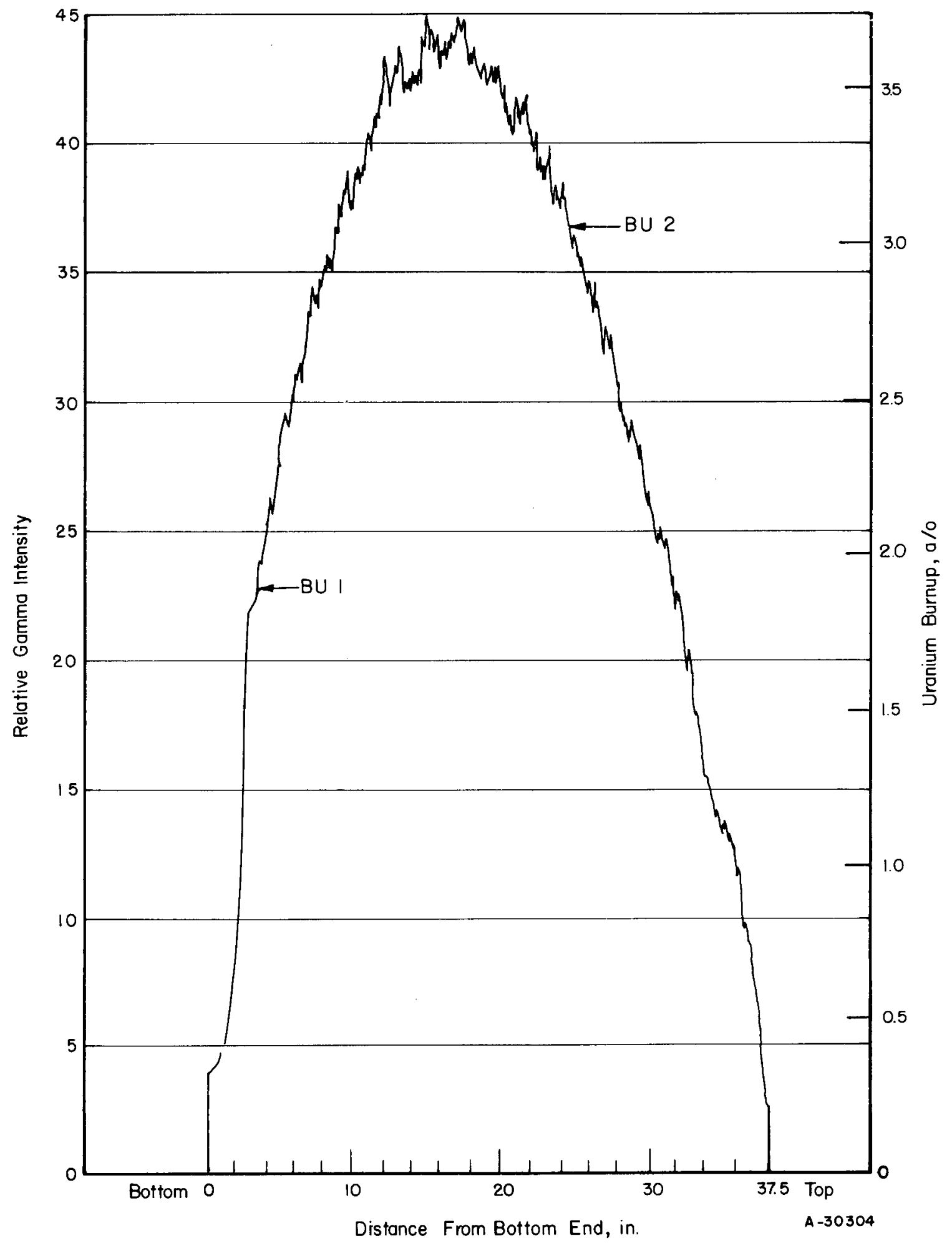

FIGURE 28. LONGITUDINAL GAMMA-RAY-ACTIVITY SCAN C AT CENTER LINE OF PLATE 104-1 


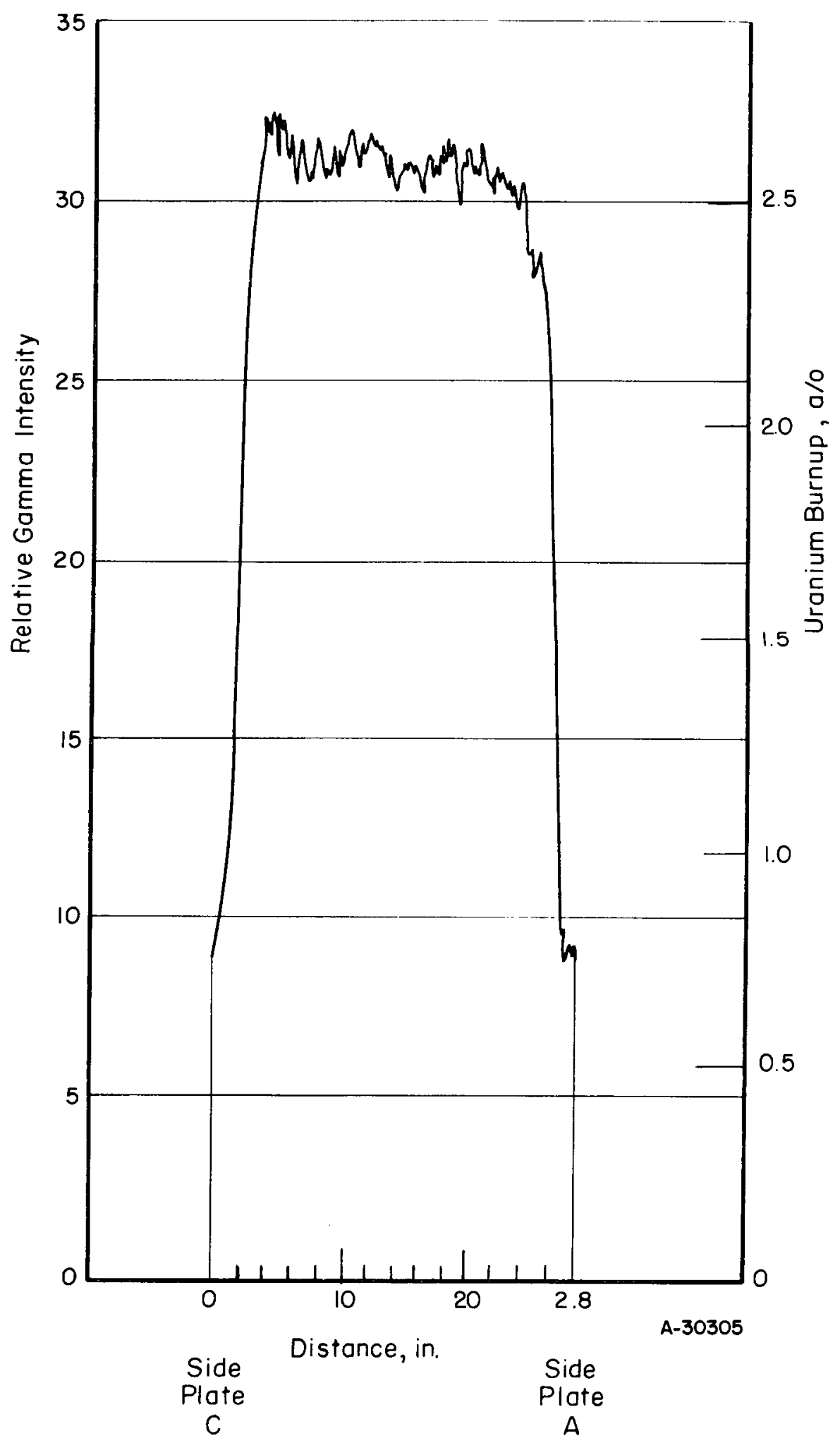

FIGURE 29. TRANSVERSE GAMMA-RAY-ACTIVITY SCAN D OF PLATE 104-1 


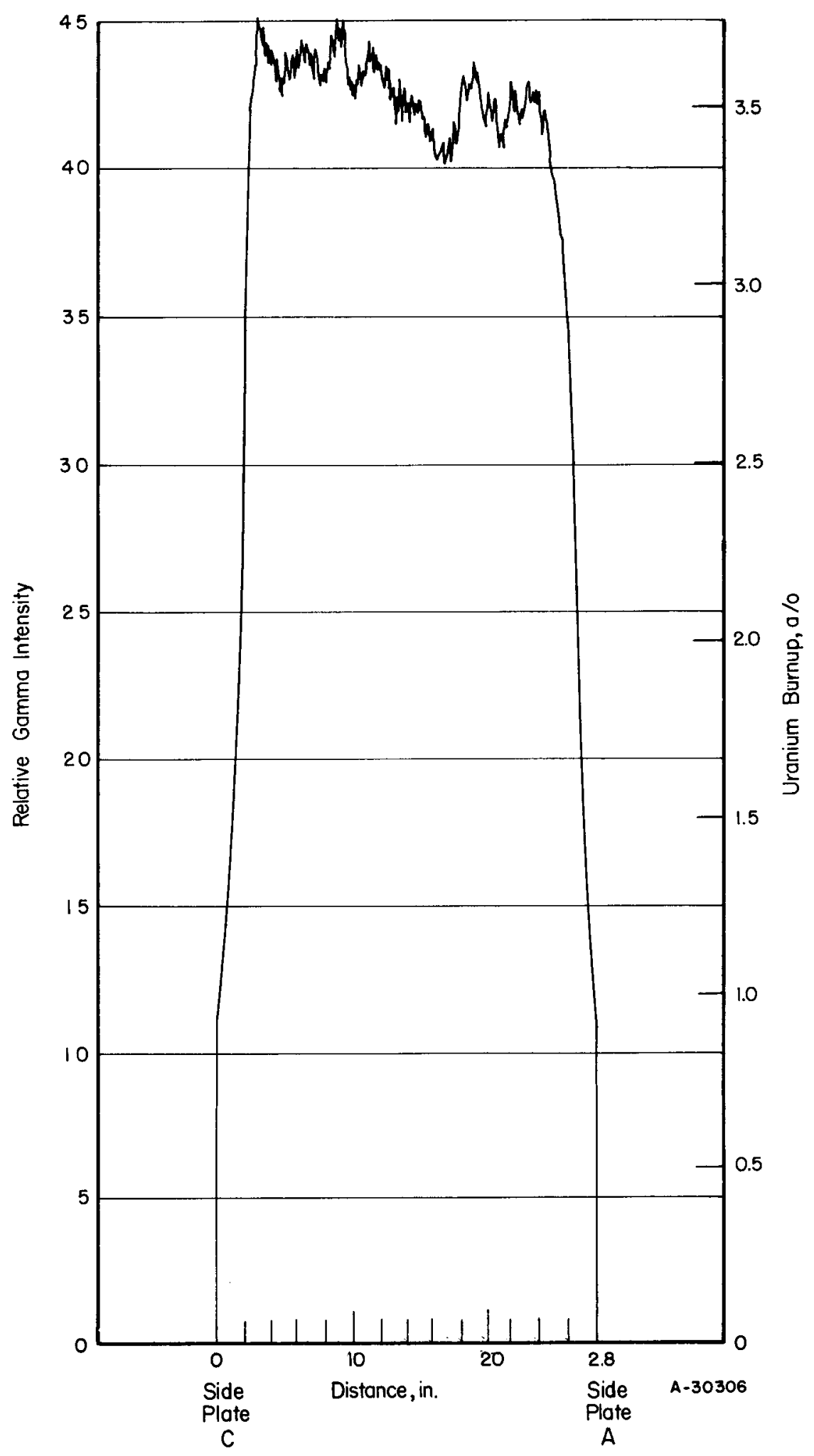

FIGURE 30. TRANSVERSE GAMMA-RAY-ACTIVITY SCAN E OF PLATE 104-1 


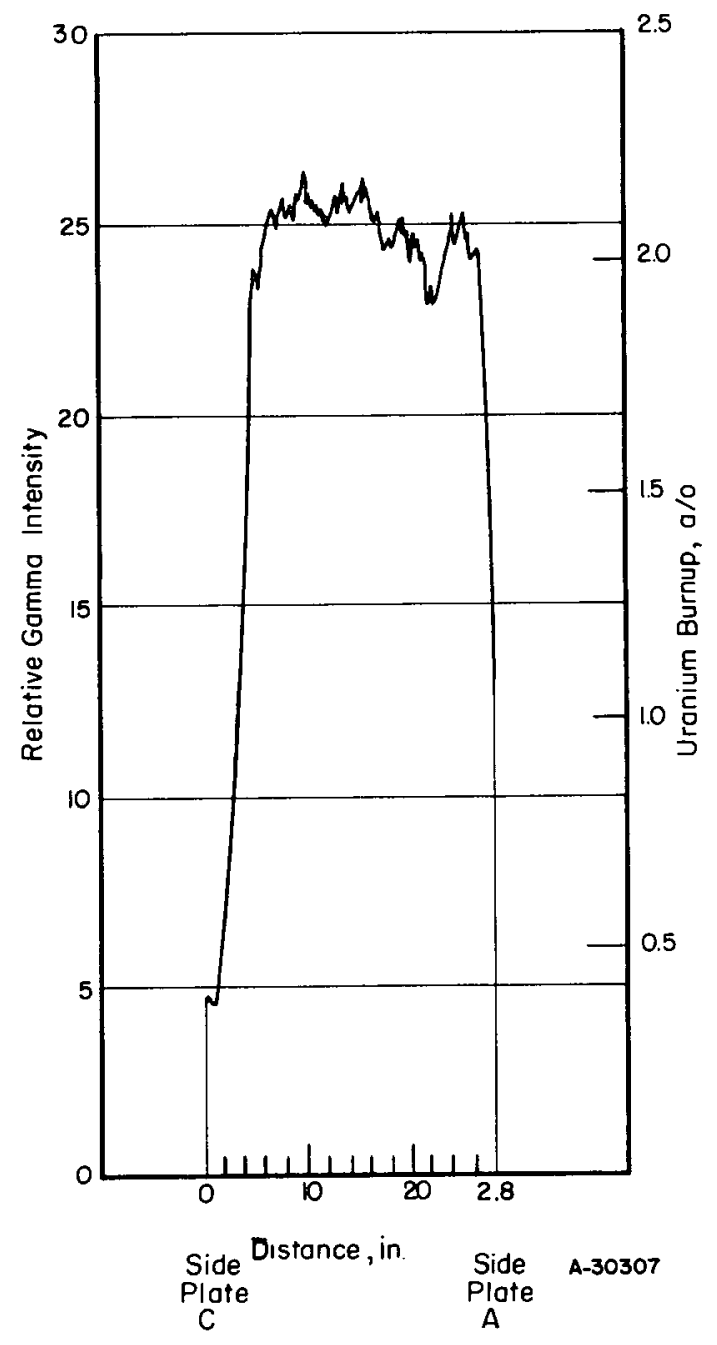

FIGURE 31. TRANSVERSE GAMMA-RAY-ACTIVIT Y SCAN F OF PLATE 104-1 


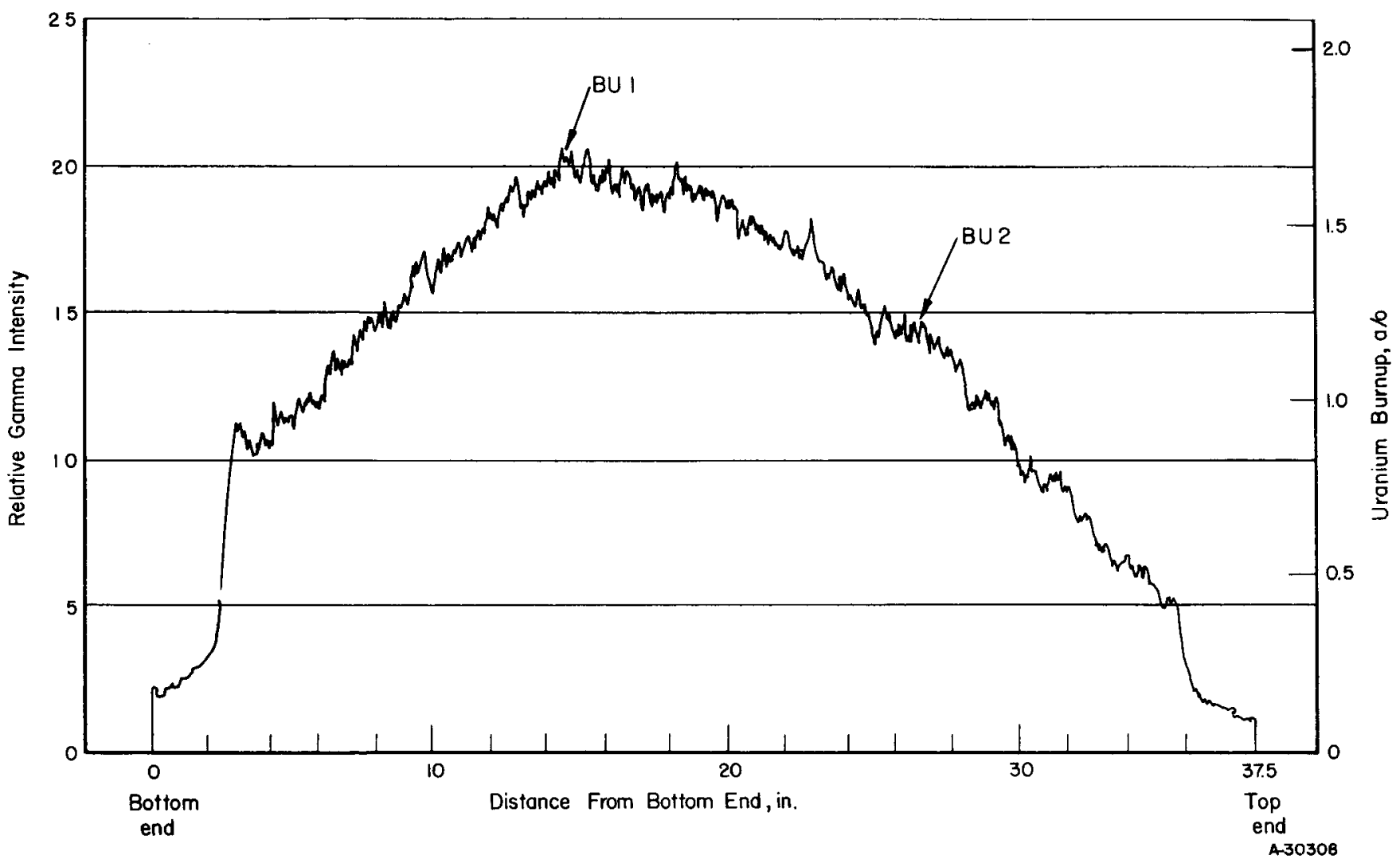

FIGURE 32. LONGIT UDINAL GAMMA-RAY-ACTIVITY SCAN G AT CENTER LINE OF PLATE 103-2 


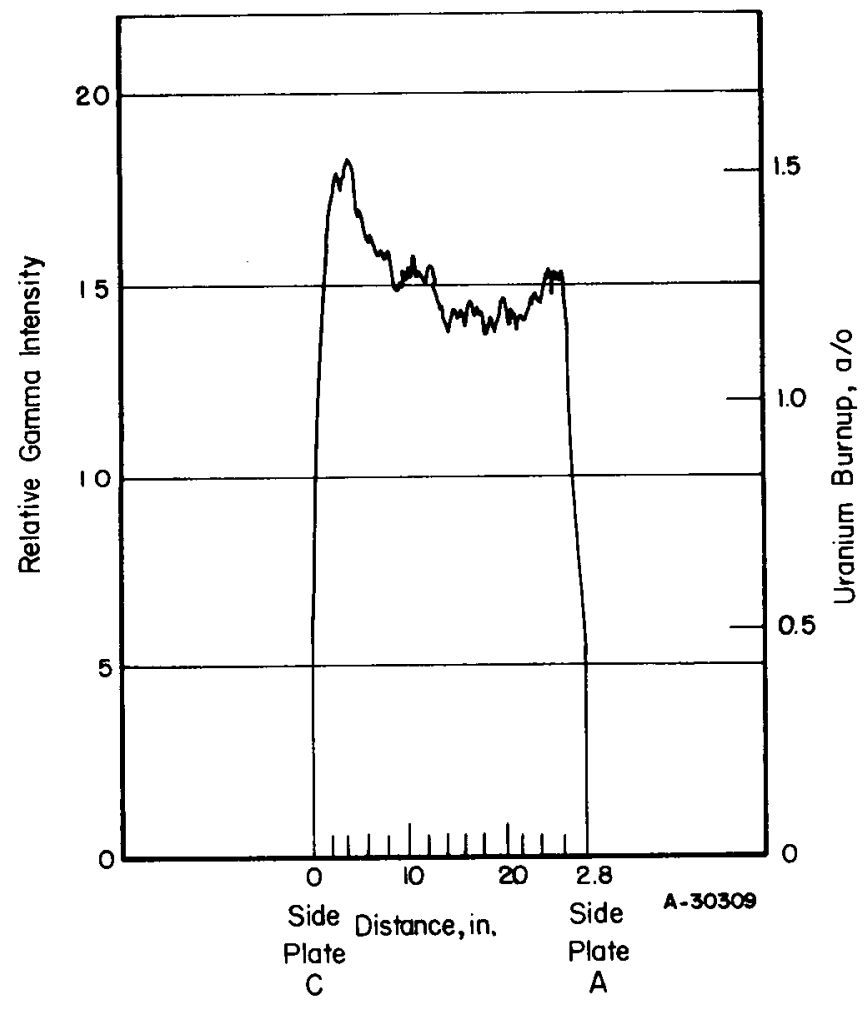

FIGURE 33. TRANSVERSE GAMMA-RAY-ACTIVIT Y SCAN H OF PLATE 103-2 


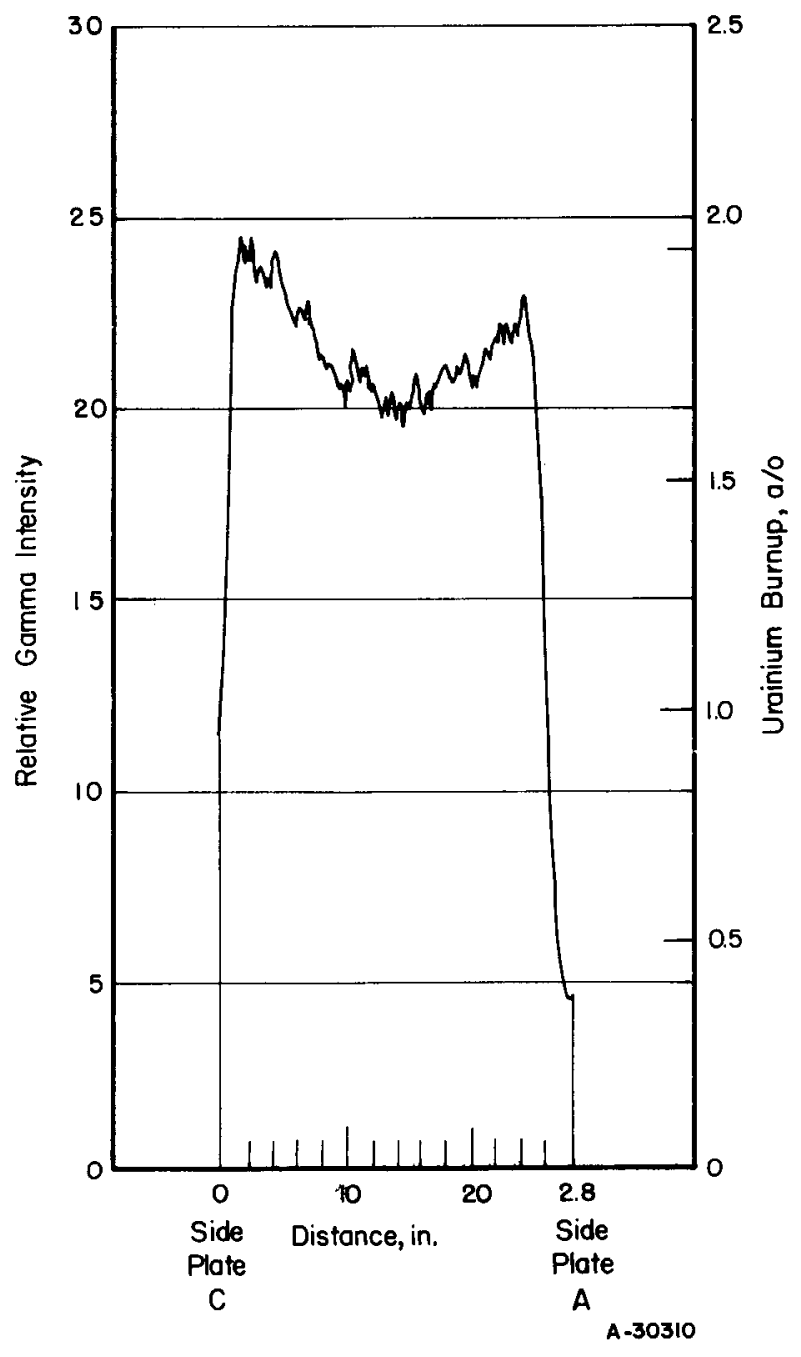

FIGURE 34. TRANSVERSE GAMMA-RAY-ACTIVITY SCAN I OF PLATE 103-2 


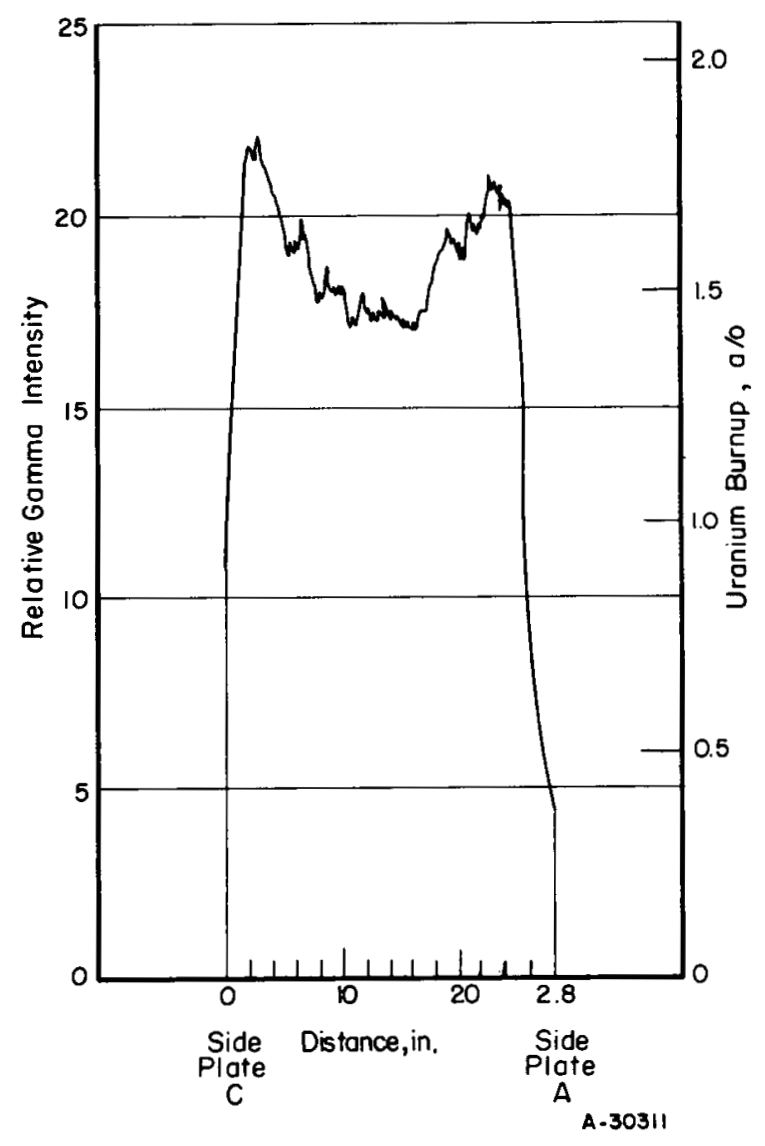

FIGURE 35. TRANSVERSE GAMMA-RAY-ACTIVITY SCAN J OF PLATE 103-2 


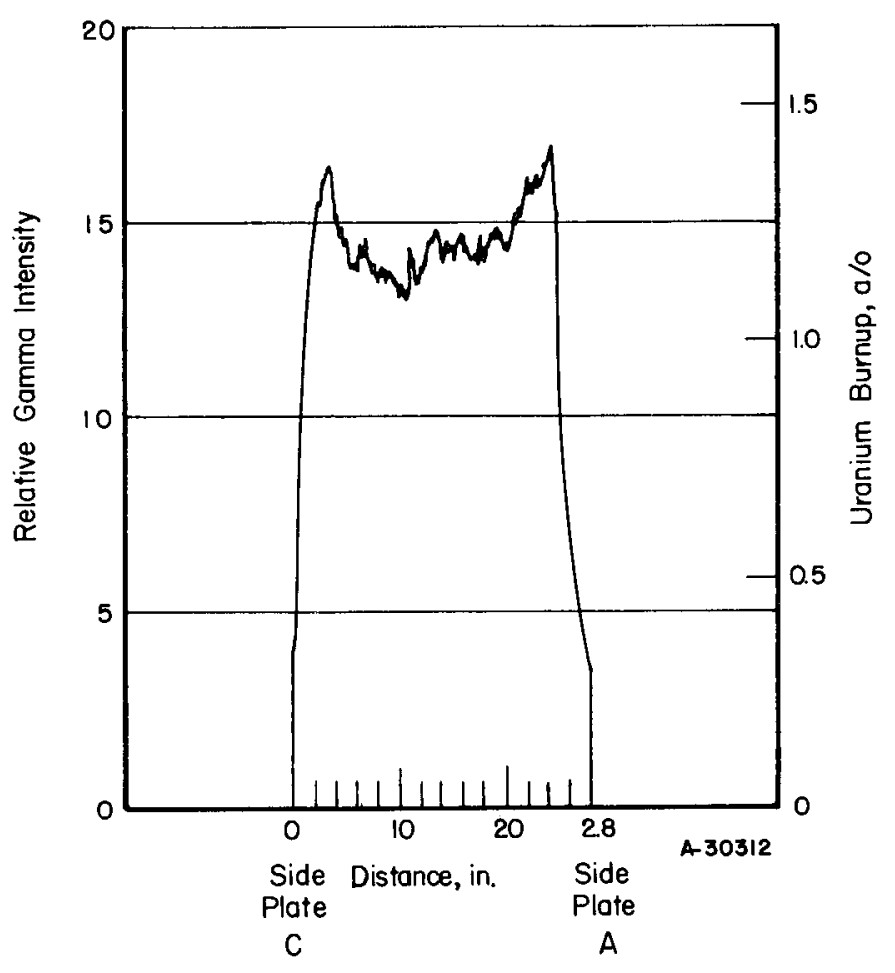

FIGURE 36. TRANSVERSE GAMMA-RAY-ACTIVITY SCAN K OF PLATE 103-2 


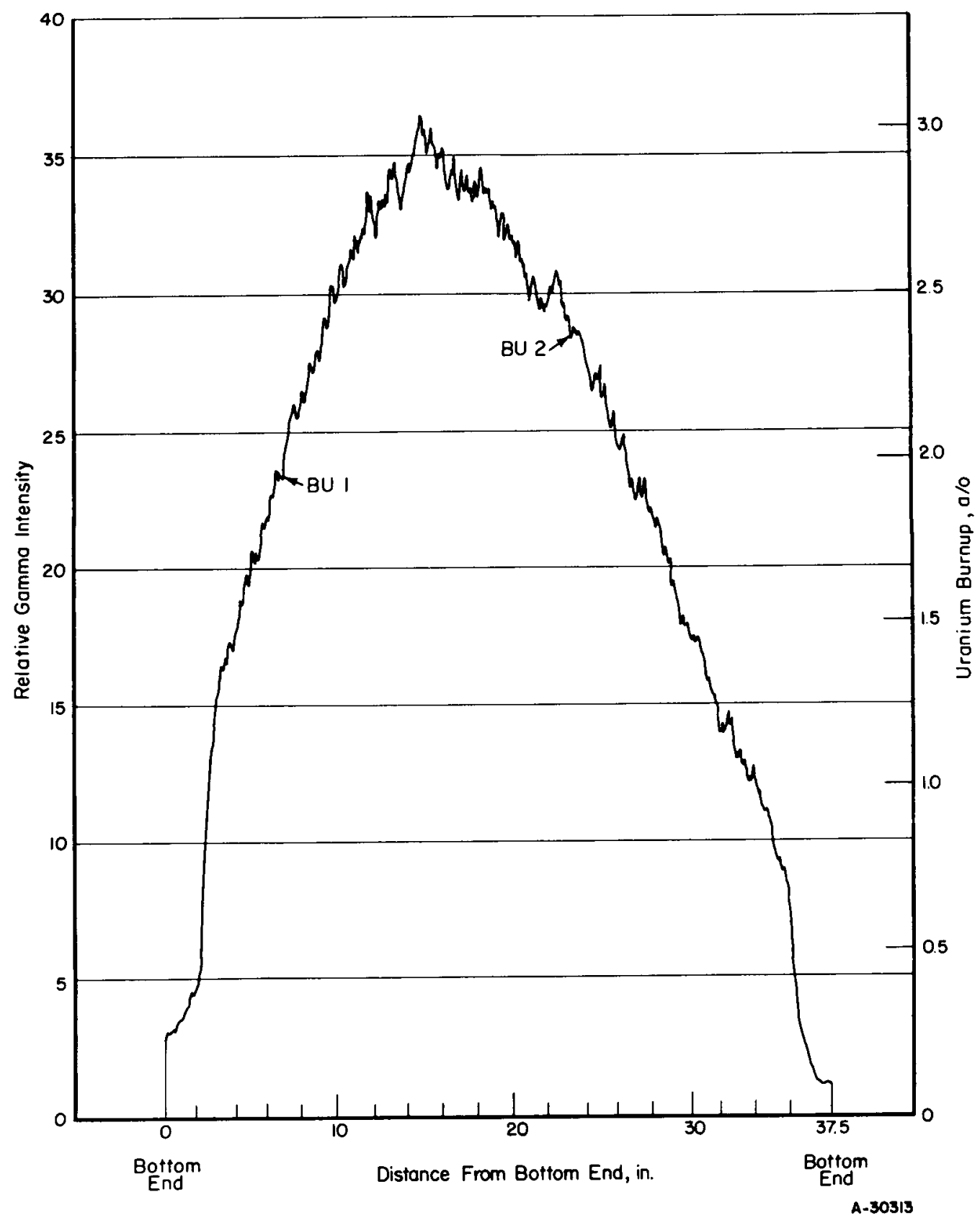

FIGURE 37. LONGITUDINAL GAMMA-RAY-ACTIVIT Y SCAN L AT CENTER LINE OF PLATE 104-2 


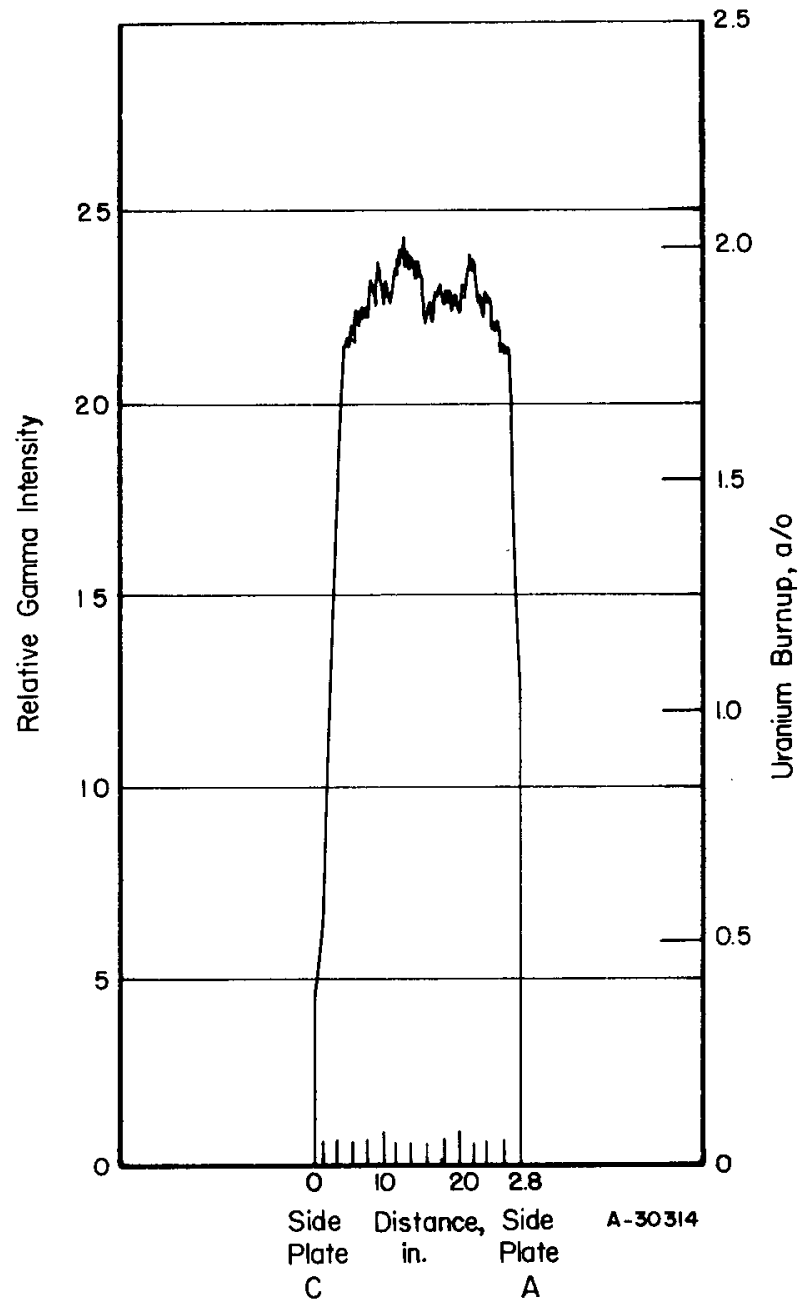

FIGURE 38, TRANSVERSE GAMMA-RAY-ACTIVIT Y SCAN M OF PLATE $104-2$ 


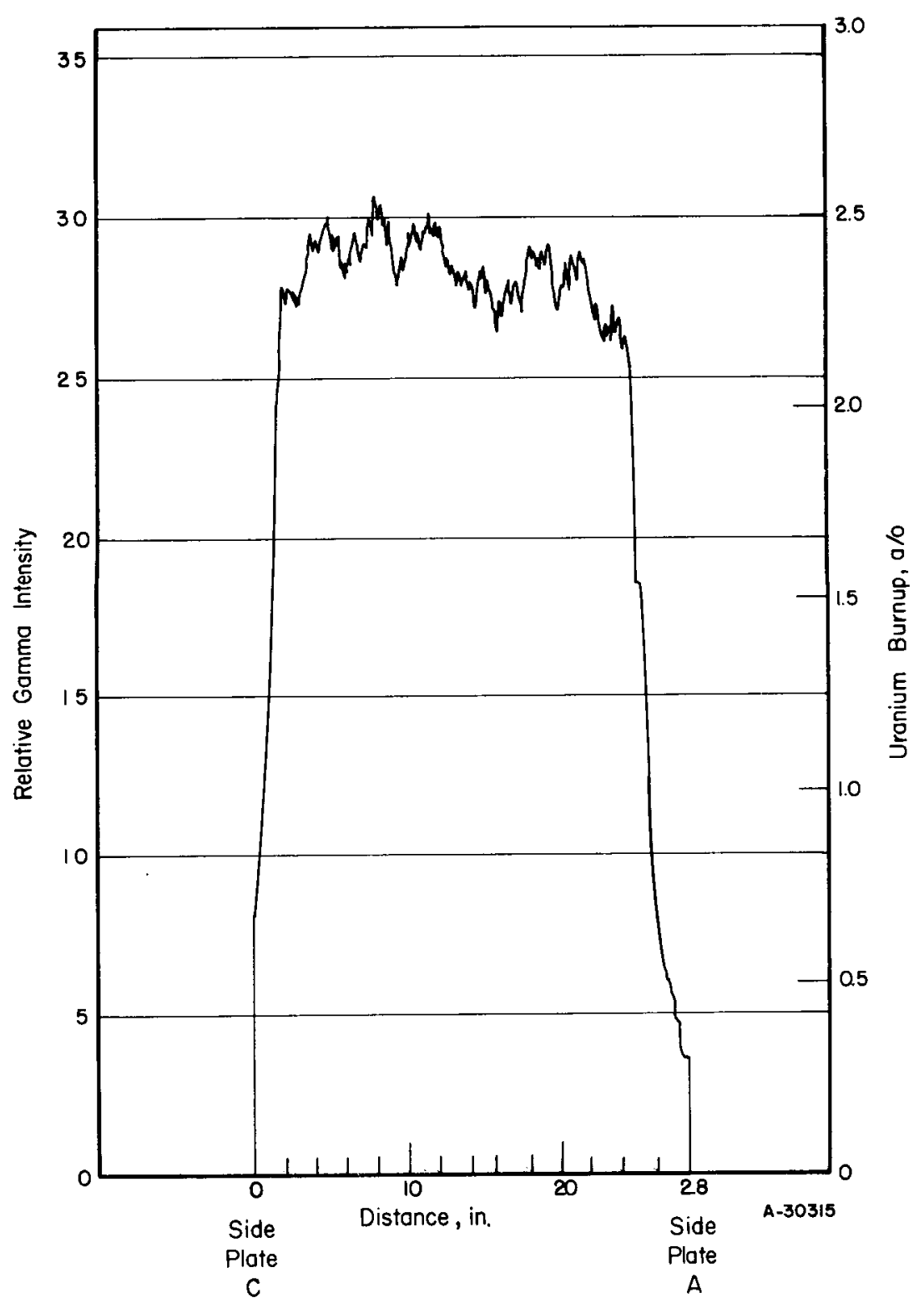

FIGURE 39. TRANSVERSE GAMMA-RAY-ACTIVITY SCAN N OF PLATE 104-2 


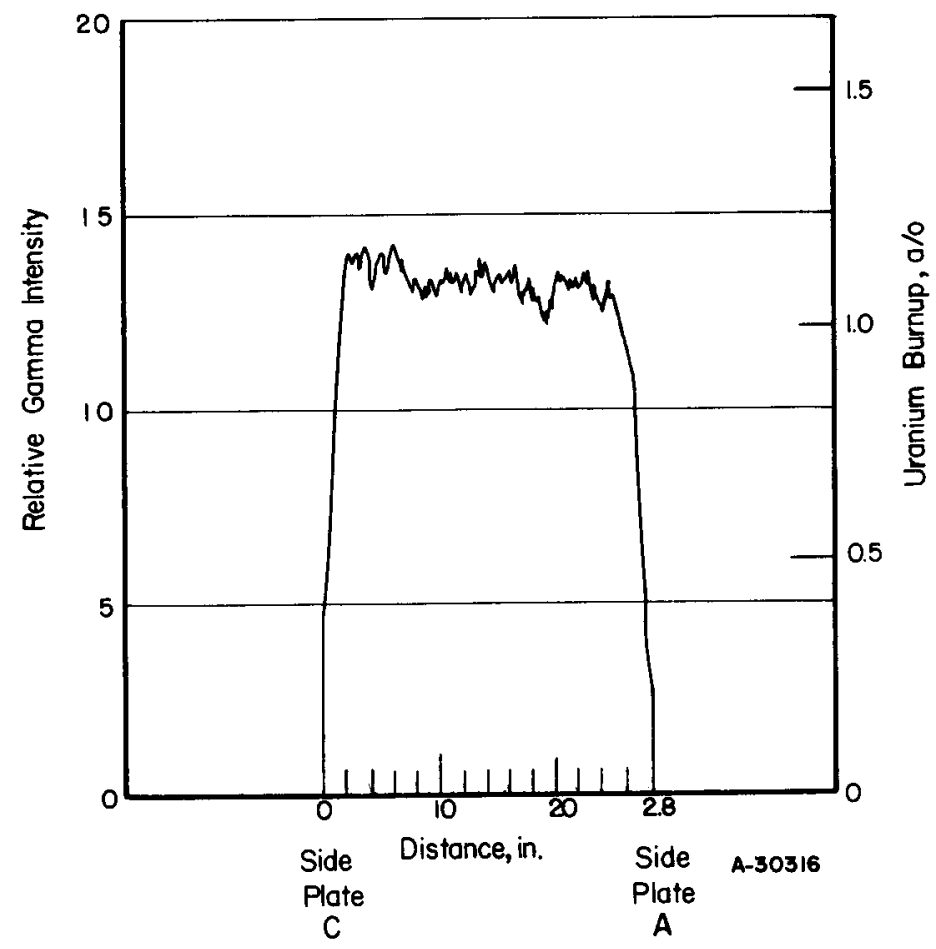

FIGURE 40. TRANSVERSE GAMMA-RAY-ACTIVITY SCAN O OF PLATE 104-2 
The variable-speed motors driving the scanning mechanism were operated at their slowest speed during scanning. This speed was difficult to duplicate from one scan to another, resulting in differences in the base width of the scanning curves. The recorder was operated at its fastest speed. The differences in scanning speed did not affect the relative accuracy of the gamma-intensity measurements, since the time constant of the scintillation detector was set at $0.1 \mathrm{sec}$ during the scans. The transverse scans were normally run at a speed of about $0.3 \mathrm{in}$. per min and the longitudinal scans at about 3.0 in. per min.

Radiochemical Burnup Analyses and Correlation With Gamma-Scan Data

Using the gamma-scan data to select a location on the longitudinal center line of the plate, two 0.25-in.-diameter slugs were punched from each of the three plates. As a recheck on the location of the punchings, the plates were rescanned. The recorded gamma activity decreased almost to background as the hole in the fuel plate passed in front of the attenuation hole, confirming the location of the punchings. The slugs were dissolved and each was analyzed radiochemically for cesium-137 and uranium content. The analysis procedures are outlined in Appendix D. The results of the radiochemical analyses were used to calculate the burnups listed in Table 6 . The relative gamma intensities of the fuel plates obtained from the gamma-scan curves at the same points are also included in this table.

TABLE 6. CORRELATION OF RELATIVE GAMMA ACTIVITIES WITH RESULTS OF THE URANIUM BURNUP ANALYSES

\begin{tabular}{lccccc}
\hline $\begin{array}{c}\text { Fuel } \\
\text { Plate }\end{array}$ & $\begin{array}{c}\text { Burnup } \\
\text { Number }\end{array}$ & $\begin{array}{c}\text { Distance From Bottom } \\
\text { of Fuel Plate(a), in. }\end{array}$ & $\begin{array}{c}\text { Relative(b) } \\
\text { Gamma } \\
\text { Intensity }\end{array}$ & $\begin{array}{c}\text { Uranium } \\
\text { Burnup (b) } \\
\text { a/o }\end{array}$ & $\begin{array}{c}\text { Relative Gamma } \\
\text { Intensity per } \\
\text { a/o Burnup }\end{array}$ \\
\hline $104-1$ & 1 & 3.9 & $22.0(\mathrm{c})$ & 2.29 & 9.6 \\
$104-1$ & 2 & 23.7 & 38.0 & 3.08 & 12.3 \\
$103-2$ & 1 & 15.0 & 20.5 & 1.57 & 13.1 \\
$103-2$ & 2 & 26.2 & 14.5 & 1.28 & 11.3 \\
$104-2$ & 1 & 6.8 & 23.5 & 2.05 & 11.5 \\
$104-2$ & 2 & 23.7 & 28.5 & 2.45 & 11.6 \\
\hline
\end{tabular}

(a) Distance measured from bottom of spacer -pin slot in fuel plates.

(b) Precision estimated to be \pm 10 per cent.

(c) This value was determined from a portion of the gamma-scan curve with a large slope.

The results of the radiochemical burnup analyses are shown in Figure 41 as a function of relative gamma intensity. An average value of $12.0 \pm 0.7$ was calculated for the relative intensity of gamma radiation at 1.0 a/o burnup. The standard deviation of this value was used to indicate the data spread shown in Figure 41 . This curve may be used to estimate the uranium burnup at any location on the scanned fuel plates.

One point obtained from Plate 104-l did not fit the curve. The slug used for the burnup analysis was punched near the end of the plate. The relative intensity of the gamma radiation was changing rapidly over this area, making it difficult to select an 


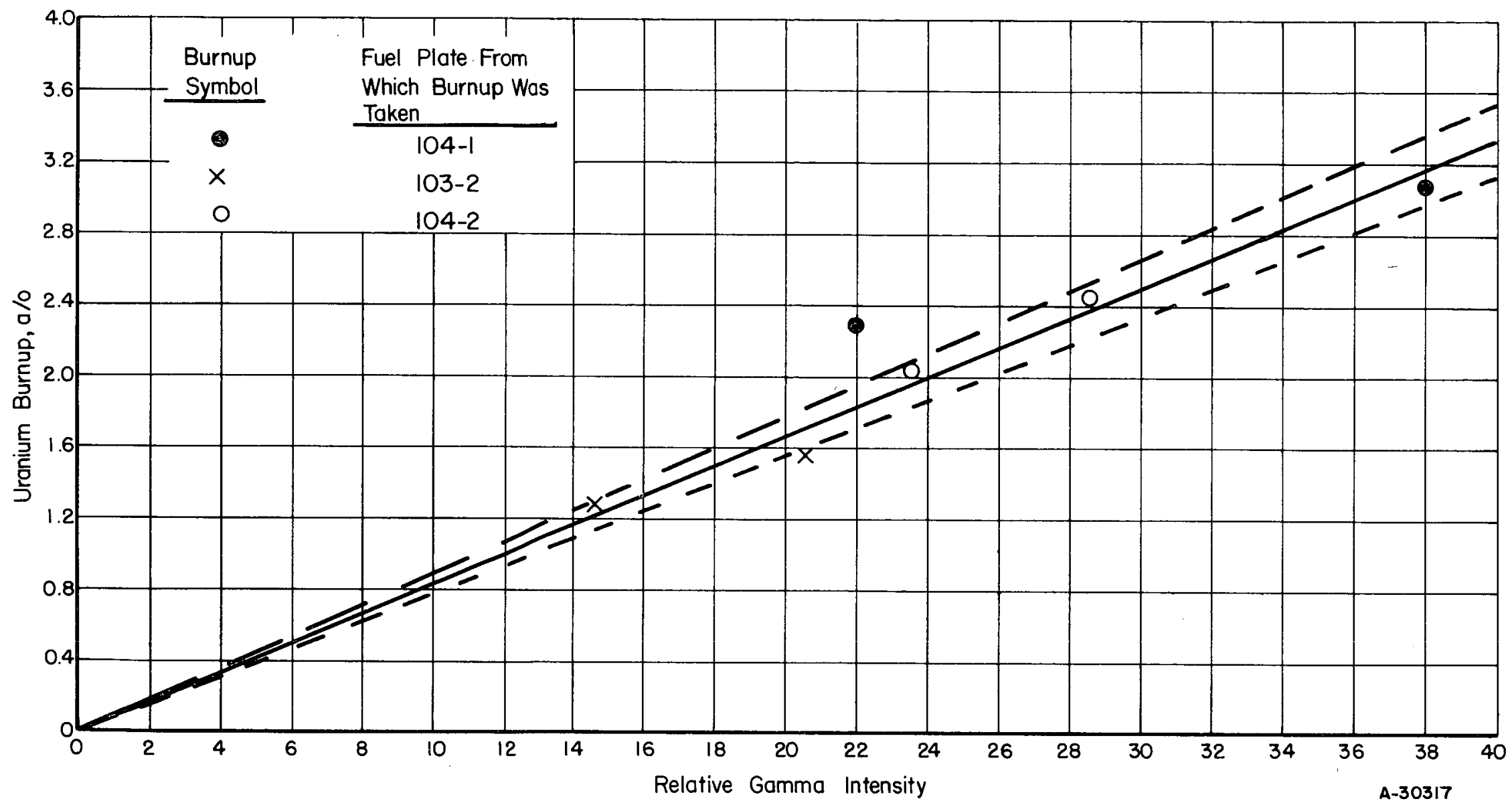

FIGURE 41. CORRELATION OF RELATIVE GAMMA-RAY INTENSITY WITH BURNUP DATA 
exact intensity value at this location. This value for the relative intensity per a/o burnup was so far out of line that it was not used in calculation of the average value mentioned above.

The gamma scan curves were used, in conjunction with the burnup data, to estimate the average burnup of the fuel plates. The results are included in Table 7 . A description of the methods used in treating the gamma scan and burnup data is given in Appendix E.

TABLE 7. ESTIMATED AVERAGE AND MAXIMUM FUEL-PLATE BURNUPS ALONG THE DESIGNATED GAMMA SCAN

\begin{tabular}{|c|c|c|c|c|c|}
\hline \multirow{2}{*}{$\begin{array}{l}\text { Fuel } \\
\text { Plate }\end{array}$} & \multirow{2}{*}{$\begin{array}{l}\text { Gamma } \\
\text { Scan }\end{array}$} & \multirow{2}{*}{$\begin{array}{c}\text { Location of } \operatorname{Scan}(a), \\
\text { in. from } \\
\text { bottom of plate }\end{array}$} & \multicolumn{2}{|c|}{$\begin{array}{c}\text { Estimated Burnup, } \\
a / 0\end{array}$} & \multirow{2}{*}{$\begin{array}{c}\text { Location of Maximum } \\
\text { Burnup, in. }\end{array}$} \\
\hline & & & $\overline{\text { Average }}$ & $\overline{\text { Maximum }}$ & \\
\hline \multirow[t]{4}{*}{$104-1$} & C & Longitudinal center line & 2.5 & 3.7 & 14. 9 from plate bottom $(a)$ \\
\hline & $D$ & Transverse, 6.7 & 2.5 & 2.7 & 0.31 from Side Plate $C$ \\
\hline & $\mathrm{E}$ & Transverse, 18.4 & 3.5 & 3.7 & 0.31 from Side Plate $C$ \\
\hline & $\mathrm{F}$ & Transverse, 29.3 & 2.1 & 2.2 & 0.89 from Side Plate $C$ \\
\hline \multirow[t]{5}{*}{$103-2$} & G & Longitudinal center line & 1.1 & 1.7 & 14.2 from plate bottom (a) \\
\hline & $\mathrm{H}$ & Transverse, 7.3 & 1.3 & 1.5 & 0.39 from Side Plate $C$ \\
\hline & I & Transverse, 14.2 & 1.8 & 2.0 & 0.19 from Side Plate $C$ \\
\hline & $J$ & Transverse, 20.7 & 1.5 & 1.8 & 0.24 from Side Plate C \\
\hline & $\mathrm{K}$ & Transverse, 25.7 & 1.2 & 1.4 & 2. 36 from Side Plate $C$ \\
\hline \multirow[t]{4}{*}{$104-2$} & $L$ & Longitudinal center line & 1.9 & 3.0 & 14. 7 from plate bottom(a) \\
\hline & M & Transverse, 6.6 & 1.9 & 2.0 & 1. 17 from Side Plate C \\
\hline & $\mathrm{N}$ & Transverse, 23.2 & 2.4 & 2.5 & 0.80 from Side Plate C \\
\hline & $\mathrm{O}$ & Transverse, 32.2 & 1.1 & 1.2 & 0.62 from Side Plate $C$ \\
\hline
\end{tabular}

(a) Distance measured from bottom of spacer-pin slot in fuel plates.

Measurements of Fuel-Plate and Organic-

Residue Thicknesses

Measurements of the fuel-plate thickness were made in order to obtain information on the swelling of the plates during irradiation. The thickness of the organic residue was also of interest since it affected the heat-transfer properties of the plates and the fuel element as a whole. The nominal plate thickness before irradiation was $0.030 \mathrm{in.}$, with a manufacturing tolerance of $0.001 \mathrm{in}$.

Several attempts were made to measure the plate and residue thicknesses with flat-anvil micrometer. The composite thickness was measured followed by attempts to remove the organic residue, first by solvents and then by buffing with a wire wheel, followed by thickness measurements of the cleaned plate. Several solvents were tried with very little success as described in Appendix C. Finally it became necessary to resort to buffing with a stainless steel wire wheel. 
TABLE 8. FUEL-PLATE-THICKNESS MEASUREMENTS

\begin{tabular}{|c|c|c|c|c|c|}
\hline \multirow[b]{2}{*}{ Condition of Plate Surface } & \multicolumn{5}{|c|}{ Plate Thickness at Four Points in I-In. Circle, in } \\
\hline & 1 & 2 & 3 & 4 & Average \\
\hline \multicolumn{6}{|c|}{ Plate 104-7, 6 In. From Bottom End } \\
\hline Before buffing & 0.0304 & 0.0301 & 0.0298 & 0.0296 & 0.0300 \\
\hline After buffing Side 1 (a) & 0.0300 & 0.0294 & 0.0296 & 0.0291 & 0.0295 \\
\hline After buffing Side $2(\mathrm{~b})$ & 0.0286 & 0.0283 & 0.0290 & 0.0288 & 0.0287 \\
\hline After second buffing of Side 1 (a) & 0.0284 & 0.0292 & 0.0285 & 0.0287 & 0.0287 \\
\hline
\end{tabular}

Plate 104-7, 19 In. From Bottom End

Before buffing

After buffing Side $1^{(a)}$

After buffing Side 2 (b)

After second buffing of Side $1(a)$
0.0314

0.0291

0.0328

0.0288

0.0291

0.0286

0.0285

0.0281
0.0294

0.0293

0.0282

0.0287
0.0282

0.0298

0.0284

0.0285
0.0304

0.0293

0.0285

0.0285

Plate 104-7, 32 In. From Bottom End

\section{Before buffing}

After buffing Side 1 (a)

After buffing Side $2(b)$

After second buffing of Side la)
0.0290

0.0287

0.0312

0.0294

0.0283

0.0287

0.0286

0.0284

0.0295

0.0291

0.0288

0.0287
0.0298

0.0291

0.0285

0.0288
0.0299

0.0291

0.0286

0.0286

Plate 103-1, 6 In. From Bottom End

\section{Before buffing}

After buffing Side $1^{(a)}$

After buffing Side $2^{(b)}$

After second buffing of Side ${ }_{1}^{(a)}$
0.0319

0.0305

0.0301

0.0302
0.0318

0.0309

0.0303

$\begin{array}{ll}0.0301 & 0.0291\end{array}$

0.0325

0.0302

0.0294

0.0291

0.0330

0.0306

0.0323

0.0290

0.0295

0.0305

0.0297

0.0297

Plate 103-1, 19 In. From Bottom End

\section{Before buffing}

After buffing Side 1 (a)

After buffing Side 2 (b)

After second buffing of Side 1 (a)
0.0294

0.0292

0.0278

0.0280
0.0309

0.0290

0.0284

0.0286
0.0298

0.0287

0.0281

0.0279
0.0292

0.0294

0.0288

0.0286
0.0298

0.0291

0.0283

0.0283

Plate 103-1, 32 In. From Bottom End

Before buffing After buffing Side l(a) After buffing Side $2(b)$ After second buffing of Side $1(a)$
0.0300

0.0305

0.0294

0.0295
0.0310

0.0302

0.0293

0.0297
0.0312

0.0308

0.0296

0.0291
0.0314

0.0302

0.0292

0.0290
0.0309

0.0304

0.0294

0.0294

(a) Side 1 is the side of the fuel plate facing End Plate D.

(b) Side 2 is the side of the fuel plate facing End Plate $B$. 
The thickness of Plates 104-7 and 103-1 was measured in several areas. An average value for the thickness was obtained from a group of four measurements within a 1-in. circle. The area included in and surrounding the circle was then buffed with the wire wheel. Thickness measurements were then repeated over the same area as before. These data are included in Tables 8 and 9. The thickness of the organic residue was considered to be the difference between the average measured thickness of the plate before and after cleaning. Since the variation among the four readings in each group was approximately equal to the difference between the averages, as shown in Table 8 , the apparent residue thicknesses are considered to be inconclusive. The variations in the readings are due in part to the manufacturing tolerance of $\pm 0.001 \mathrm{in.}$ in the plate thickness, and to the error of about $\pm 0.0002 \mathrm{in.}$ in the measurements.

\section{TABLE 9. APPARENT RESIDUE THICKNESSES AS DETERMINED BY MICROMETER MEASUREMENTS(a)}

\begin{tabular}{|c|c|c|c|c|}
\hline \multirow{3}{*}{$\begin{array}{c}\text { Distance } \\
\text { from Bottom } \\
\text { End of Plate, } \\
\text { in. }\end{array}$} & \multicolumn{4}{|c|}{ Residue Thickness at Point Indicated, in. } \\
\hline & \multicolumn{2}{|c|}{ Fuel Plate 104-7 } & \multicolumn{2}{|c|}{ Fuel Plate 103-1 } \\
\hline & Side $1(b)$ & Side $2(c)$ & Side $1(b)$ & Side $2(\mathrm{c})$ \\
\hline 6 & 0.0005 & 0.0008 & 0.0018 & 0.0008 \\
\hline 19 & 0.0011 & 0.0008 & 0.0007 & 0.0008 \\
\hline 32 & 0.0008 & 0.0005 & 0.0005 & 0.0010 \\
\hline
\end{tabular}

(a) It is not believed these data are significant. See text.

(b) Side 1 is the side of the fuel plate facing End Plate $D$.

(c) Side 2 is the side of the fuel plate facing End Plate B.

During the course of subsequent metallographic examinations, which were planned after the plate-thickness measurements were completed, the organic-residue thickness was measured optically. The measurements were made on sections cut from plates 104-1 and 104-12. The locations from which these sections were removed from the fuel plates are described in a subsequent section on the metallographic work. From these measurements, the average residue thickness was determined to be 0.00025 in., the maximum 0.00037 in., and the minimum 0.00012 in.

\section{Collection of the Organic Residue}

During the course of the examination of the fuel plates it became evident that it would be desirable to know the composition of the organic residue. Several attempts were made to remove the residue by washing and scraping. Finally, about $0.5 \mathrm{~g}$ of the powdered residue was collected by punching 0.25-in. -diameter slugs from Plate 103-15 and collecting the residue chipped from the slugs. The collected residue was shipped to AI for chemical analysis. 
Metallographic Examination

After discovery of the pitted areas on Plate 104-1, and the difficulties encountered in measuring the organic-residue thickness, it was decided to perform metallographic examinations on two fuel plates, 104-1 and 104-12. Plate 104-1 was sectioned to permit examination of a pitted area, while Plate 104-12 was sectioned to permit the examination of undisturbed organic residue.

The selected areas were sheared from both plates. An air-cooled abrasive cutoff wheel was then used to prepare the metallographic specimen. The section removed from Plate 104-l was approximately $10 \mathrm{in}$. from the numbered end near the center of the plate. The section removed from Plate 104-12 was approximately 12 in. from the numbered end near the middle of the plate.

The metallographic specimens were mounted in Bakelite, ground on 240-, 400-, and 600-grit silicon carbide grinding disks, and polished with $1-\mu$ aluminum oxide abrasive, Linde A, and finally Linde B. The polishing was performed on vibrator polishers. The specimens were examined in the polished state and then etched by swabbing with a solution of 5 parts glycerin, 5 parts hydrochloric acid and 1 part nitric acid. The etched surfaces were examined and photomicrographs were taken of representative areas of the core and cladding.

Specimen 104-12 was inspected in the polished condition to examine the residue layer on the fuel plate. Residue-thickness measurements taken along the entire length of the exposed edges indicated that the average thickness was 0.0025 in. The maximum thickness observed was 0.00037 and the minimum was 0.00012 in. A photomicrograph of a typical portion of the residue layer is presented in Figure 42. The dark band between the residue layer and the stainless steel cladding is a void space. This void was probably formed by separation of the residue from the steel during the sectioning of the specimen from the fuel plate. The residue layer evident on Specimen 104-12 was not observed on Specimen 104-1.

Plate 104-1, from which the metallographic specimen was sectioned, was used to develop techniques for removing the residue layer. The specimen was primarily studied to ascertain the cause of the macro pits observed during the visual examination of the fuel plate. Representative photomacrographs of these pits are presented in Figures 22 and 23. Figures 43 and 44 are representative areas showing cross sections of the se pits. Figure 44 shows an area included in Figure 43 at a higher magnification. The blurred portion of the photomicrographs at the cladding-bakelite interface is the result of a rounding-off of the specimen edge during polishing. The large black area at the lower left of Figures 43 and 44 is a field marker. The minimum cladding thickness of the bottom of the pits was approximately 0.0020 inches. The surface of the cladding in these pits appeared normal and no evidence of carburization or corrosive attack was observed. Figure 45 shows another pitted area from Specimen 104-1 at a magnification of 250X. A photomicrograph of an unpitted edge of Specimen 104-1 is shown in Figure 46 for comparison. Again the rounded cladding-Bakelite interface makes focus at that point difficult. The cladding thickness in the unpitted areas averaged about 0.006 in. Small micro sized pits were observed in the surface of the cladding on Specimen 104-12. Typical examples of sections through these pits in the surface of the cladding of Specimen 104-12 are shown in Figures 47, 48, and 49. The depth of the deepest pit observed was approximately $0.0003 \mathrm{in.} \mathrm{Evidence} \mathrm{of} \mathrm{carburization} \mathrm{or} \mathrm{oxidation} \mathrm{in} \mathrm{the} \mathrm{se} \mathrm{areas} \mathrm{was}$ 


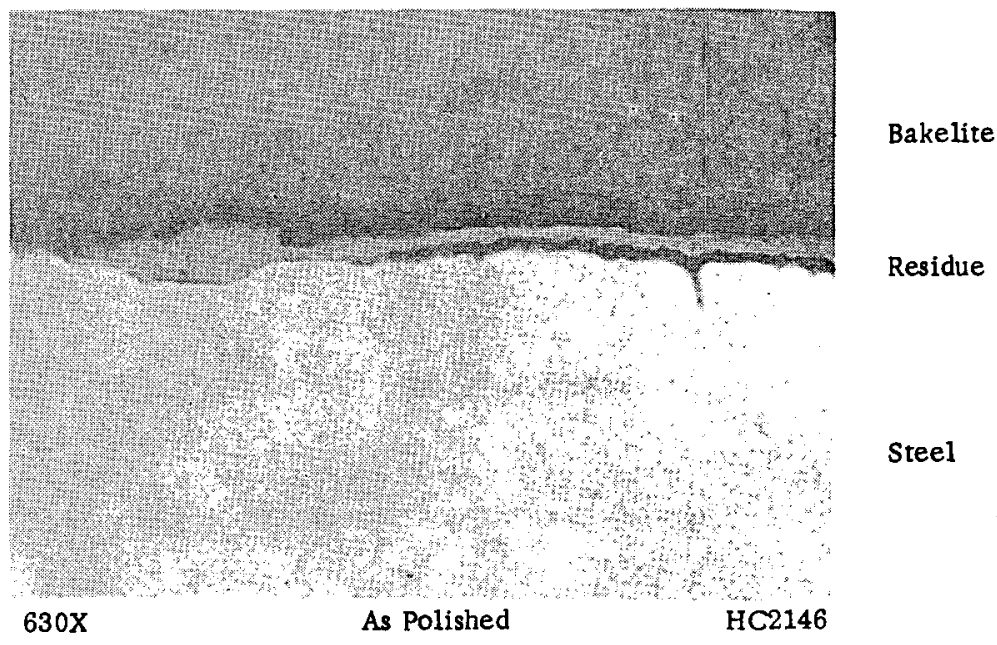

FIGURE 42. A TYPICAL PORTION OF THE RESIDUE LAYER ON PLATE 104-12

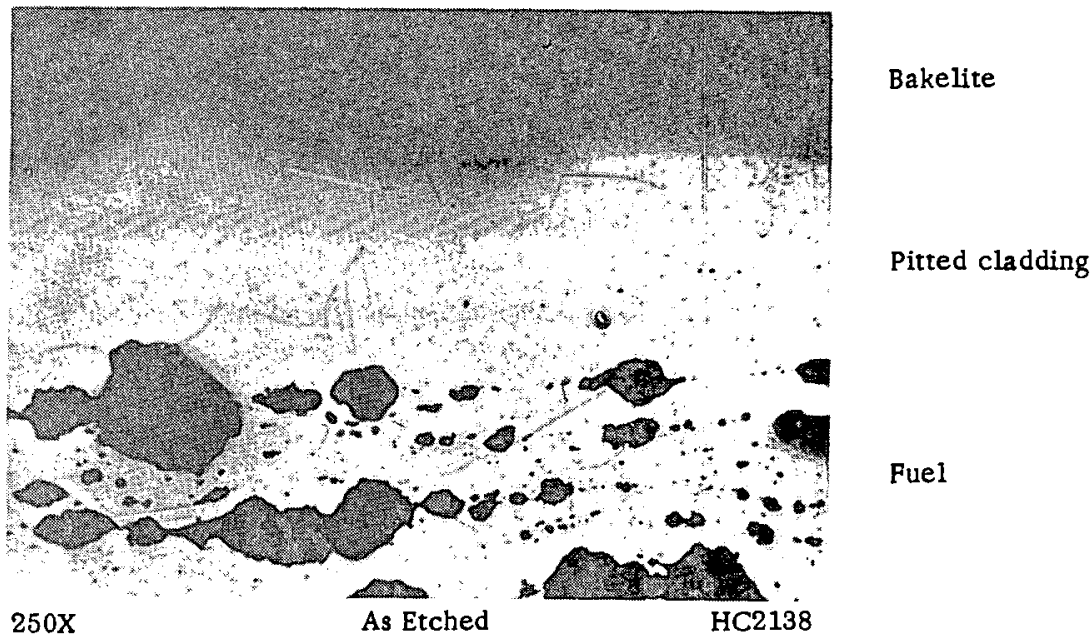

FIGURE 43. SECTION THROUGH PITTED AREA IN PLATE 104-1 Black spot at left is "field" marker.

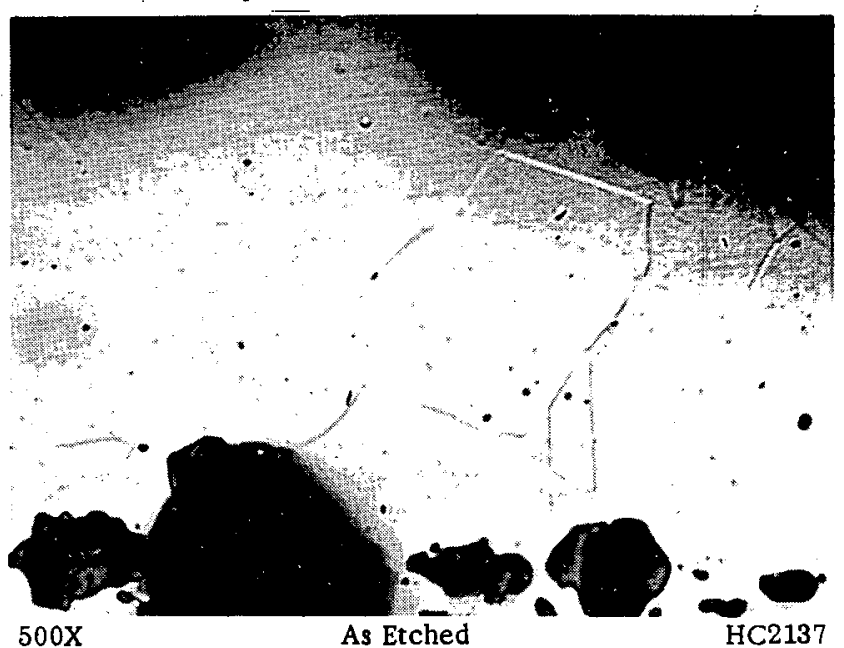

FIGURE 44. HIGHER MAGNIFICATION PHOTO OF AREA SHOWN IN FIGURE 43 Note "black" field marker. 


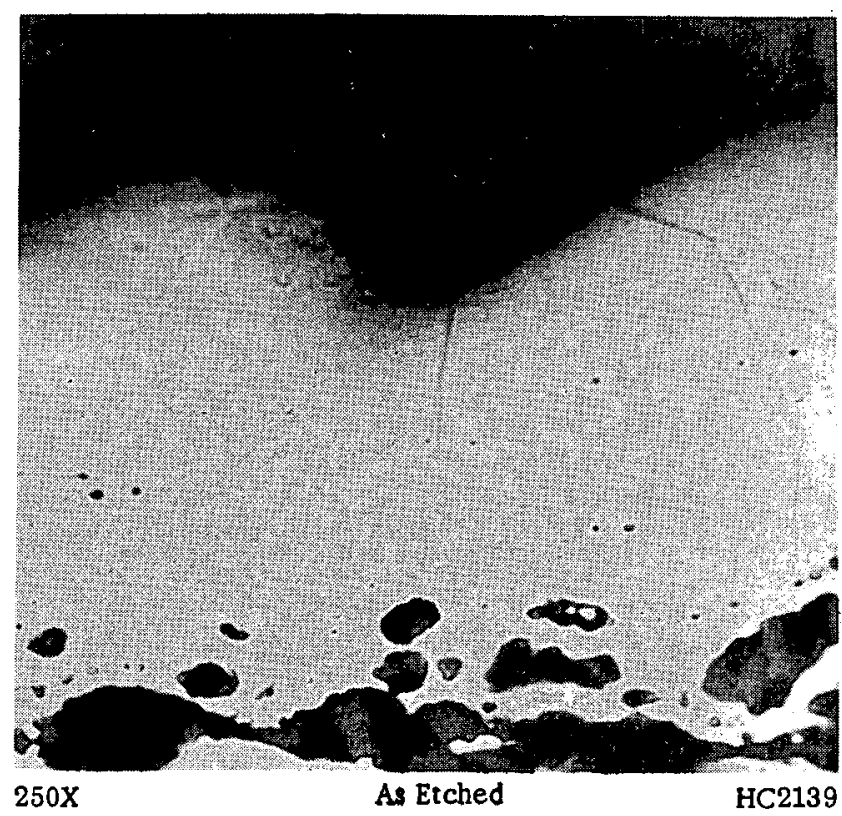

FIGURE 45. CROSS SECTION OF ANOTHER TYPICAL PIT IN PLATE 104-1

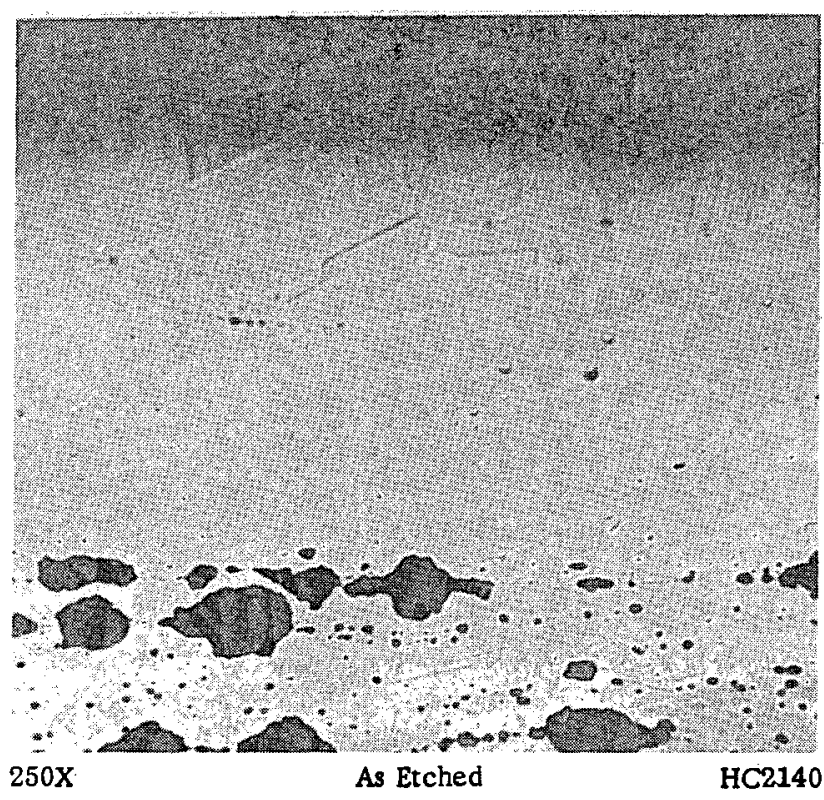

FIGURE 46. TYPICAL UNPITTED AREA OF PLATE 104-1

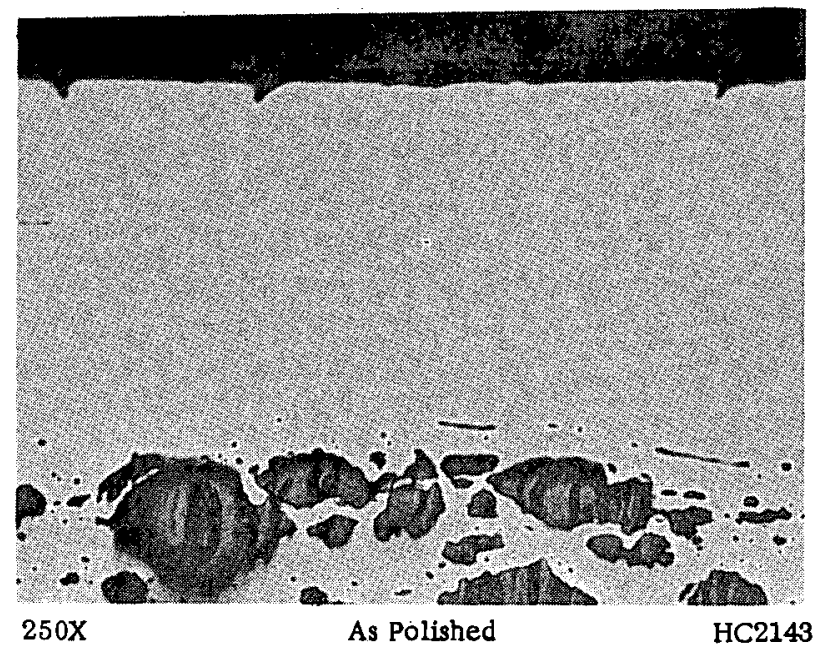

FIGURE 47. MICRO-SIZED PITS IN THE CLADDING OF PLATE 104-12 
not observed. The structure of the cladding shown in Figures 48 and 49 is typical of the structure of Type 304 stainless steel. The dark spots are inclusions of undetermined nature.

Examination of the core material indicated that the fabrication cracks in the $\mathrm{UO}_{2}$ particles had not healed during irradiation. Figure 50 illustrates a typical area in the core of Plate 104-12.

\section{DISCUSSION OF RESULTS}

The results of the postirradiation examination generally indicate that structurally Element OMRE-3 was affected very little by either the radiation or the organic coolant environment. The average counterclockwise twist in the element between the first and twelfth tabs, counting from the bottom end, was determined to be 0.010 radian. This is equivalent to an average twist of 0.004 radians per ft. Although preirradiation data for twist in the element were made available to Battelle, the direction of twist and the length over which the twist was measured were not clearly defined. It appears that the measured twist in the element after irradiation was probably insignificant, considering the manufacturing tolerances.

The data indicate some trends in the distortion of the side and end plates of the fuel element. End Plates B and D tended to bow inward toward the center of the element along the lower half of the element-box assembly. However, along the upper half of the element-box assembly, the end plates tended to bow outward. The preirradiation data available indicate that the two plates were parallel to within 0.021 in. while inspection of Figure 10 shows a parallelism to within $0.033 \mathrm{in}$. after irradiation. This is an average separation of the end plates after irradiation of 0.012 in.; however, the maximum separation occurring at a point was approximately $0.034 \mathrm{in}$.

The distortion of Side Plates $A$ and $C$ exceeded that of End Plates B and D. The two side plates tended to bow away from the center of the element, achieving a maximum distortion after irradiation of approximately 0.062 in. near midlength. The side plates were confined in the amount of distortion they experienced by the tabs, as shown in Figure 9. The location of each tab is marked by a depression in the side plate profiles.

Measurements of the channel spacing between the fuel plates indicated a maximum closure of $0.013 \mathrm{in.}$ This was a reduction in passage cross section of 11.0 per cent at this point. Generally, 85 per cent of the measurements indicate a reduction in passage cross section at specific points of less than 5 per cent. It should be remembered, however, that the manner in which the fuel plates are loosely held between the side plates produces significant errors in the plate-spacing measurements. Therefore, it is estimated that the average reduction in coolant passage cross section was probably nearer 2 per cent or less.

Visual inspection of the coolant channels in the element indicated that they were free of major fouling or obstructions. However, a thin layer of residue from the degradation of the organic coolant was deposited over all the fuel element. The residue was tenacious and difficult to remove in most instances. The residue was determined to have a thickness of 0.0005 in. in one location on the exterior of the fuel-element box- 


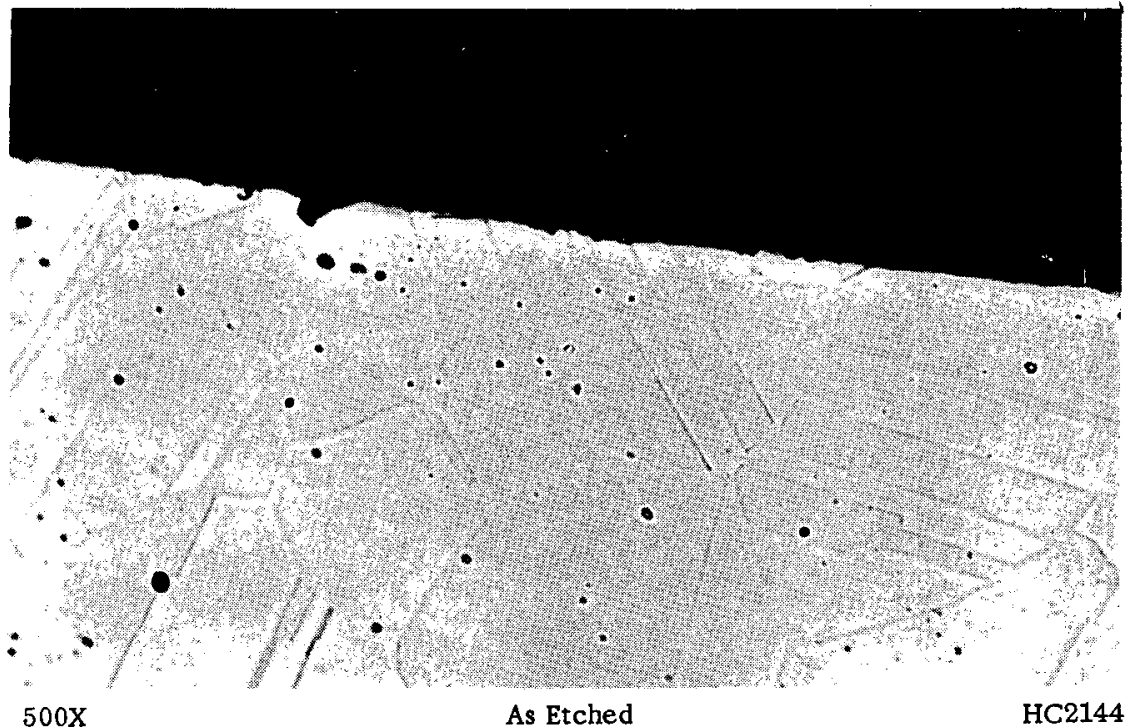

FIGURE 48. CLADDING STRUCTURE AND MICRO-SIZED PITS IN SURFACE OF CLADDING OF PLATE 104-12

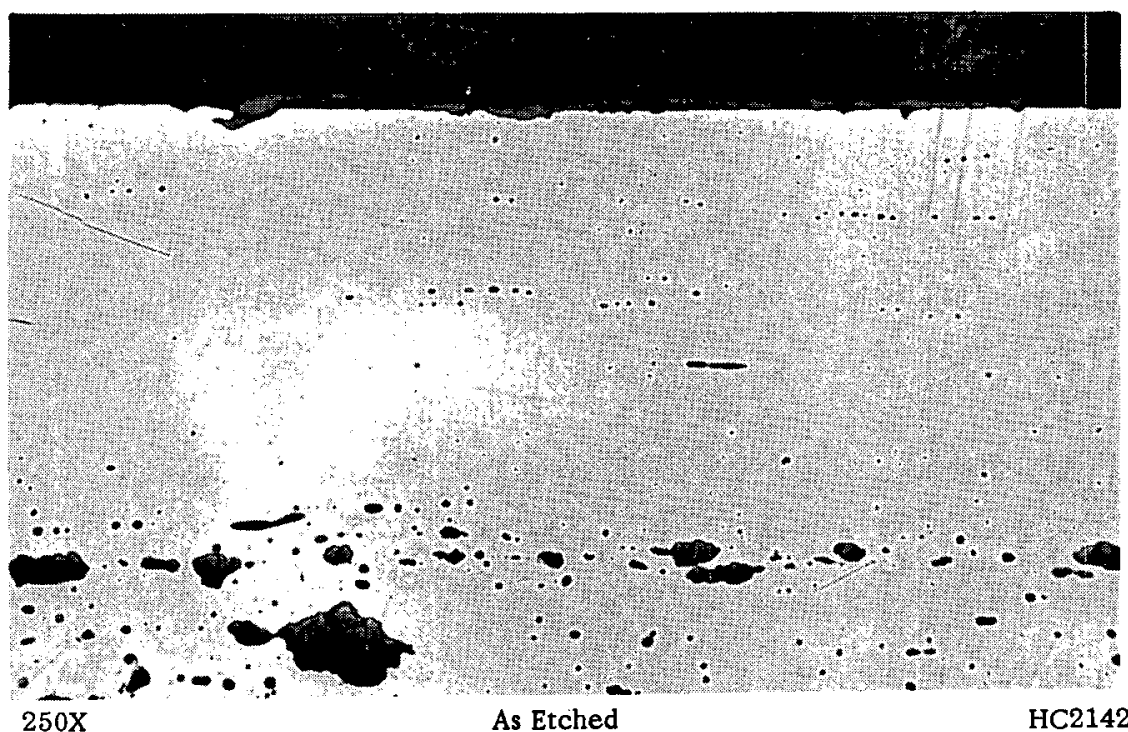

FIGURE 49. CORE AND CLADDING STRUCTURE AND MICROSIZED PITS IN SURFACE OF CLADDING OF PLATE 104-12
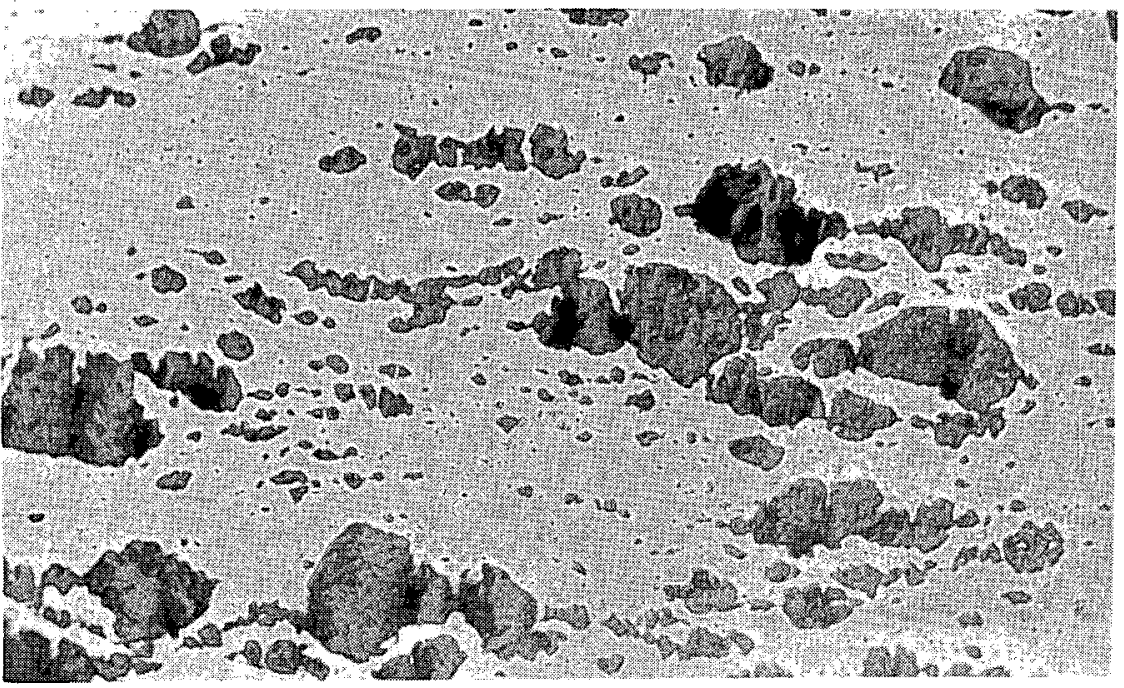

FIGURE 50. APPEARANCE OF A REPRESENT ATIVE AREA OF CORE OF PLATE 104-12 
assembly. On the other hand, the thickness of the residue on the fuel plates was measured by metallography to be 0.00012 to 0.00037 in.

The data obtained from the gamma scans of the three fuel plates were used to develop the plate burnup profiles shown in Figure 51. Since burnups in excess of about $2.0 \mathrm{a} / 0$ did not occur in the middle plate, it is difficult to estimate the burnup profiles of the unscanned plates. It is suggested that in future examinations at least every other fuel plate be scanned in order to give a complete burnup profile of the element. As expected, the data indicate that the burnup of uranium was higher in the outer fuel plates. In addition, the burnup at the edges of the inner fuel plate was found to be higher than in the center of the plates. Comparison of the relative gamma activities of the three plates also indicates that the burnup of the fuel plates was higher adjacent to Side Plate $\mathrm{C}$ and End Plate D of the fuel-element box. This may indicate the orientation of the fuel element in the reactor core. However, a control-rod position adjacent to element OMRE-3 probably caused a distorted flux pattern, as is evidenced in the burnup profile of Plate 104-1.

The approximate burnup of the fuel plates at any point on its gamma-ray-activity curve, can be obtained by making use of Figure 41 or the respective curve. The average uranium-burnups along the center line of Plates 104-1, 103-2, and 104-2 were calculated to be $2.5,1.1$, and 1.9 a/o, respectively. By combining curves in both the longitudinal and transverse directions for each plate, it is possible to obtain an approximate three-dimensional profile plane of burnup for each plate. Making use of the approximate burnup profile, the estimated over-all uranium burnup for Plates 104-1, 103-2, and 104-2 was 2.4,1.1, and 1.8 , a/o, respectively.

A comparison of the dimensional profiles and the gamma-ray-activity curves shows little or no correlation. No definite correlation can be derived between the fuel plate spacing and the gamma-ray activity or burnup. Apparently, the small amount of distortion that occurred in the element during irradiation was caused by relief of stresses formed during fabrication of the element.

The fuel plates were generally in excellent condition. Only one defected area was observed. The defects were in the form of pits located in an area approximately $10 \mathrm{in}$. from the bottom end of Plate 104-1. The pits were irregular in size and shape, with the largest being about $0.030 \mathrm{in.}$ in diameter. A metallographic examination of the fuel plate in the pitted area indicated that the pits extended about two-thirds of the way through the cladding. There was no evidence of carburization of the cladding in the pitted area. It is probable that the pits were formed during fabrication of the plates.

The metallographic examination of the fuel indicated that the $\mathrm{UO}_{2}$ particles were not swollen or cracked. The matrix material was also examined and found free of cracks or other radiation-induced defects. The plate-thickness measurements also indicated that the fuel plates did not swell.

The residue-layer thickness calculated from differential micrometer-caliper measurements is questionable. The average measured residue thicknesses appear consistent. However, the variation in the four micrometer measurements averaged for the residue-thickness value at one point varied as much as three times the calculated value of the residue thickness at that point. This can be partly attributed to the method of measuring the residue-layer thickness and partly to the manufacturing tolerances of the fuel plates. The tolerances were $\pm 0.001 \mathrm{in}$. which is in the order of magnitude of the thickness values obtained. 

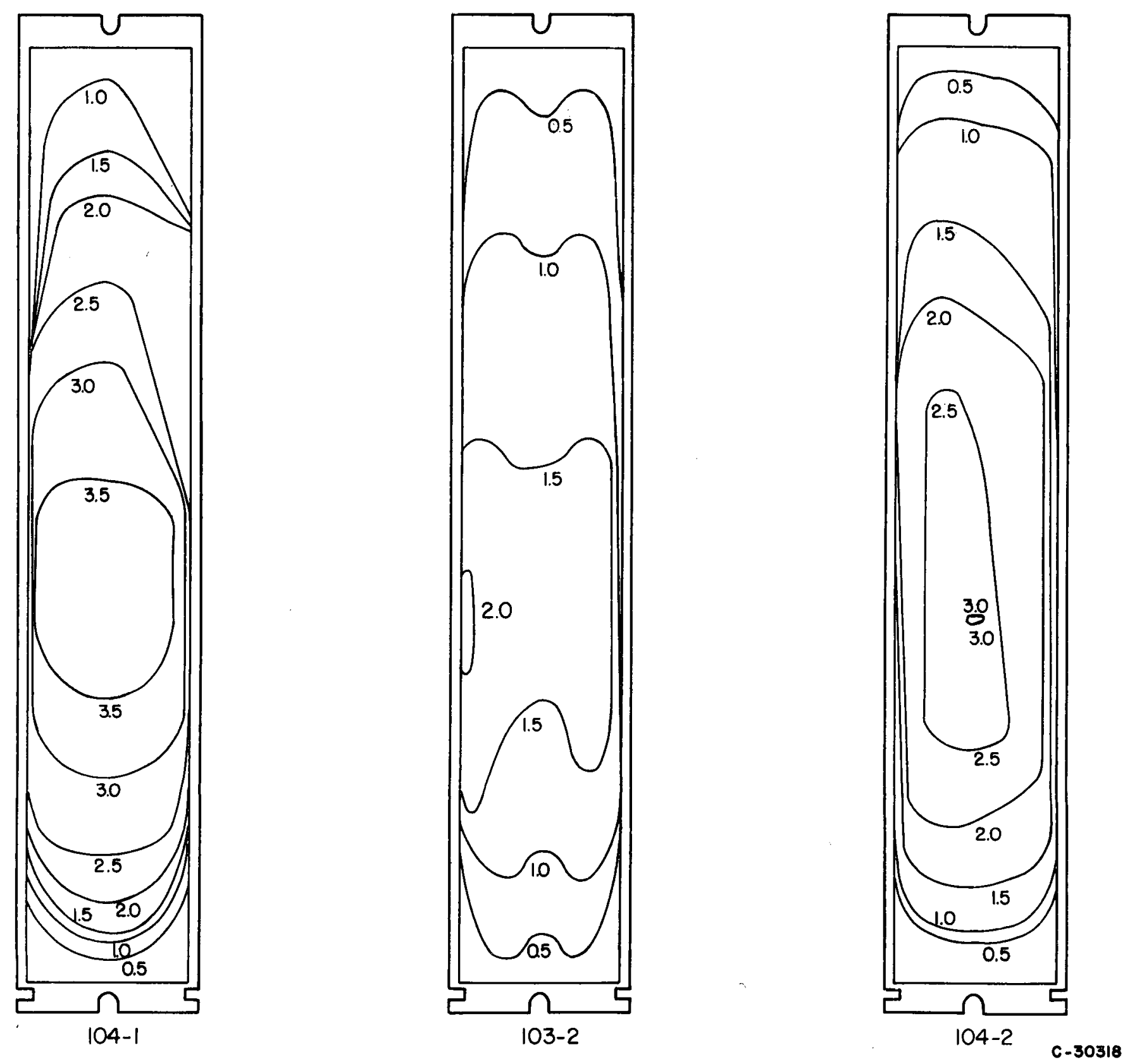

FIGURE 51. BURNUP PROFILES OF T HREE FUEL PLATES 
The residue-layer thickness was also measured during the metallographic examination. The average residue thickness obtained by this method was 0.00025 in. A maximum thickness of $0.00037 \mathrm{in.}$ and a minimum thickness of $0.00012 \mathrm{in.}$ was observed.

\section{EVALUATION}

The results of the postirradiation examination of Element OMRE-3 are generally encouraging to the organic moderated reactor concept. The organic moderator apparently did not produce any corrosion difficulties. The lack of heavy deposits of organic residues or obstructions in the coolant channels of the fuel element indicates the suitability of the Santowax OM moderator-coolant. As would be expected at the burnup and temperature experienced by this fuel element, the stainless steel- $\mathrm{UO}_{2}$ fuel matrix exhibited very little radiation damage. The element design is also apparently satisfactory since major distortions or other defects were not found.

\section{REFERENCES}

(1) Armenoff, C. T., and Binstock, M. H., "Fuel Elements for the Organic Moderated Reactor Experiment", NAA-SR-1934 (December 15, 1957)。

(2) "Annual Technical Report on AEC Unclassified Programs, January-December, 1957", NAA-SR-2400, Part I (March 15, 1958).

(3) Crouthamel, C. E., and Johnson, C. E., "Spectrophotometric Determination of Uranium by Thiocyanate Method in Acetone Medium", Anal. Chem., 24, 1780 (1952).

(4) Glendenin, L. E., and Nelson, C. M., National Nuclear Energy Series, Vol 9, p. 1642 .

RJB: JEG/mar 
APPENDIX A

CASK-HANDLING METHODS 
• 
APPENDIX A

CASK-HANDLING METHODS

Element OMRE-3 arrived by commercial motor carrier at Battelle on July 7 , 1958. During transit the element was immersed in diphenyl to provide a medium for transfer of the heat generated by radioactive decay. The diphenyl was cooled by a recirculating water-cooling system mounted on the trailer with the shipping cask. Upon arrival of the cask at Battelle, the recirculating water system was disconnected and a tap water supply connected. The transfer from one system to the other required approximately $15 \mathrm{~m}$ in during which time the cooling water in the cask was stagnant. The initial volume of water expelled from the cask after the tap water supply was connected was not detectably warm to the touch.

During the storage period before the cask opening, a minimum of $50 \mathrm{gal}$ per hr of tap water flowed through the cooling coils in the cask. Periodic measurements with a mercury thermometer indicated no perceptible increase in the temperature of the water as it flowed through the cask.

On the day before the scheduled cask unloading July 21, 1958, the cooling-water supply was removed and approximately 14 gal of the water in the cask allowed to remain stagnant for a 16-hr period. At the end of this time, the water was expelled and collected. The temperature had increased $15 \mathrm{~F}$. This was taken to indicate that extreme precautions would be unnecessary to prevent excessive temperatures of the fuel element during its examination.

The front of the cask was elevated until the cask was almost vertical. Stopcocks at either end were opened to allow the diphenyl to drain from the annulus around the element. An estimated 3 gal were drained in a 6 -hr period. To hasten the flow, a positive pressure of approximately $2 \mathrm{~atm}$ was produced in the top of the cask using bottled acetylene. Qualitative measurements with a $G-M$ tube indicated that the diphenyl was free of radioactive contamination. When the annulus was apparently empty the cask was lowered into the horizontal position and prepared for moving into the cell.

The front end of the cask was placed on two, 4-1/2-ton-capacity Multi-Ton Rollers while the back end of the cask was supported by a 5-ton-capacity fork lift truck. The cask was then covered with polyethylene sheeting as shown in Figure A-1. The cask was moved into the hot cell; the ends blocked up, and the fork lift truck removed.

Equipment was placed in the cell to aid in the unloading as shown in Figure A-2. The drive mechanism for operation of the cask shutter, or lid, was connected through the cell wall with universal joints.

The cask opening was initiated on July 22, 1958. When the end shutter was approximately one-third open, the opening mechanism ceased to function and the shutter could not be moved in either direction. The difficulty was caused by a malfunction of the thrust bearing on the shutter-opening mechanism. Repairs were made in the cell and after a delay of about $24 \mathrm{hr}$ the cask was opened and the element removed. 


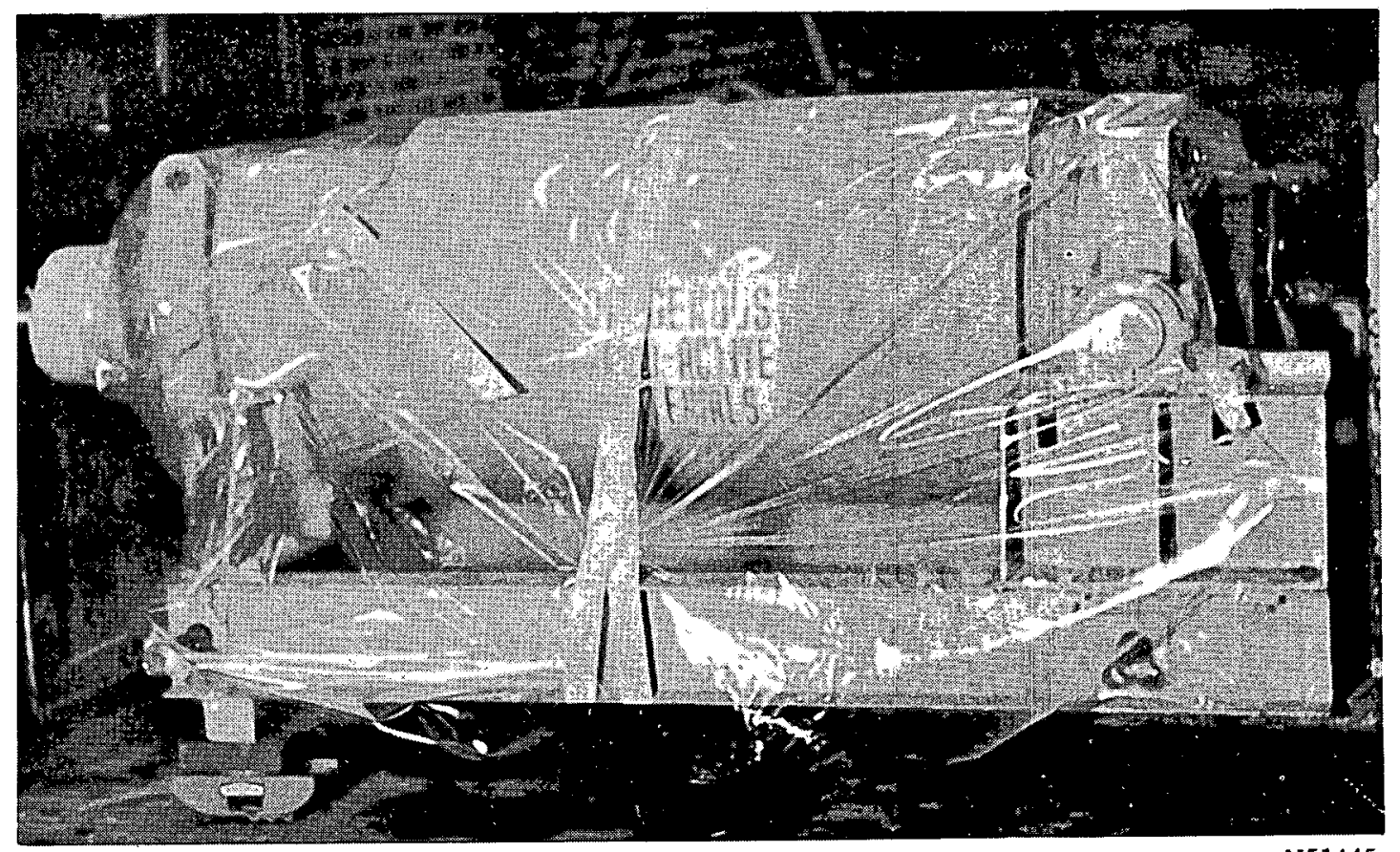

N51445

FIGURE A-1. CASK CONTAINING ELEMENT OMRE-3 READY TO BE MOVED INTO THE HOT CELL

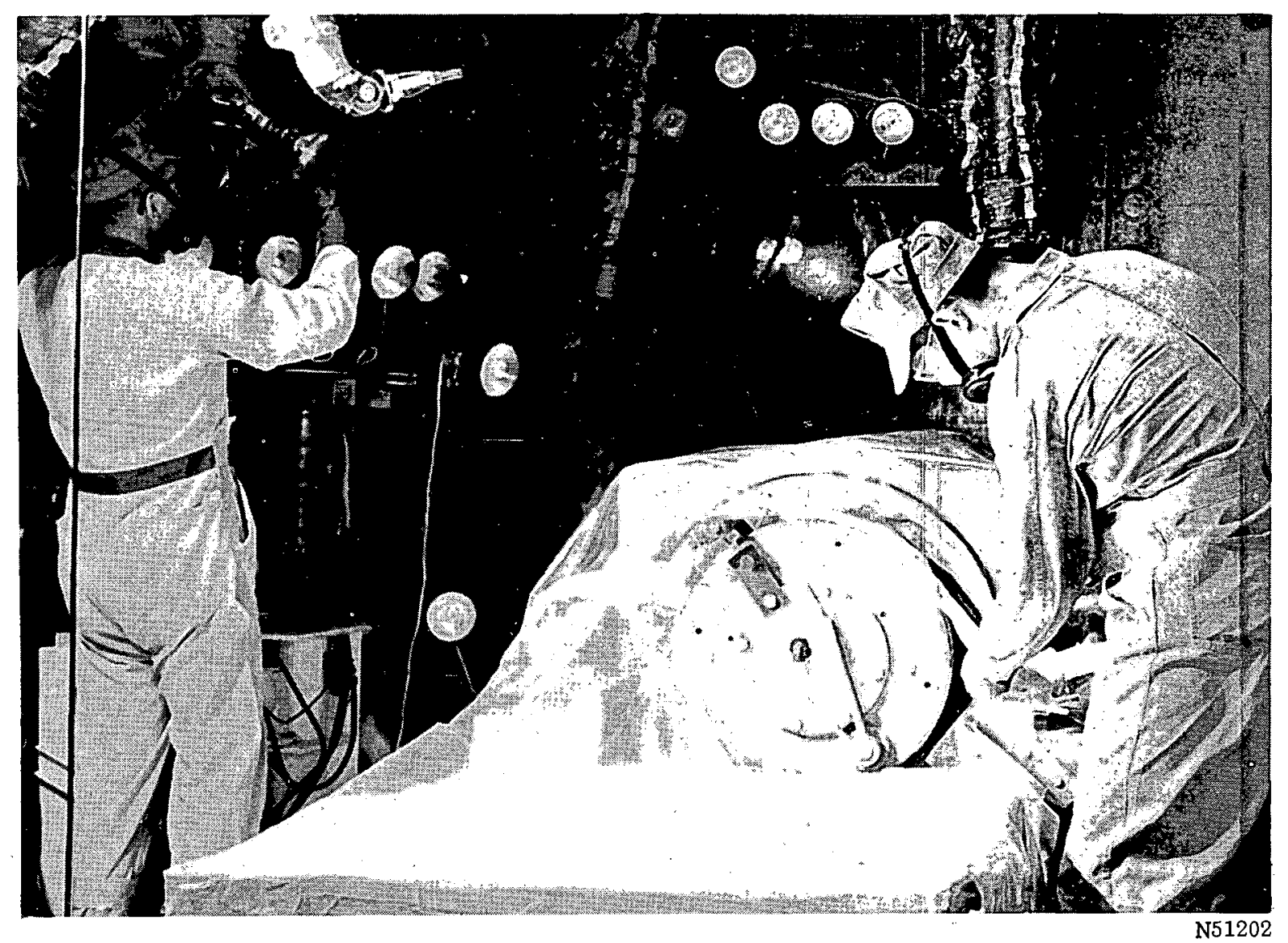

FIGURE A-2. CASK IN HOT CELL BEING PREPARED FOR OPENING 
APPENDIX B

TEMPERATURE MEASUREMENTS OF THE FUEL-ELEMENTBOX ASSEMBLY AND THE FUEL PLATES 
0

0. 
TEMPERATURE MEASUREMENTS OF THE FUEL-ELEMENTBOX ASSEMBLY AND THE FUEL PLATES

When Element OMRE-3 emerged from the shipping cask it was wet with the organic coolant. The coolant evaporated rapidly from the center portions of the element box and wisps of vapor were observed issuing from the elevated end of the element. Temperature measurements were begun immediately to ascertain the danger of overheating of the fuel plates.

The first element-box-surface temperature was taken $15 \mathrm{~min}$ after the element was removed from the cask. A thermocouple pressed to the side of the fuel-box assembly at approximately midlength recorded a temperature of $150 \mathrm{~F}$. A free-convection air temperature of $113 \mathrm{~F}$ was measured by holding the thermocouple in the elevated bottom end of the fuel element near the fuel plates. When air was forced over the plates from the top toward the bottom end of the element, the temperature of the exit air rapidly rose to $149 \mathrm{~F}$ and then dropped to $113 \mathrm{~F}$. After the element had been handled in the cell for $3 \mathrm{hr}$, the procedure was repeated. The temperature rose from $113 \mathrm{~F}$ to $122 \mathrm{~F}$ and then fell back to $113 \mathrm{~F}$. The element was then placed in a brass canister for storage.

Earlier plans had called for storage of the element in the brass canister with essentially stagnant air surrounding the element. Due to the concern about possible overheating of the fuel plates, the canister was filled with water until approximately threefourths of the fueled length of the element was immersed. Water was used since adequate quantities of diphenyl were not immediately available. After 2 days of storage the temperature of the water was $54 \mathrm{C}$. Later measurements indicated that the water temperature remained near this value during storage.

Three days after the element was removed from the cask, the temperature of the fuel-box assembly was surveyed with Tempilstiks, small commercially available crayon-type materials of known melting points. Between the second and tenth tabs, counting from the bottom end of the fuel-element-box assembly, the temperature was greater than $150 \mathrm{~F}$, but less than $200 . \mathrm{F}^{*}$. The temperature of all other outside surface areas of the box assembly were in excess of $113 \mathrm{~F}$ but less than $150 \mathrm{~F}$.

Although the outer fuel-element-box temperatures were not excessive, it was necessary to attempt to measure the fuel-plate temperatures.

An attempt to measure the temperatures of the fuel-plate surfaces was made by inserting a thermocouple between the plates. The temperatures at approximately 18 , 24 , and $36 \mathrm{in.}$ from the bottom of the element were about 144, 147, and $156 \mathrm{~F}$, respectively. Even though it was difficult to keep the thermocouple junction in contact with the surface of the fuel plates, these data were considered to give an indication that the fuelplate temperatures were not excessive. Measurements of the fuel-plate temperatures made after disassembly of the element corroborated this finding.

\footnotetext{
* Tempilstiks have a quoted tolerance of \pm 1 per cent.
} 
Three weeks after the fuel element was removed from the shipping cask, the fuelelement-box assembly was milled apart and the sixteen fuel plates removed on about August 11, 1958. The temperatures of the plates, as measured with Tempilstiks, were generally found to be greater than $150 \mathrm{~F}$ and less than $200 \mathrm{~F}$ in the center third of the plates and between 113 and $150 \mathrm{~F}$ on the remaining end sections.

During the course of the examination of the fuel plates, it became necessary to store them for a 3-week period in a tight bundle in a lead shipping cask rather than underwater in the canister. This occurred about 6 weeks after the cask unloading. Because of the approximate low heat-generation rate, it was felt that no undue temperatures would be experienced in the bundle under these conditions. On September 3, 1958, after about 3 weeks of such storage, the bundle was removed from the cask and the temperature of a plate at the center was measured, using the Tempilstiks. Approximately $14 \mathrm{~min}$ was required to remove the bundle from the cask and position it on the work table. After the bundle was positioned, it was split open and the temperature measurement completed in about $15 \mathrm{sec}$. The temperature was found to be less than $238 \mathrm{~F}$ in the hottest region near the midlength of the fuel plate. 
APPENDIX C

REMOVAL OF CARBONACEOUS RESIDUE FROM THE FUEL-ELEMENT-BOX ASSEMBLY AND FUEL PLATES 
.

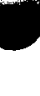

. 。 
$\mathrm{C}-1$ and $\mathrm{C}-2$

\section{APPENDIX C}

REMOVAL OF CARBONACEOUS RESIDUE FROM THE

FUEL-ELEMENT-BOX ASSEMBLY AND FUEL PLATES

Several different methods were used in attempted removal of the carbonaceous residue layer from the fuel-element-box assembly and the fuel plates. These included wiping and scrubbing with tissues and fiber brushes soaked in various solvents, flexing the plates in an effort to crack the layer, and buffing with a stainless steel wire wheel. The efforts to remove the residue from the exterior surfaces of the box assembly were confined to washing with an organic solvent.

Portions of the residue layer were successfully removed from two sides of the exterior surfaces of the fuel-element-box assembly, probably because the layer was partially removed during immersion in the diphenyl cask coolant. The se areas were cleaned by wiping the surfaces with tis sue soaked in trichloroethylene. The remainder of the residue on the box assembly failed to respond to this treatment or to scrubbing with fiber brushes soaked in trichloroethylene. Further attempts to clean the exterior surfaces were not made because of the difficulty and the fact that clean surfaces were not absolutely necessary for the examination. Although some residue was removed from the element box by washing with trichloroethylene, this technique did not remove any of the residue on the fuel plates themselves.

Many solvents were tried in an effort to remove the carbonaceous residue layer from the fuel plates. The solvents tried, all with little success, included trichloroethylene, carbon tetrachloride, acetone, benzine, trichlorobenzine, butyl alcohol, sodium hydroxide, 50 per cent nitric acid, and orthoxylene. In an unsuccessful effort to cause the residue layer to crack or chip, the plate was bent into a U-shape with approximately a $1-i n$. radius in the bend. Immersing the plate in liquid nitrogen in an attempt to cause the residue layer to crack or pull away from the plate was also unsuccessful. Buffing the plates with a fiber brush produced little success, and a fine stainless steel wire wheel was finally employed. This method was successful, and with careful use the wire wheel did not appear to extensively disturb the metal surface of the fuel plate. Even with this cleaning method, it was impractical to attempt to completely clean the fuel plates. 
$\bullet$ 
APPENDIX D

URANIUM BURNUP ANALYSIS 
• 
$\mathrm{D}-1$ and $\mathrm{D}-2$

APPENDIX D

URANIUM BURNUP ANALYSIS

The radiochemical determination of uranium burnup was based upon two postirradiation analyses, one for the fission-product cesium-137 and the other for nonfissioned uranium.

The fuel plates were punched to obtain 1/4-in. -diameter specimens for the analyses. These specimens were dissolved in a solution made up of approximately 2 parts nitric acid, I part hydrochloric acid, and 1 part water to produce a homogeneous liquid sample containing uranium, fission products, and the stainless steel constituents. Approximately $50 \mathrm{mg}$ of cesium carrier were added to the solution.

A volume aliquot of this solution was taken for uranium analysis. The uranium was extracted from an aluminum nitrate salted solution into diethyl ether by three contacts with fresh solvent. The distribution ratio for a single contact is about 20 in favor of the organic phase. Following extraction, the organic phases were combined and evaporated over $1 \mathrm{ml}$ of water in a steam bath. The aqueous residue was then rinsed into a volumetric flask and reagents added for spectrophotometric determination of uranium as the yellow thiocyanate complex in an acetone-water medium( ${ }^{(3)}$.

The analysis for cesium-137 was performed on an aliquot of the original specimen solution which had been diluted with 1 molar nitric acid to a point where a suitable amount of cesium-137 activity could be obtained. Duplicate aliquots were pipetted into $2 \mathrm{ml}$ of solution containing $20.0 \mathrm{mg}$ of nonradioactive cesium, as chloride, to act as carrier. The cesium was then separated by the perchlorate method as described by Glendenin(4). The final cesium perchlorate precipitate was filtered through a weighed glass-fiber filter circle, dried, weighed, and counted by an end-window flow-proportional counter. Similarly mounted cesium-137 standards were counted at the same time for counter calibration. (If cesium-134 is present, a correction is made by counting the sample in a gamma-ray spectrometer. The count rate of the sample above two energy level base lines is compared to the count rate of cesium-134 and cesium-137 standards under similar conditions. The cesium-134 contribution is subtracted algebraically. This method of correction is accurate to \pm 2 per cent.)

The counting data for cesium-137 were corrected by counter efficiency to disintegration rate; by dilution to disintegration rate in the original solution; by fission yield of 5.9 per cent and half-life of $30.0 \mathrm{yr}$ to fissions of uranium in the original solution. The number of uranium fissions was divided by the sum of the number of fissions and the number of uranium atoms present following irradiation to give the fractional uranium burnup. This value was multiplied by 100 to give the uranium burnup. This value can be converted to burnup based on a 33-yr half-life of cesium-137 by multiplying by 1.10 .

The cesium-137 standard was prepared from radiochemically pure cesium-137 obtained from ORNL and standardized by 4 pi beta counting. The uranium standard was prepared from chemically pure uranyl nitrate, precipitated and ignited to $\mathrm{U}_{3} \mathrm{O}_{8}$. The accuracy of the burnup analysis is \pm 13 per cent in units of standard deviation, the major portion of the uncertainty being due to the cesium-137 half-life, which is considered accurate to \pm 10 per cent.

(3) References at end of text of report. 
• 
APPENDIX E

METHOD OF EVALUATING AVERAGE FUEL-PLATE BURNUP 
- 


\section{APPENDIX E}

\section{METHOD OF EVALUATING AVERAGE FUEL-PLATE BURNUP}

Average values for the burnup of uranium in selected fuel plates from Element OMRE-3 were determined by making use of the gamma-activity curves obtained for these fuel plates. The average activity of a plate along the line of a gamma-activity scan was taken as the average ordinate of the gamma-activity curve. The average ordinate of each curve was obtained by measuring the area under the curve with a compensating polar planimeter and dividing this by the base length of the curve. The average burnup was then obtained by using the curve shown in Figure 41 in conjunction with the se calculated values of average gamma activity.

The average gamma activity of the entire fuel plate was calculated making use of the values of average gamma activity of each curve and equation derived below.

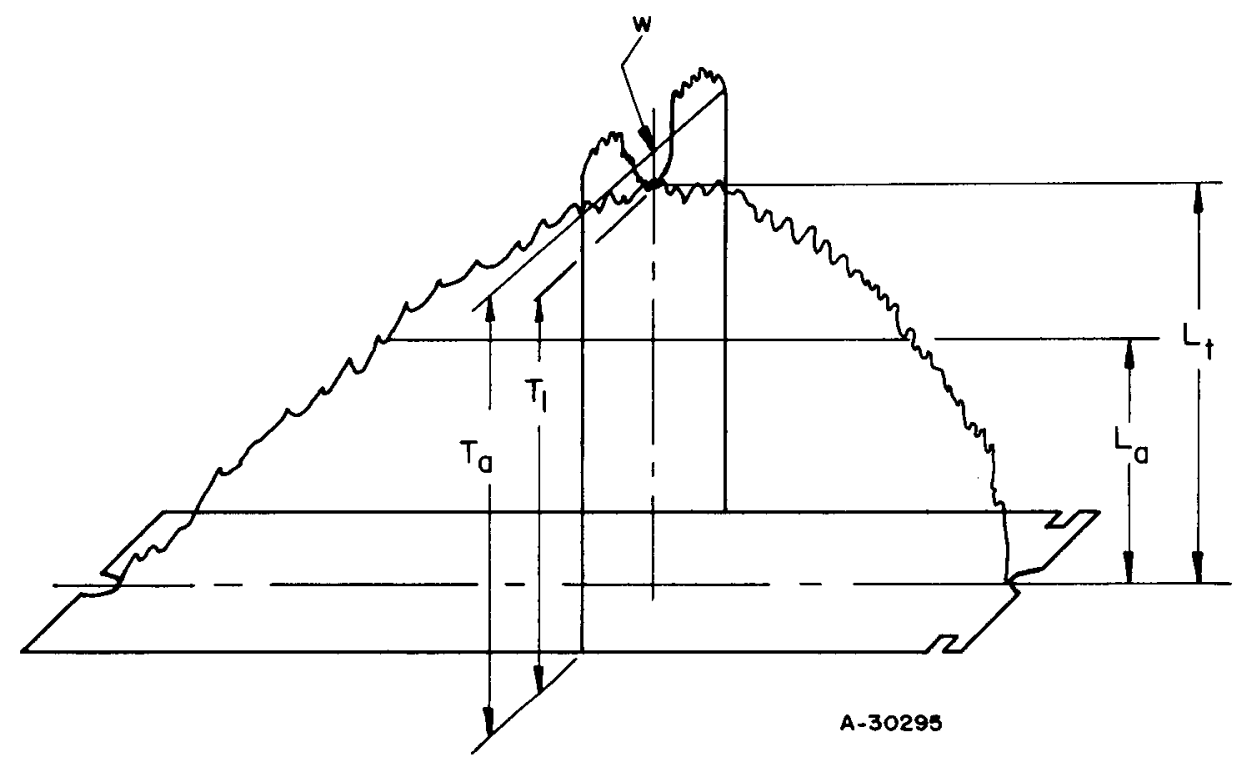

FIGURE E-1. TYPICAL LONGITUDINAL AND TRANSVERSE GAMMA-ACTIVITY CURVES IN POSITION ON A FUEL PLATE

\footnotetext{
Referring to Figure E-1,

$\mathrm{L}_{\mathrm{a}}=$ Average activity of longitudinal curve

$\mathrm{L}_{\mathrm{t}}=$ Activity of longitudinal curve at point where transverse curve crosses

$\mathrm{T}_{\mathrm{a}}=$ Average activity of transverse curve

$\mathrm{T}_{1}=$ Activity of transverse curve at point where longitudinal curve crosses.
} 
Inspection of the gamma-activity curves reveals that for all transverse curves of a given plate,

$$
\frac{\mathrm{T}_{\mathrm{a}}}{\mathrm{T}_{1}}=\text { constant. }
$$

However,

$$
\mathrm{T}_{1}=\mathrm{L}_{\mathrm{t}}
$$

and therefore

$$
\frac{\mathrm{T}_{\mathrm{a}}}{\mathrm{L}_{\mathrm{t}}}=\frac{\mathrm{T}_{\mathrm{a}}}{\mathrm{T}_{1}}=\text { constant. }
$$

A volume can be imagined formed by the locus of the line, w, over the length of the fuel plate with the fuel plate as a rectangular base. The average height of this volume, $\mathrm{H}_{\mathrm{a}}$, is the average total activity of the fuel plate. It can then be shown that

$$
\frac{\mathrm{H}_{\mathrm{a}}}{\mathrm{L}_{\mathrm{a}}}=\frac{\mathrm{T}_{\mathrm{a}}}{\mathrm{L}_{\mathrm{t}}} .
$$

Solving for the average total fuel-plate activity, the equation becomes

$$
\mathrm{H}_{\mathrm{a}}=\mathrm{L}_{\mathrm{a}} \frac{\mathrm{T}_{\mathrm{a}}}{\mathrm{T}_{1}}=\mathrm{L}_{\mathrm{a}} \times \text { constant. }
$$

This equation was employed in calculating the total fuel-plate activity of the three plates scanned. These activity values were then converted to uranium burnup with the aid of Figure 41. 